INTER NATIONAL MONETARY FUND

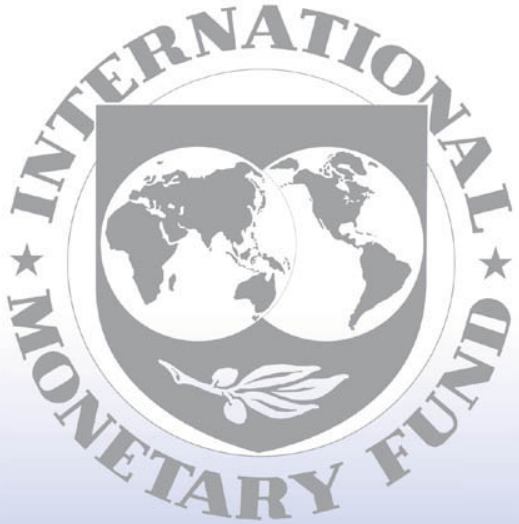

Staff

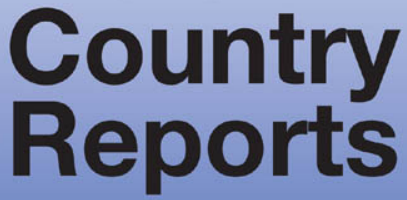




\title{
The Gambia: 2001 Article IV Consultation-Staff Report; Public Information Notice on the Executive Board Discussion; and Statement by the Authorities of The Gambia
}

Under Article IV of the IMF's Articles of Agreement, the IMF holds bilateral discussions with members, usually every year. In the context of the 2000 Article IV consultation with The Gambia, the following docaments have been releascd and are included in this package:

- the staff report for the 2000 Article IV consultation, prepared by a staff team of the MF, following discussions that enced on May 16, 2001, with the officials of The Gambia on economic developments and policies. Based on information available at the time of these discussions, the staff report was completed on June 29,2001 . The vicws cxpressed in the staff report are those of the staff team and do not necessarily reflect the views of the Executive Board of the IMF.

- a Public Information Notice (PNN), which summarizes the views of the Executive Board as expressed during its July 13, 2001, discussion of the staff report that concluded the Article IV consultation.

- a statement by the authorities of The Gambia.

The document(s) listed below have been or will be separately released.

Letter of Intent by the authorities of the member country*

Technical Memorandum of Understanding*

* May also be included in Staff Report.

The policy of publication of staff reports and other documents by the IMF allows for the deletion of market-sensitive information.

To assist the IMF in evaluating the publication policy, reader comments are invited and may be sent by e-mail to Publicationpolicy@imf.org.

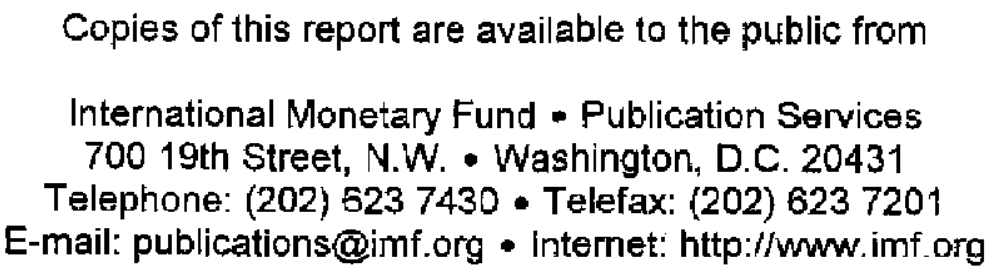

Price: $\$ 15.00$ a copy

\author{
International Monetary Fund \\ Washington, D.C.
}




\title{
INTERNATIONAL MONETARY FUND
}

\author{
THE GAMBIA
}

\section{Staff Report for the 2001 Article IV Consultation, First Review Under the Third Annual Arrangement Under the Poverty Reduction and Growth Facility and Request for Waiver of Performance Criteria}

Prepared by the African Department

(In consultation with the Fiscal Affairs, Legal, Monetary and Exchange Affairs,

Policy Development and Review, Statistics, and Treasurer's Departments)

Approved by Amor Tahari and Mark Allen

June 29,2001

Contents

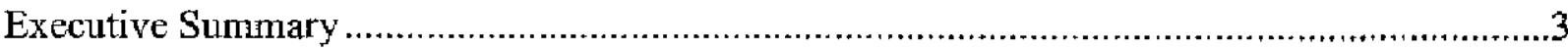

I. Introduction .

II. Recent Economic Developments and Performance Under the Program .........................6

III. Policy Discussions and Program for the Balance of 2001 ........................................11

A. Fiscal Policy .................................................................................................12

B. Monetary Policy and Financial Sector Reforms .......................................................14

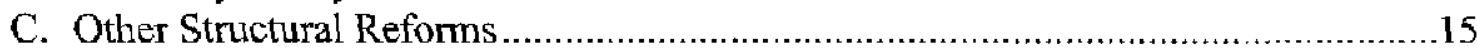

D. External Policies and Balance of Payments Outlook.............................................16

IV. The PRSP Process..............................................................................................21

Social Impact of the Program ................................................................................21

V. Technical Assistance and Statistical Issues ..........................................................23

VI. $\quad$ Prior Actions and Program Monitoring …................................................................23

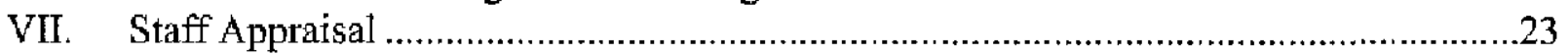

\section{$\underline{\text { Text Boxes }}$}

1. Settlement of the Gambia Groundnut Corporation's Dispute........................................

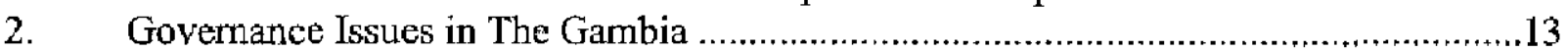

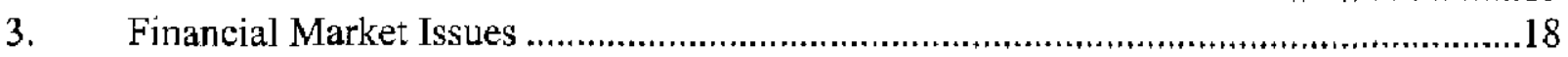

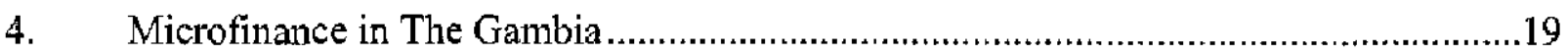

5. Structural Conditionality in the Third Annual PRGF Arrangement for The Gambia ....25 


\section{Figures}

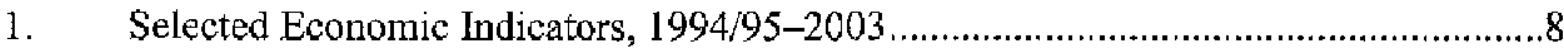

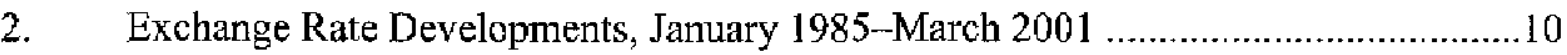

3. Spread Between Parallel and Interbank Market Rates, January 2000-March 2001 ....17

Tábless

1. Second and Third Annual Arrangements Under the Existing PRGF

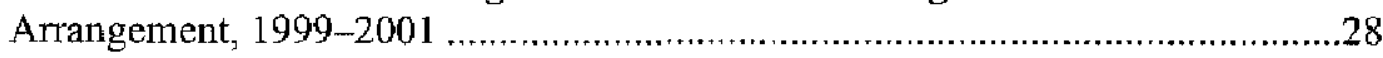

2. Fund Position During the Period of the PRGF Arrangement, 2000-01 .................29

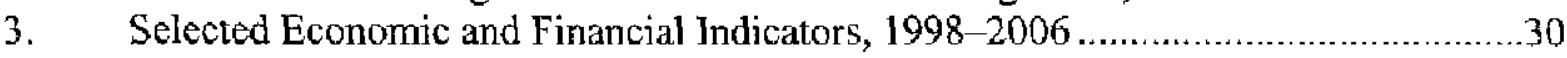

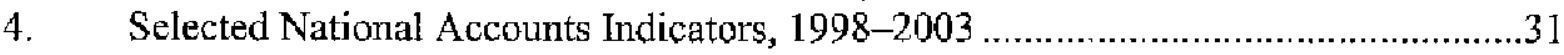

5. Central Government Financial Operations, 1998-2003 ......................................32

5a. Supplementary Budget for Allocation of HIPC Initiative Interim Debt Relief, 2001.34

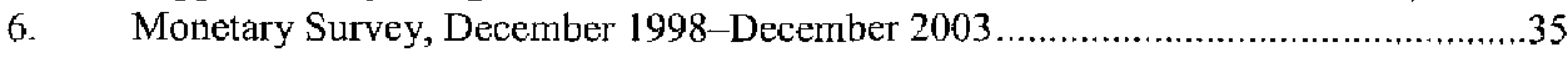

7. Summary Accounts of the Central Bank and Commercial Banks,

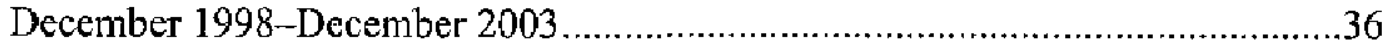

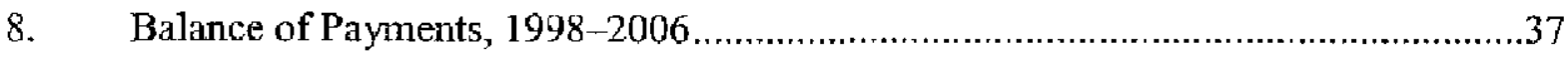

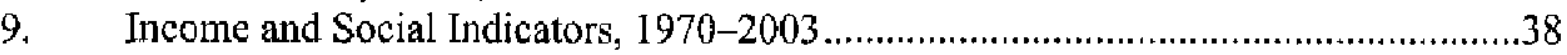

\section{Appendices}

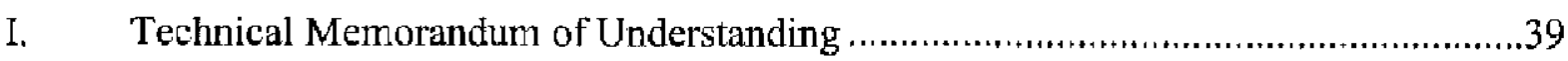

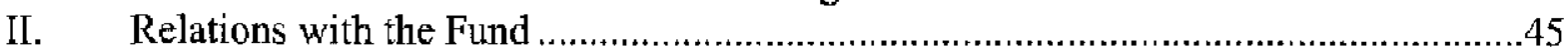

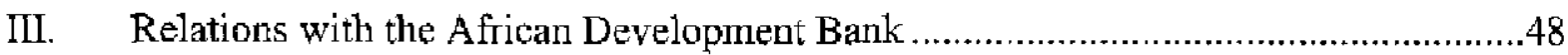

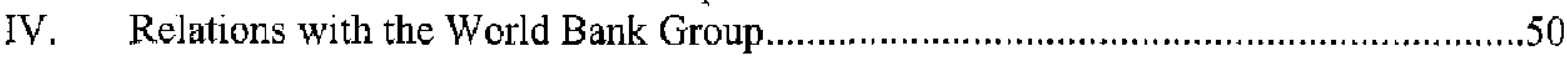

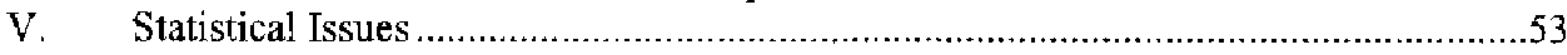




\section{EXECUTIVE SUMMARY}

\section{Recent economic developments and the revised program}

- Following discussions on the 2001 Article IV consultation and the first review under the third annual Poverty Reduction and Growth Facility (PRGF) arrangement, the authorities are seeking waivers for the nonobservance of a number of quantitative performance criteria. A second drawing in the amount of SDR 3.4 million (11 percent of quota) is subject to completion of the review.

- The local elections have been delayed and in turn donors have postponed the roundtable meeting originally scheduled for mid-2001 until after the elections.

- Performance under the program was mixed through March 2001. Despite GDP growth of 5.6 percent in 2000 and low inflation, there were slippages in the fiscal area through the first quarter of 2001. The overall fiscal deficit (excluding grants) was reduced to 3.6 percent of GDP in 2000 from 4.8 percent in 2000 as a shortfall in customs revenue and excess recurrent expenditure were offset by lower development expenditure. Broad money grew by 35 percent in 2000 , while the external current account deficit widened to 12 percent of GDP. During the first quarter of 2001 , accelerated payments to Alimenta (a Swiss private company whose property was seized by the government in early 1999), a payment to commercial banks for averdue crop financing loans, and continued weak customs receipts contributed to nonobservance of four end-March 2001 quantitative performance criteria.

- Outstanding governance issues include Alimenta's withdrawal of the property dispute with the government from international arbitration. A final payment due at end-July 2001 will trigger the privatization of Alimenta's former assets and related groundnut marketing reforms. The UN consulted the Fund in preparing an Integrated Preventive Strategy to assist The Gambia in dealing with a sizable refugee problem and to help strengthen the weakened democratic and economic institutions.

- In 2001, real GDP growth is projected at 5.7 percent, while inflation is expected to increase to $3 \frac{3 / 4}{4}$ percent. The fiscal deficit (excluding grants) is projected at about 4 percent of GDP and takes into account corrective measures to increase domestic petroleum product prices and to strengthen the customs department. The revised budget also reflects higher domestic interest payments, the cost for planned local and national elections, and lower development expenditure. Broad money growth will be reduced to 8 percent, while the external current account deficit is projected to narrow to $11^{3 / 4}$ percent of GDP with the expected recovery of exports and reexports.

- There were delays in implementing some structural reforms. However, progress was made in introducing an accounting framework to track poverty-reducing expenditure, including expenditure funded from HIPC resources, as a delayed fulfillment of the structural performance criterion for end-December 2000 . With 
technical assistance from the Fund and donors, momentum has been regained with respect to other structural measures and reforms, including the closing of the government accounts for 1992-97. A full PRSP is expected by end-2001.

\section{Issues highlighted in the staff appraisal}

- The appraisal notes the mixed performance in 2000 through the first quarter of 2001 and the authorities' response with corrective measures, including improved implementation of structural reforms.

- The staff urges the authorities to continue to strengthen budgetary implementation in order to reduce the overall deficit and stock of government domestic debt to sustainable levels. It also urges the authorities to pursue a prudent monetary policy while consolidating and deepening reforms in the financial sector.

- The authorities are further encouraged to consolidate and broaden other structural reforms in order to promote an environment conducive to private sector activity and a sustainable reduction in poverty. Noting progress made in the PRSP process and in data compilation, the staff urges the authorities to adhere to the end-2001 target to complete the full PRSP, and continue to improve the timeliness and quality of data.

- On the basis of broadly encouraging economic and financial developments and the strength of the revised program for the balance of 2001 , the staff recommends that the Executive Board approve the authorities' request for waivers for the nonobservance of four quantitative performance criteria and one structural performance criterion, and the completion of the first review under the third anmual PRGF arrangement. 


\section{INTRODUCTION}

1. Discussions for the 2001 Article IV consultation and the first review of the economic program supported by the third annual arrangement under the PRGF were held in Banjul during the period May 2-16, 2001. 'The Gambia's request for a three-year arrangement under the PRGF, in an amount equivalent to SDR 20.6 million (66.3 percent of the new quota), together with the first annual arrangement thereunder, in an amount equivalent to SDR 6.87 million (22.1 percent of quota) were approved by the Executive Board on June 29, 1998 (EBS/98/102, sup. 1;6/30/98). However, the first review under the first annual PRGF arrangement could not be completed because of slippages in implementing the budget and structural reforms. Moreover, there were governance problems arising from the government's seizure of the property of the Gambia Groundnut Corporation (GGC)-a private marketing monopoly owned by Alimenta. Performance under the second annual PRGF arrangement-approved by the Executive Board on November 19, 1999-was satisfactory: the Board granted waivers for the nonobservance of three end-March 2000 quantitative performance criteria, while the authorities met all of the end-September 2000 quantitative performance criteria. The Executive Board approved the third annual arrangement on December 11, 2000 for the period October 1,2000-September 30, 2001, in the amount of SDR 10.3 million (33.1 percent of quota). ${ }^{2}$ SDR 3.4 million was disbursed upon Board approval of the arrangement, and the second disbursement (SDR 3.4 million) will become available subject to the observance of the end-March 2001 quantitative performance criteria and the structural performance criterion for end-December 2000 , and the completion of the first review. If the full amount under the third annual PRGF arrangement is disbursed, and taking into account scheduled repayments, The Gambia's use of Fund resources would rise from 44.8 percent of quota at end-2000 to about 66.3 percent at end-2001 (Tables 1 and 2).

2. In the attached letter to the Managing Director dated June 29, 2001 (Appendix 1), the government of The Gambia outlines economic and financial policies for the balance of 2001 and requests waivers for the nonobservance of the end-March 2001 quantitative performance criteria with respect to (a) net bank credit to the central government; (b) net domestic assets of the central bank; (c) the basic primary balance of the central government; and (d) the floor

${ }^{1}$ The Gambian representatives included the Hon. F. Jatta, Secretary of State for Finance and Economic Affairs (DOSFEA), Mr. M. C. Bajo, Governor of the Central Bank of The Gambia (CBG), other secretaries of state, and senior public officials. President Yahya Jammeh and Vice President Isatou Njie-Saidy received the mission. Discussions were also held with representatives of the donor community, the private sector, and the Independent Electoral Commission (IEC). The mission comprised Mr. Kibuka (Head), Mr. Tjirongo, Mr. Xiao, and Ms. Brogan (Assistant) (all AFR), and Mr. Schneider (PDR). Parallel Fund technical assistance and World Bank missions were also in the field.

${ }^{2}$ This includes SDR 1.718 million that was rephased from the drawings under the second annual arrangement, since the latter had expired before the completion of the second review. 
on the net official international reserves. A waiver is also being requested for the nonobservance of the end-December 2000 structural performance criterion to establish a comprehensive accounting framework to monitor poverty-reducing expenditure, including expenditure funded from debt relief under the enhanced HIPC Initiative.

3. In concluding the 2000 Article IV consultation discussions on July 19,2000 , Executive Directors noted the broadly encouraging results on the macroeconomic front, notwithstanding the request for waivers for the nonobservance of some of the end-March 2000 performance criteria. They urged the authorities to continue strengthening fiscal performance, improving governance, and implementing further structural reforms.

4. In November 2000, the Executive Boards of the World Bank and the Fund discussed the enhanced HIPC Initiative preliminary document for The Gambia (EBS/00/208; 10/25/00) and agreed that the country qualified for assistance under the Initiative. The Fund Executive Board discussed the enhanced HIPC Initiative decision point document (EBS/00/242; $11 / 28 / 00)$, the interim poverty reduction strategy paper (L-PRSP) (EBD/00/99; 11/28/00), and the joint staff assessment (JSA) of the I-PRSP (EBD/00/100; 11/28/00), concurrently with the request for the third annual PRGF arrangement.

5. In 1993, The Gambia accepted the obligations under Article VIII, Sections $2(a), 3$, and 4 of the Fund's Articles of Agreement, and maintains an exchange system that is free of restrictions on payments and transfers for current transactions. Summaries of The Gambia's relations with the Fund and the World Bank Group are contained in Appendices II and IV, respectively. Outstanding statistical issues are discussed in Appendix V.

\section{Recent Economic Developments and Performance Under the Program ${ }^{3}$}

\section{During 2000, economic performance was mixed, with strong GDP growth and} moderation of inflation; however, there were some slippages in the fiscal area. Preliminary data indicate that real GDP grew at 53/4 percent in 2000 , as good rains boosted the production of groundnuts and other crops. The good harvest in 2000 contributed to a further moderation in inflation to about 1 percent (based on the low-income consumer price index-CPI) for the year (Figure 1 and Table 3).

\section{The overall fiscal deficit (excluding grants) was reduced to about 3.6 percent of} GDP in 2000 from $43 / 4$ percent in 1999. A shortfall in customs receipts, and a slight overrun in expenditure (mostly wages and other recurrent expenditures) were largely offset by shortfalls in capital expenditure because of lower external project financing. The resulting larger-than-programmed deficit (in dalasi tenms), in addition to the overpayment of the first

\footnotetext{
${ }^{3}$ Details of developments during 2000 through the first quarter of 2001 can be found in EBS/00/241 (11/28/00), which was discussed by the Executive Board on December 11, 2000, and in the letter of intent.
} 
installment to Alimenta (see Box 1), ${ }^{4}$ contributed to an increase in net govemment domestic bank borrowing in excess of the program level. Government domestic debt increased to about 31 percent of GDP at end-2000, up from 27 percent at end-1999.

8. During the first quarter of 2001, there were slippages in the implementation of the budget. In February, the government paid D 64.5 million (1.1 percent of GDP) to three commercial banks for nonperforming loans that had financed the 2000 groundnut crop. ${ }^{5}$ In addition, the authorities also made an unscheduled payment to Alimenta in February 200I, which facilitated the company's withdrawal of the dispute from arbitration.

9. During 2000, broad money grew by 35 percent, considerably above the program target, reflecting intervention by the CBG in the foreign exchange market (see para. 10 below). Reserve money, mainly currency outside banks, also exceeded the program target. The treasury bill rate declined from 12.5 percent in December 1999 to 12 percent by December 2000 . Reflecting mainly the fiscal slippages, the quantitative performance criteria for end-March 2001 with respect to (a) net bank credit to the central government; (b) net domestic assets of the central bank; and (c) the basic primary balance of the central government were not observed (Appendix Table 1).

10. In the external sector, preliminary data indicate that the current account deficit (excluding official transfers) increased to 12 percent of GDP in 2000 from $11 \frac{1}{2}$ percent in 1999 , as imports recovered from the adverse impact of the preshipment inspection scheme (rescinded in July 2000) while reexports were slowed by cross-border difficulties. However, gross international reserves increased above the target for end-2000 because of central bank's efforts to build up reserves ahead of the end-December payment to Alimenta, given the then uncertain receipt of the EU grant. This action contributed to a depreciation of the dalasi by 4.8 percent in real effective terms in 2000 (Figure 2); following a similar depreciation of 2 percent on average during 1998-99 in the last quarter of 1999 , thus, continuing the recent trend toward enhanced external competitiveness of The Gambia. However, the end-March 2001 quantitative performance criterion with respect to the floor on the net official international reserves was not observed, as the CBG accelerated payments to Alimenta and

\footnotetext{
${ }^{4}$ The European Union (EU) and the government originally intended to use a $€ 5$ million grant to reduce government domestic debt. Instead, the entire grant was paid to Alimenta in order to encourage the company to withdraw the case from arbitration by the International Center for Settlement of Investment Disputes (ICSID), as well as to reduce the interest and other charges on outstanding debt balances; under the settlement agreement, interest is payable on any outstanding balances as from January 1, 2001. Moreover, such balances require a bank guarantec.

${ }^{5}$ A one-off amortization of loans guaranteed by the CBG, following the Alimenta incident in 1999 that had discouraged the entry of new exporters. For details, see letter of intent.
} 
Figure 1. The Gambia: Selected Economic Indicators, 1994/95 - 2003 1/2/
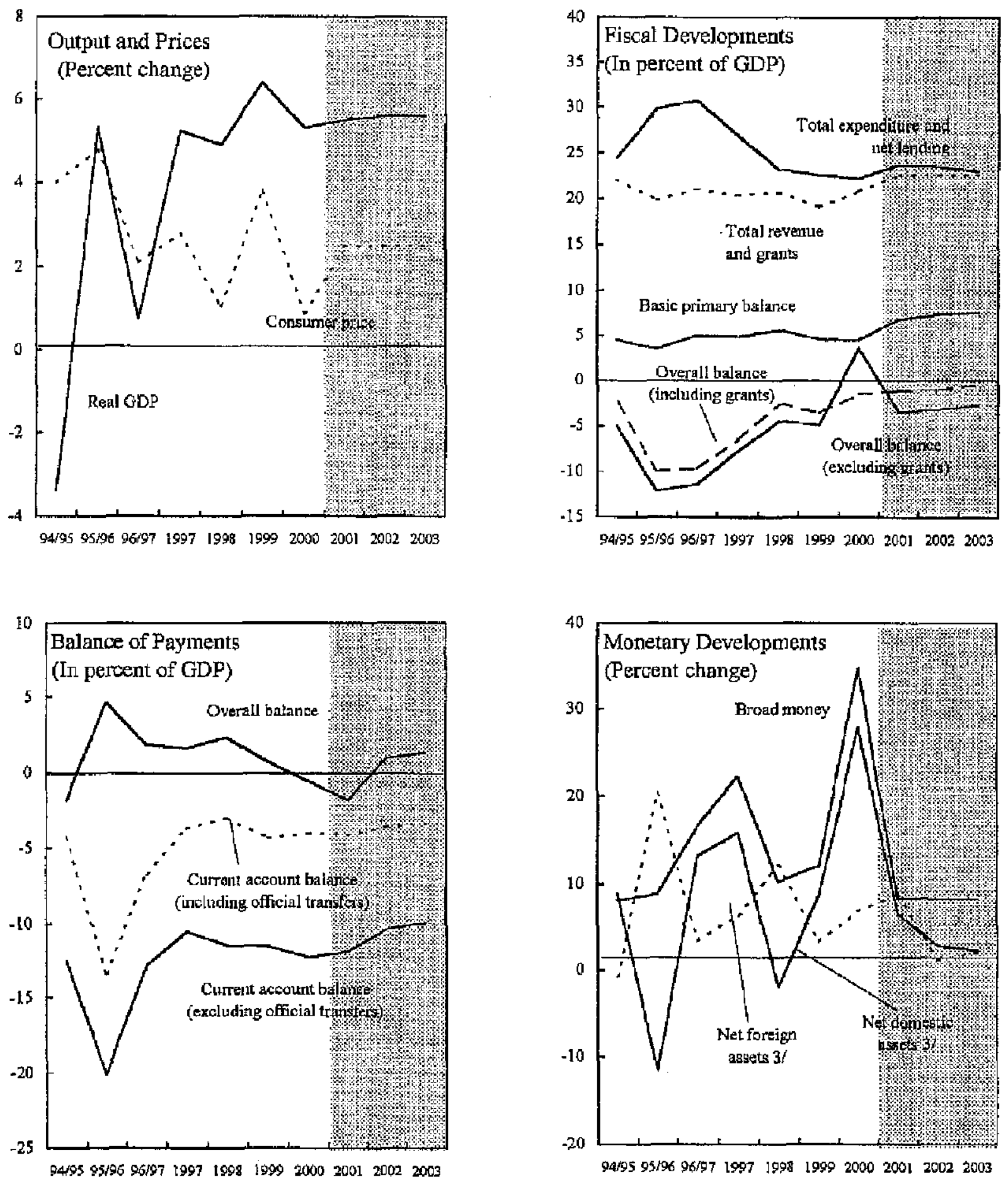

Sources: The Gambian authorities; and Fund staff estimates and projections.

1/ Until 1996/97, fiscal years (July-June); from 1997, calendar years.

2/ Shaded areas represent projections.

$3 /$ In percent of broad money at the begiming of the period. 


\section{Box 1. Settlement of the Gambia Groundnut Corporation's Dispute}

In January 1999, the government seized the property of the Gambia Groundnut Corporation (GGC)-a private company that had a monopoly in processing and exporting groundnuts - without compensation. Alimenta-the GGC's parent company - submitted the case to ICSID in July 1999, seeking compensation of US\$32 million. However, at the government's initiative, the two parties reached an out-of-court settlement in October 2000 , under which The Gambia would pay a total of US\$1 1.4 million to Alimenta by end-July 2001, as set out in the table below. The European Union (EU), the key donor supporting the groundnut sector, agreed with the government to use a grant of $€ 5$ million (originally expected in May 2000 but received in late December) to pay Alimenta instead of reducing domestic debt. Following the government's payment to it of USS6.5 million through February 2001 and an arrangement for a bank guarantee for the balance, Alimenta withdrew the case from ICSID arbitration in March $200 \mathrm{I}$.

The final payment to Alimenta is due by end-July 2001, and the government expects to receive another grant of about $€ 4.5$ million from the EU toward this payment. When Alimenta has been paid in full, its properties, comprising two groundnut-processing plants and a number of barges, will revert to the government. The government, in turn, plans to privatize these assets to difforent marketing firms in order to increase competition and benefit farmers as part of broader reforms to improve the groundnut sector.

Government Payments to Alimenta, 2000-01

(In millions of U.S. dollars)

\begin{tabular}{lcc}
\hline & Schedule & Actual/Expected 1/ \\
\hline & & \\
December 2000 2/ & 3.428 & 4.653 \\
February 2001 & 0.000 & 1.849 \\
June 30, 2001 & 5.025 & 0.000 \\
July 31, 2001 & 2.968 & 4.998 \\
Total & 11.421 & 11.500 \\
Memorandisn item: & & \\
Payments through February 2001 & 3.428 & 6.502 \\
\hline
\end{tabular}

Sources: The Gambian authorities; and staff estimates.

1/ Partly based on conversions from euro into U.S. dollars at the prevailing

exchange rates. Total includes interest charges and other costs.

2/ The cxccss payments in December 2000 and March 2001 amounted to

D 18 million and D 49 million at the prevailing exchange rate, respectively.

sold a substantial amount of foreign exchange to address the buildup in demand. As of end2000 , the outstanding public external debt was SDR 321 million (100 percent of GDP).

11. The implementation of structural reforms was slower than expected, notably on account of a delay in completing the structural performance criterion for end-

December 2000 to establish and begin to implement an accounting framework to track poverty reduction expenditure. However, the performance criterion was fulfilled by end-May 2001 and as expected, additional measures are being taken to improve the implementation of 
Figure 2. The Gambia: Exchange Rate Developments, January 1985 - March 2001

(Indices, $1990=100$ )
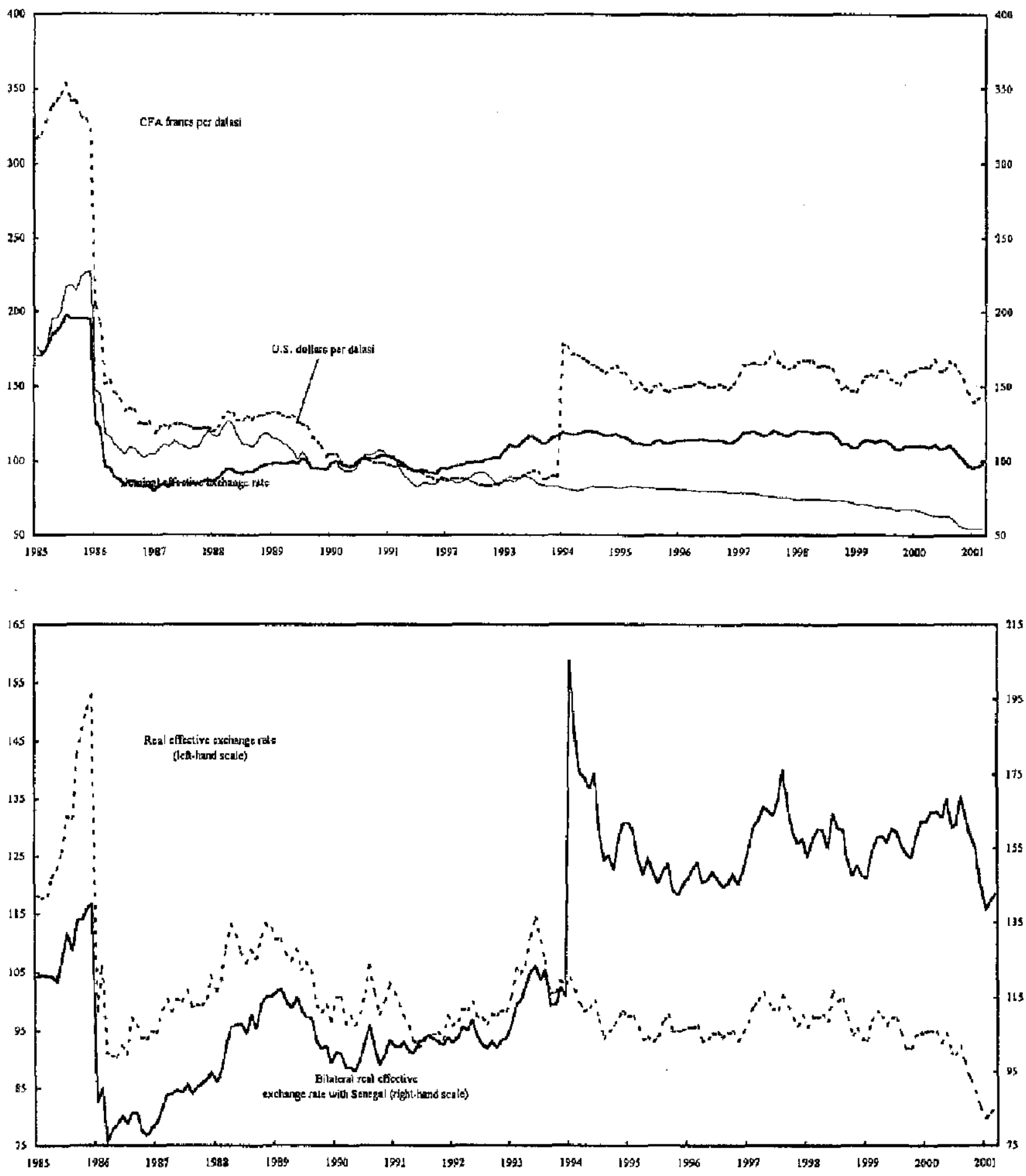

Source: IMF, Information Notice System. 
the framework. Meanwhile there have been delays in the provision of technical assistance by the United Nations Development Programme (UNDP), which slowed the implementation of structural benchmarks on measures to improve the compilation of the national accounts and the CPI. Fund technical assistance in April-May facilitated the planned implementation of structural benchmarks in the financial sector. The mission noted good progress in implementing the PRSP process (see below).

12. Governance and political issues, including the delay in local elections, the dismissal of some key officials, and proposals to amend the constitution, have caused concem among donors, who have postponed the roundtable meeting (originally scheduled for mid-2001 as part of the PRSP process) until after the elections which are slated for October 2001 and early 2002. In response to letters from the authorities in April on governance issues, including Alimenta, the Managing Director commended the authorities on progress in addressing the Alimenta dispute and urged them to redouble their efforts in addressing the outstanding issues. The UN sent a mission to Banjul and has prepared an Integrated Preventive Strategy to assist in strengthening governance in The Gambia (see Box 2).

\section{Policy Discussions and Program for the Balance of 20016}

13. The discussions took place against the background of (a) the tension in policies between efforts to complete payments to Alimenta and containing the large domestic debt. In particular, the authorities were concerned by the implications of the donors' postponement of a roundtable meeting to close an estimated financing gap (SDR 5.9 million) in 2001; (b) an urgent need for the authorities to strengthen institutional capacity in support of the PRSP and HIPC Initiative process; and (c) a need to address governance issues, particularly the pending groundnut marketing reforms - including the proposed privatization of the Alimenta assetsand timely preparation for local and national elections by early 2002 . Thus, the discussions, which focused on assessing recent economic and financial developments, took these issues into account in framing macroeconomic and structural policies for the remainder of 2001 broadly consistent with the objectives set out in the memorandum on economic and financial policies for 2000-01 (EBS/00/241, App. 1; 11/28/00) and the I-PRSP.

14. For 2001, real GDP growth is projected at 5\%/4 percent, owing to expected continued improvement in agricultural production, particularly groundnuts, through the expected marketing reforms. Reexport trade and tourism are also expected to continue recovering from adverse developments in 2000 . Measured inflation is projected to increase to $31 / 2$ percent by end-2001, reflecting the continued depreciation of the dalasi and the increase in domestic petroleum product prices (see below).

\footnotetext{
${ }^{6}$ For details of the measures for the balance of 2001, see Appendix 1.
} 


\section{A. Fiscal Policy}

15. The fiscal program for 2001 was revised to take account of recent developments, resulting in a higher overall deficit (excluding grants) of 3.9 percent of GDP (3 $1 / 2$ percent in the original program). However, the deficit (including grants) is virtually unchanged at about 1 percent of GDP. With the incorporation of expenditure expected to be funded from HIPC Initiative debt relief, the deficit (excluding grants) will reach 5 percent of GDP (see below). To finance the deficit, the govemment will make further recourse to domestic bank and nonbank financing, although domestic debt will decline to 27.8 percent of GDP by end2001 , compared with the 24.6 percent envisaged earlier. The authorities explained that they had no choice but to address the unfortunate developments related to the seizure of the Alimenta property and crop financing that had delayed their strategy to substantially reduce domestic debt. They expressed confidence that they would be moving forward with reforms to prevent a recurrence of direct government involvement in the groundnut sector. The staff stressed that it was critical that the proposed reforms be implemented fully and expeditiously.

16. In March 2001, revenue measures implemented to address the weaker-thanenvisaged customs receipts, comprised higher gasoline (an increase of 9 percent) and diesel and ketosene prices ( 15 percent each), the curtailment of customs duty exemptions, and the collection of tax arrears. Other revenue will increase as a result of better performance by income tax receipts, and the recovery of funds (from the EU compensation and exporters) related to 1999/2000 crop financing operations, and the budget would benefit from increased grants. Measures were also taken to implement the delayed automated system of customs data (ASYCUDA). Further strengthening of the revenue departments, including the implementation of ASYCUDA II (which will provide computer links among the port, the airport, and regional posts in order to improve tax administration and data compilation), will be supported by the proposed World Bank Capacity-Building and Economic Management Project.

17. On the expenditure side, the 2001 budget was modified to include (a) higher domestic interest payments of about D 60 million (1 percent of GDP); (b) funding of D 8.4 million, for the local and presidential elections likely in October 2001 and for the parliamentary elections likely in January 2002; (c) government payments to the three commercial banks; and (d) the 2001 contingency budget funded from the US\$4.4 million (D 68 million) provided by the Fund, the World Bank, and the African Development Fund/Bank as interim debt relief under the enhanced HIPC Initiative, which was submitted to parliament on June 14,2001 as a program prior action (see Table $5 \mathrm{~b}$ ). Parliament approved the budget - as a supplementary appropriation-on June 25. Moreover, the budget, as before, reflects the final payment to Alimenta. Overall, recurrent expenditure in 2001 will increase by 3.3 percent of GDP, compared with the original program, but this will be partly offset by lower development expenditure now estimated at about 5 percent of GDP compared with about 41/2 percent recorded in 2000 (Table 5). 


\section{Box 2. Governance Issues in The Gambia}

The deteriorating state of governance in The Gambia has continued to draw the attention of the international donor community during 2000-01. In early 2001, several donors made representations to the authorities on a namber of governance issues. Moreover, in November 2000, the UN sent a mission to Banjul to evaluate the governance issues and regional instability.

The UN mission noted with concem the current risk level in The Gambia, which had the pctential for a sudden and sharp deterioration in the political situation, and hightighted the following: (a) The Gambia, being relatively stable in a subregion with ever-widening armed conflict had taken a disproportionate share of immigrants $(15,000$ registered refugees and about 500,000 nonregistered migrants); (b) instability among the youth (below age 25), who account for over 60 percent of the total population-against the background of deepening poverty, declining foreign assistance, and limited opportunities for higher studies-was contributing to high youth unemployment as some of the youth had turned to a disruptive life of criminal behavior, including serving as mercenaries in regional conflicts, as drug and arms traffickers, and many were susceptible to HIV/AIDS; (c) intolerance was growing as segments of society blamed the country's economic misfortumes on foreigners, including refugees; and (d) regional instability added to internal pressures, not only from the high number of migrants and refugees that The Gambia harbored, but also from the increased risk of a spillover of violence and the uncontrolled circulation of small arms and illicit dnigs.

Against this background, the UN has proposed to implement an Integrated Preventive Strategy to enable The Gambia to respond better to the multiple and interrelated nature of the challenges the country faces. The multisectoral strategy, to be implemented in close partnership with The Gambia and interested members of the international community, seeks to address a number of areas: poverty alleviation, sustainable development and the role of women; governance-including through electoral support; the combating of comption; refugee and hurnan rights issues; youth employment; environmental and health issues; and capacity building.

In response to the UN's request for inputs into the Integrated Preventive Strategy, the Fund recommended that economic support under the strategy should be integrated into the PRSP process. It also proposed a series of donor roundtable meetings that could include a special session on technical assistance to help brild the institutional capacity in The Gambia. The Fund committed itself to continuing to play a significant role through the PRGF-supported program in helping The Gambia consolidate the achievements it had made so far, in fiscal, financial, and exchange and trade rate policies, as well as in structural reforms, all within the context of the PRSP process.

Governance issues have been on the authorities' priotity agenda since the government adopted the Governance Policy in 1999, which with the assistance of UNDP-initiated a number of reforms aimed at establishing an overall policy framework for governance. It provides a comprehensive national program for establishing and strengthening democratic and adrrinistrative institutions and processes in The Gambia, and for enhancing public participation. The good governance and public administrative reform program (which is one of the program pillars in the interim PRSP) includes (a) reforming parliamentary structures and processes; (b) reviewing of constitutional and electoral processes to improve supervision of government activities; (c) promoting civic education to strengthen the capacity of local civic organizations; (d) reforming legal and judicial processes to introduce flexible mechanisms for ensuring access to justice; (e) decentralizing the local government system to promote community participation and improve the delivery of development services to communities; and ( $f$ ) reforming public management and administration.

The UN Integrated Preventive Strategy, which calls for electoral support and institutional capacity building, among other objectives, would enhance the government's efforts in implementing the governance program, which has hitherto moved slowly. Accordingly, resource mobilization through a weil-promoted series of strategically placed donor roundtable meetings-devoted also to technical assistance issues and the PRSP process-could help to address the multiple problems faced by The Gambia and help reduce the high risk levels. 
18. The Gambia has been identified as one of the HIPC Initiative countries in need of a substantial upgrading of the system for tracking poverty-reducing expenditure. Accordingly, the discussions on fiscal reforms focused on the broader issues of budget formulation and implementation. The authorities expressed their appreciation for Fund technical assistance in supporting budget reforms. They hope to continue relying on the resident Fund budget advisor to improve accounting practices and move toward a comprehensive reporting and control of government expenditure, especially on the belowthe-line (BTL) accounts. ${ }^{7}$ The advisor has also assisted in closing the government accounts for 1992-97 and as a follow-up, the Accountant and Auditor General's Offices are collaborating to complete the delayed audit of those accounts and expedite the auditing of future public accounts. The capacity-building project will also assist with (a) the computerization of the Accountant General's Office; (b) strengthening of the macroeconomic unit in DOSFEA; and (c), in conjunction with DFID, preparation of the public expenditure reviews (PERs) in three of the key sectors targeted in the I-PRSP (agriculture, education, and health), which also serve as a first step toward a medium-term expenditure framework (MTEF). As detailed in the letter of intent, the fiscal program for 2001 also incorporates the full repayment of civil service salary advances and the elimination of cross arrears between the government and the public enterprises by end-2001. The mission noted the ambitious scope of these reforms and urged perseverance and close coordination with the providers of technical assistance in implementing the entire package.

\section{B. Monetary Policy and Financial Sector Reforms}

19. Monetary policy during 2001 will seek to keep period-average inflation below 4 percent and maintain external reserves equivalent to about 5.3 months of imports. This will be underpinned by the prudent fiscal policies described above, which will permit a tight overall monetary policy while providing adequate credit to the private sector. Following slippages through early 2001 partly associated with accelerated payments to Alimenta and crop financing, the authorities have taken measures to tighten monetary policies in the remainder of 2001, contributing to an increase in velocity to 2.8. Broad money growth has already been reduced to 14 percent for the 12-month period ended March 2001, through central bank sales of foreign exchange and stepped up sales of securities toward the end of the quarter; the latter contributed to an increase in the treasury bill rate to 12.5 percent. The central bank will seek to moderate the growth of broad money from an estimated 35 percent during 2000 to 8 percent by end-2001 with the planned sales of securities. Consistent with the strategy outlined in the I-PRSP to give a substantial role to the private sector, credit for the latter is programmed to increase by about 23 percent for 2001 . This expansion will support increased private sector activity in the planned privatization of a number of public

\footnotetext{
${ }^{7}$ A fund technical assistance mission visited Banjul in June 2001, to review the work of the budget advisor and assess the public expenditure management system and the capacity for HIPC monitoring and prepare a draft action plan for improvements.
} 
enterprises, crop financing during the 2001/02 season, and an improved investor climate following the resolution of the Alimenta dispute.

20. With regard to the foreign exchange market, the central bank encouraged commercial banks to deal directly with the foreign exchange bureaus (the parallel market that transacts mainly in cash) and in the process helped to integrate the two markets. Moreover, during the first quarter of 2001, the CBG attempted to meet the pent-up demand for foreign exchange in the interbank market using competitive bids. ${ }^{8}$ As a result, the spread between the interbank and parallel rates declined from 14 percent in September 2000 to an average of 0.4 percent during the first quarter of 2001 (Figure 3 ). Complementary reforms to broaden the market and reduce foreign exchange transactions costs through the introduction of foreign currency deposits are discussed in Box 3.

\section{Financial sector reforms are being pursued at the regional, national, and micro} level in order to promote an efficient and competitive financial sector and a reduction in The Gambia's deep-seated poverty by supporting income-generating activities for the poor. The Gambia is participating in the Accra Declaration to establish a West African Monetary Zone (WAMZ) by 2003 though it is too early, at this stage, to assess its implications for economic policy for the country. Reforms at the national and micro levels are summarized in Boxes 3 and 4 , respectively.

\section{Other Structural Reforms}

22. As detailed in the attached letter of intent, the authorities are pursuing other structural reforms focused on (a) modernization of business-related legislation and regulation; (b) development of a competition policy; and (c) public enterprise divestiture. The latter reform will be aided by the recently approved Privatization Act. In 2001, up to D 20 million will be transferred from the divestiture account to reduce the government domestic debt.

\section{The authorities indicated that agricultural reforms would focus on upgrading} groundnut marketing, among other things, to prevent a recurrence of direct government intervention in crop financing. They commended the Fund and the EU for the support they had provided to expedite the resolution of the dispute with Alimenta, which could have dragged on and resulted in substantially larger costs. They expected to continue to work. closely with the EU and the Agri-Business Service Plan Association (ASPA) and press on with the privatization of Alimenta's assets to competing experienced operators, in order to promote private crop financing and higher producer prices. While welcoming the steps taken to date toward privatizing the Alimenta assets, the mission stressed the importance of full transparency in the privatization process. It also urged the authorities to follow up closely on

\footnotetext{
${ }^{8}$ Previously the CBG had sold foreign exchange at prevailing interbank rates.
} 
the recovery (from exporters) of the remaining balances from the $1999 / 2000$ groundnut marketing loans.

\section{External Policies and Balance of Payments Outlook}

24. The authorities felt that the recent significant further reduction and rationalization of the external tariff (from a maximum of 20 percent to 18 percent (the import-weighted average extemal tariff was reduced from 12 percent to 11.8 percent), along with the reduction of the number of tariff bands from ten to three, all effective August 2000 ) ${ }^{9}$ should benefit the economy. In the medium term, the external sector is also expected to gain momentum from increased production and quality of groundnuts and improved marketing arrangements. On the basis of these developments and the economic policies detailed above, the extemal current account deficit (excluding official transfers) is projected to narrow to about $11 \frac{3 / 4}{4}$ percent of GDP in 2001. As detailed in the letter of intent, the key assumptions include export volume growth of 8 percent, import volume growth of 5 percent, and an improvement in the terms of trade of 6 percent, reflecting lower oil prices and higher groundnut prices. Additional external resources to close the financing gap for 2001 include HIPC Initiative interim debt relief of US\$4.4 million ${ }^{10}$ and an additional EU grant of US\$1.6 million. Moreover, the revised program incorporates a slightly lower gross official reserve target of SDR 80.9 million in 2001 equivalent to a level of about 5.3 months of import cover.

25. The medium-term outlook balance of payments through 2006 is projected to improve on the basis of the proposed prudent policies and structural reforms (Table 3). In particular, the fiscal outlook assumes that the overall deficit (excluding grants) would decline to 3.1 percent of GDP in 2002 and to 2.7 percent in 2003 taking into account the nonrecurring payments to Alimenta and the commercial banks in 2001 and the impact (especially starting from 2002) of the measures to strengthen customs receipts and the reforms to improve expenditure control. In the outer years the overall fiscal deficit is projected to level off to about 2.2 percent of GDP. This outcome will permit government domestic debt to decline gradually to about 20 percent of GDP by 2006 . The improved fiscal outlook should help to contain the domestic interest payments and improve resource allocation to public investment from 4.9 percent of GDP projected in 2001 to about 7 percent by 2006. Gross investment is expected to increase from $17 \frac{1}{4}$ percent of GDP in 2000 to $20 \% / 4$ percent by 2004 , supporting a projected increase in GDP growth in excess of 6 percent in the outer years.

\footnotetext{
${ }^{9}$ In 1998 , the maximum tariff rate was 90 percent and there were up to 30 tariff bands. There are no other duties and charges on exports and imports.

${ }^{10}$ This amount was not incorporated in the program for 2000/01 as the Executive Boards of the World Bank and the Fund had yet to approve the enhanced HIPC Initiative assistance.
} 
Figure 3. The Gambia: Spread Between Parailel and Interbank Market Rates, January 2000-March 2001 (In percent); in terms of U.S. dollar per dalasi

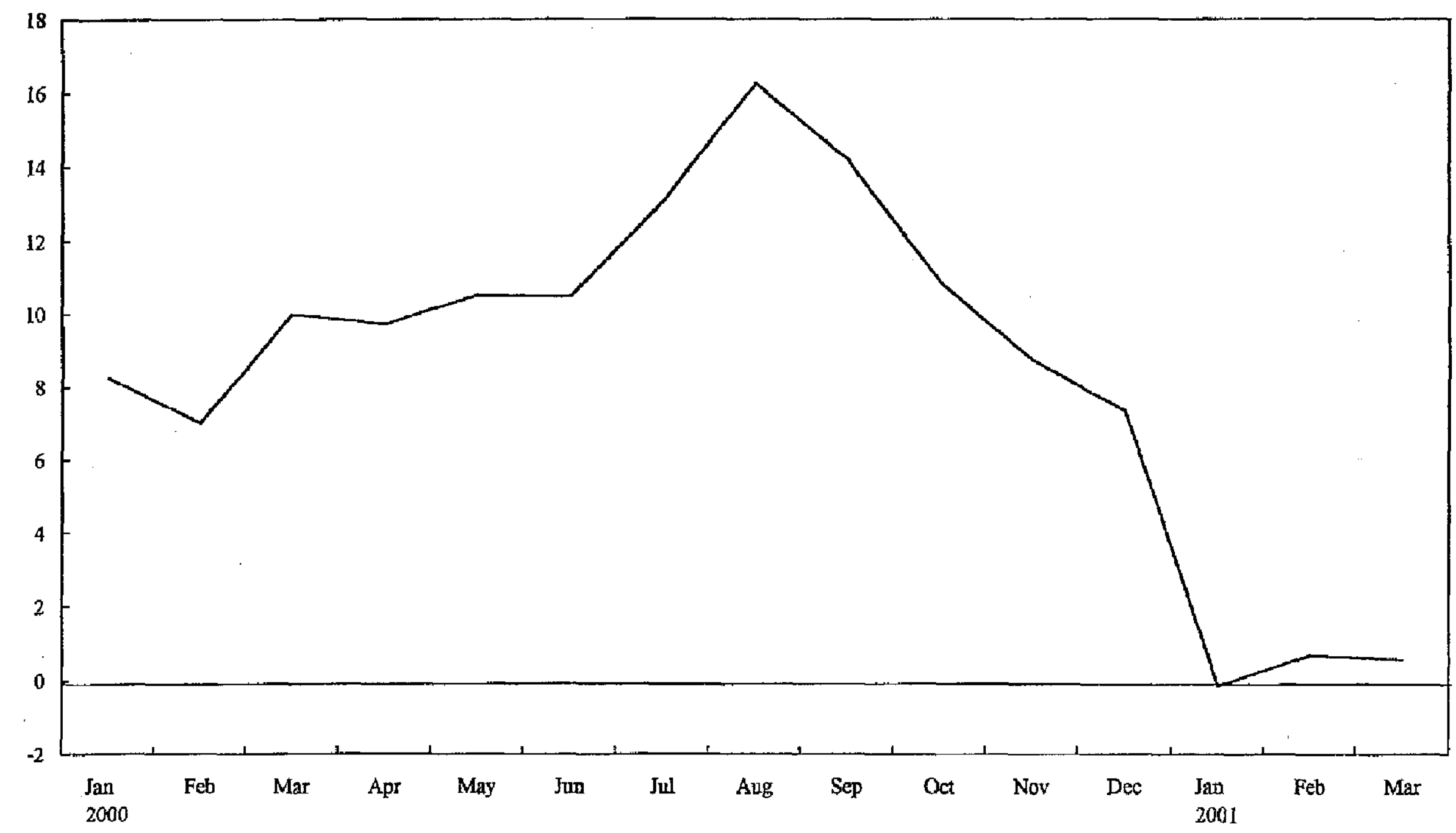

Sources: 'The Gambian authorities; and staff estimates. 


\section{Intraduction}

\section{Box 3. Financial Market Issues}

There are six commercial banks in The Gambia. With technical assistance provided by the MAE, the CBG and the banks are undertaking reforms to deepen the treasury bill market, introduce foreign currency deposits (FCDs) and strengthen financial sector supervision.

\section{Deepening treasury bill market}

Currently, the CBG issues 91-day and 182-day treasury bilis through biweekly auctions. The social security fund and the commercial banks account for most of the bids. The interest rate has not been flexible--it remained at 12 percent from March 2000 to January 2001, rose to 12.5 percent in February 2001 and has remained at that level ever since. The secondary market is not active.

Fund missions have made several recommendations aimed at deepening the treasury bill market and promoting more flexible interest rates, of which the following will be implemented in 2001. First, a book-entry system reduces administrative costs and ensures faster settlement, which would promote the secondary market. The CBG has trained staff with the book-entry software supplied and customized by the Fund, and will test it in a working environment during the June-August period before the final launch in September. Second, to increase the maturity range and explore the demand for such instruments, a new treasury bill of 364 days will be introduced at the auctions starting at end-August. Initially, the CBG expects that these new bills will account for 20-25 percent of the arzount to be floated. Third, noncompetitive bids of D 100,000 or less will be introduced.

The CBG plans to explore the licensing of treasury bill brokers and the introduction of repurchase operations, in part to promote the secondary market.

\section{Introducing FCDs}

The commercial banks in The Gambia are on track to introduce FCDs by end-2001, aiming to remove the competitive disadvantage vis-à-vis banks in the subregion. The FCDs will also facilitate the future operation of the proposed export processing zone.

Of the six banks, two will be ready to offer FCDs by September. The CBG prepared an action plan and will issue guidelines on FCD operations in August and work with the remaining four banks so that they could launch FCDs by end-2001. The CBG also emphasized the need for an anti-money laundering law and better corporate governance of the banks.

\section{Strengthening financial market regulation}

The revised drafts of the Financial Institutions Bill, which improves earlier legislation and better conforms with Basel Core Principles, and the Insurance Bill, which empowers the $C B G$ to regulate and supervise the insurance industry, have been submitted to the cabinet. The National Assembly is expected to enact both bills this year.

In supervising the commercial banks, the CBG applies primarily off-site analysis and, infrequently, on-site examination. The banks are generally sound. At end-March 2001, their risk-weighted capital adequacy ratios were greater than 12 percent, except for one bank, which had a ratio belaw 8 percent. Problem loans declined to 12.6 percent of total loans in 2000 (from 16.4 percent of loans in 1999). However, the $D$ 65 million in loans to groundnut marketing firms would have been classified as nonpefforming had the government not provided the guaranteed payments. Provisions against problem loans declimed from 90 percent in 1999 to 81 percent in 2000. Reflecting the structure of the economy, nearly half of the loans are concentrated in distributive trades. Close monitoring is being undertaken to safeguard the commercial banks from adverse shocks in this sector. 
Box 4. Microfinance in The Gambia

Introduction. The formal financial sector has been shrinking over the past decade, with the collapse of the country's largest barks - the Gambia Commencial and Development Bank and the Agricultural Development Bank in the late 1980s. Agricultural lending fell from about 35 percent of total bank lending in the 1980s to about 8 percent at end-1999, owing in part to the withdrawal of government guarantees and also to the collapse of the Gambia Cooperative Union. Furthermore, commercial banks have not expanded their activities in the nural areas: in 2001, they operated only three branches cutside the greater Banjul area. Accordingly, most financial services in the rural areas are providec by microfinance institutions (MFIs). Because their services target the low-income rural households, mainly women, they are at the cutting edge of poverty alleviation. In the context of the PRSP process and the enhanced HIPC Initiative debt-relief and poverty reduction policies, strengthening the financial intermediation provided by MFIs is key to supporting the income-generating activities undertaken by the poor.

A profile of MFIs in The Gambla. The delivery of miorofinance in The Gambia is carried out by a number of organizations, including the traditional, informal, but cohesive groups known as Osusus-which resemble rotating savings and credit associations, and Kafos (community groups) where ties of neighborhood, gender, age, kinship, and ethnicity create peer pressure that encourages participation. The close ties to the community and peer pressure have ensured high repayment rates within both the Osusus and Kafos. This has contrasted shaply with other MFIs, many of which failed because of low repayment rates. As a result, matry nongovernmental organizations (NGOs) decided to build on the traditional Osusus and Kafos as the main instinations for delivering microfinance. The mid-1980s witnessed a rapid growth in formal MFIs. An example is the village savings and credit associations (VISACAs)-started in 1988 with financial support from Germany. Village banks were created to mobjilize local savings to finance productive activities. Members contribute savings for several years before the money can be lent. Loans are quite small, with repayment rates of above 90 pencent. Similarly, interest rates are high, exceeding formal market rates for both savers and lenders. Some MFIs are facilitated by NGOs-such as Association of Farmers, Education and Traders and others by donors-such as Europear Development Fund. Generally, support has been limited to infrastructure development and training. Another example of a successfil MFI is the sebeme supported by Action Aid The Gambia (AATG), which started in the 1980s. Its lending is mainly in kind, including seasonal inputs (seed and fertilizer) and agricultural implements (plows, hoes, and weeders). The AATG does not charge interest to the Kafos, which, in turn, decide the rate of interest to charge their members. Groups with good repayment tecords are rewarded by a replenishment of their resources, which further encourages compliance.

Collateral In some MFIs, farma animals, farm tools, and jewelry are used efficiently and effectively to enforce contracts.

Recent policy initiatives to strengthen MFIs. The central bank, which is responsibie for the registration and supervision of VISACAs, initiated registration and monitoring of the MFIs in 1999. In May 2001, 14 had full licenses and 51 had provisional licenses, with agreenent on a timetable to meet requirements for a full license. The VISACA Promotion Center provides guidance on operational and technical issues relevant to MFIs. Furthermore, the Rural Finance and Community Initiative Project, which is being funded by the International Fund for Agricultural Development (IFAD) (US\$1 ! million) over six years, aims to strengthen the capacity of MFIs through funds channeled to the Gambia Women's Finance Association and on-lent to the MFIs.

Outreach. The target markets for the VISACAs are the poor. The average loan sizes range from US\$1 1 for the MFIs for rural chients to US $\$ 100$ for agrioulture and about US $\$ 300$ in the greater Banjul area for microentrepreneurs. The potential MFI portfolio at end-2000, including IFAD funds, is estimated at about D 240 million (US $\$ 15$ million) - 5 percent of GDP, 37 percent of private seetor credit, and 17 percent of commercial bank depasits. The CBG encourages the MFIs to place their deposits in treasury bills and other instruments with the commercial banks to strengthen linkages with the formal financial sector. As of 2000 , the number of MFI clients is estimated at about 40 percent of the total Gambian population. However, the figures understate the scope of the activities since many MFIs operate in the informal sector with no public records.

Challenges. Sustainable provision of microcredit remains a major challenge, as well as the strengthening of local institutional and managerial capacity to manage village based microcredit schemes. Creating linkages to the formal financial system to strengthen financial deepening while varying operational procedures among donors creates confusion for the recipients and could thwart efforts to create self-sustainable MFIs. 
26. The external current account deficit (excluding official transfers) is projected to improve to $11 \frac{1 / 4}{4}$ percent of GDP in 2002 and to about $101 / 2$ percent in 2003 and thereafter gradually decline to about 10 percent by 2006 . The volume of groundnuts exports will grow by an average of 4 percent during 2002-03 and thereafter by an average of about 5 percent per year. Further modest improvements are also expected in the exports of cotton, fresh fruits, and vegetables. The export of fish and fish products, in particular, will benefit from the recent completion of artisanal and cold storage facilities. Tourism receipts are expected to rise by 10 percent in 2002 and more modestly in 2003 and by an annual average of 6 percent during 2004-2006, as operators improve services and the government steps up promotional activities. Import volumes are projected to rise by about 6 percent during 2002-03, as the reexport trade continues to recover following the removal of the preshipment inspection scheme and the reduction and rationalization of the external tariffs in 2000 . The reexport volumes are expected to increase by about $51 / 2$ percent per year during 2004-06. The financing gaps projected for the period 2002-2006 are expected to be covered by a combination of donor grants and debt relief under the HIPC Initiative-permitting gross official reserves to increase to about 5.6 months of imports.

\section{The authorities indicated that they remained committed to a liberal trade and} exchange system. They will continue to assess the impact of external tariff reforms, as well as reforms in neighboring West African Economic and Monetary Union (WAEMU) countries (which have a maximum external tariff of 20 percent). Efforts have been intensified to improve balance of payments data based on the recommendation of a Fund technical assistance mission in September 2000. The authorities also intend to introduce ASYCUDA II, inter alia, to better integrate customs revenue and balance of payments data. The reduction in external tariff, together with the pursuit of a market-based flexible exchange rate-which resulted in a further depreciation of the dalasi by an estimated 5 pereent in real effective terms curing the first quarter of 2001 - have benefited external competitiveness. The mission concurred with the authorities' assessment and considered the prevailing exchange, in conjunction with the pursuit of prudent fiscal and monetary policies, as broadly appropriate to maintain The Gambia's external competitiveness.

28. The Gambia is on track to achieve external debt sustainability within the context of the enhanced HIPC Initiative. It is now receiving interim debt relief and expects to reach the completion point, subject to the triggers outlined in EBS/00/242 (11/28/00), by end-2002. Medium-term projections indicate that total outstanding external debt will fall from 108.9 percent of GDP this year to about 90 percent of GDP in 2006. External debt service (including the Fund) is similarly projected to decline from 15.6 percent to 9.2 percent of GDP during the same period. Measures have been taken to provide the external debt unit at DOSFEA with better staffing and equipment in order to improve the quality and timeliness of external debt data. The authorities have also contacted all creditors to follow up with debt relief under the enhanced HIPC Initiative. In this context, they expect that by August 2001 agreement will be reached on the debt owed to the Norwegian export guarantee agency arising from a government-guaranteed loan to the Senegambia Beach Hotel. 
29. The Gambia will need to continue to manage its external debt prudently and rely exclusively on external grants or long-term loans on highly concessional terms. Payments to the Fund in 2001 will total SDR 0.3 million (plus SDR 0.25 million to the Saudi Fund for Development), equivalent to 0.2 percent of the projected exports of goods and nonfactor services. The Gambia has an excellent record in meeting its debt-service obligations to the Fund, and, given the projected improvements in its financial policies, it is expected to discharge its future obligations to the Fund in a timely manner.

\section{ThE PRSP PROCESS}

30. The PRSP process is on schedule for the preparation of a full PRSP by end-2001. Notwithstanding the delayed roundtable meeting, donors have continued to support the PRSP process including the key steps outlined in para. 25 of the letter of intent. An outline of the PRSP was cireulated in May for comments and drafting should commence by late summer. Meanwhile, the authorities have made good progress with education and health reforms, which - in addition to tracking poverty-reducing expenditure and the privatization of Alimenta assets - - together with the implementation of the PRSP, are triggers for the enhanced HIPC Initiative floating completion point in December 2002.

\section{Social impact of the program ${ }^{11}$}

31. In addition to the pro-growth and anti-inflationary stance of macroeconomic policies, the I-PRSP incorporates sector policies that are, inter alia, part of the program pillars to reduce poverty. The approach is based on promoting income-earning activities in the key sectors, namely, agriculture, tourism, and trade, better targeting and delivering of education and health services, and focusing on employment creation, especially for the youth.

32. The low-inflation objective serves to protect the limited purchasing power of the poor, who predominate in rural agricultural activities and the urban informal sector. The PRGF-supported program has incorporated a significant adjustment in petroleum product prices, whose short-term adverse impact on consumers would be reversed when world oil prices decline. The impact on the poor has been somewhat mitigated through the provision of cross subsidies to kerosene, which is predominantly used by low-income households; however, improved government revenue resulting from higher fuel prices has helped to sustain expenditure, including those targeted to the poor. The PRGF-supported program has also supported flexible exchange rates, which, with the depreciation of the dalasi, have resulted in higher prices for imports. The poor consume mainly nontraded goods but would

\footnotetext{
1 This social impact analysis is a first step toward qualitatively analyzing the potential poverty impact of some of the key policies contained in the PRGF arrangement. The next stcp is to work closely with the government, as part of the full PRSP, in developing some quantification of the impact of individual policies using data from both the household surveys and the participatory poverty assessments (PPAs).
} 
still be adversely affected by some higher import prices. However, the poor who are involved especially in the groundnut, tourism, and reexport sectors, tend to benefit when the dalasi depreciates, resulting in larger export proceeds and increased employment.

33. The fiscal strategy to contain the overall deficit and, eventually, the domestic debt has in the short term limited government expenditure and put emphasis on revenue collection that have reduced the disposable income and, therefore, the consumption of the public, including the poor. This effect has been mitigated by progressive income taxes and the exemption or low taxation of items consumed by the poor, such as rice and medicine, while expenditure targeting of the poor, especially on services, has helped to increase the share of some spending benefiting the poor. Reforms to improve the budget process focusing on the transparency and accountability of public expenditure should reduce fraud and increase efficiency in the allocation and targeting of increased resources to the poor. As indicated above, the tight monetary policy is putting a greater adjustment burden on the government in order to permit an adequate increase in private sector credit. However, the share of credit going to the poor is limited by antiquated business legislation and lack of collateral. Financial sector policies and reforms, complemented by fiscal reforms, should reduce financial intermediation costs and interest rates, which in turn, should benefit the public, including the poor. However, these policies are likely to become effective only gradually. In the meantime, the authorities have targeted reforms in microfinance as a faster way of targeting the poor and helping them improve their income-generating activities and ability to withstand economic shocks. ${ }^{12}$

34. The key sectoral measures targeting the earning capacity include payments to Alimenta, which should serve as a catalyst for the privatization of its former assets and the related reforms in groundnut marketing. The expected outcome is a considerable improvement in the production and marketing of groundnuts, which should benefit the poor households and help to reverse the major increase in the incidence of poverty experienced in The Gambia between 1992 and 1998 (see EBD/00/99; 11/28/00). The reduction and rationalization of the extemal fariff, together with the establishment of an export processing zone to be supported by the proposed Trade Gateway project, are expected to improve the external competitiveness of The Gambia, boost foreign investment, and significantly increase the scope of the key entrepot activities. Together, these measures should provide the poor with better employment opportunities, marketing of their produce, and access to imported inputs. A positive outcome for youth employment would curtail problems such as HW/AIDS, the potential for participation in drug and arms smuggling and mercenary adventure, and significantly contribute to poverty reduction.

35. Adhering to the work agenda to improve the social impact analysis is a priority. Among other areas, the authorities should focus on (a) bottlenecks that impede the

${ }^{12}$ This is consistent with the views of the poor, as evidenced by the participatory poverty assessment survey. For details, see Box 1 in EBS/00/241 (11/28/00). 
effectiveness of current policies, including land and legal reforms to facilitate access to assets by the poor and especially women; (b) the inadequate social and poverty statistics informing policies; and (c) the lack of well defined output targets against which to measure progress. Discussions are ongoing to access technical assistance, notably from the DFID to launch formal social impact analysis studies, better integrate the household surveys with the PPA and SPP exercises, and, separately, to undertake a housing and population census in 2003. Fund-assisted programs will focus on fiscal reforms and improvements in macroeconomic data.

\section{Technical Assistance and Statistical Issues}

36. As detailed in the attached letter of intent, The Gambia has made some headway in strengthening its statistical base. While such statistics arc broadly adequate for surveillance purposes, further improvements are needed in data quality and coverage, especially with regard to the major components of the balance of payments, the national accounts and prices, public investment, the public enterprise sector, employment, and social and poverty data. The Fund and donors have provided technical assistance to improve data compilation in a number of areas, and The Gambia is a participant in the Fund's General Data Dissemination System (GDDS) and uses the framework to improve the quality of data. Moreover, the government intends to utilize the donor roundtable (likely to take place by mid-2002, to mobilize external support for the PRSP) to work closely with donors in developing a comprehensive and bettercoordinated technical assistance program to support the PRSP reforms and the closely related elements of the UN Integrated Preventive Strategy.

\section{Prior Actions and Program Monitoring}

37. To enhance the success of the program, the following prior actions were implemented by the government: (a) the introduction of a comprehensive accounting framework to monitor poverty-reducing expenditure, including expenditure funded from debt relief under the enhanced HIPC Initiative; and (b) the submission to parliament of the 2001 budget funded from the interim debt relief under the HIPC Initiative.

38. The program will be monitored through the quantitative benchmarks and quantitative performance criteria specified in Tables 1 and 2 the letter of intent. The six quantitative performance criteria set for end-September 2001, will also serve as benchmarks for end-June 2001. Five structural benchmarks are still outstanding, set for specific dates during the period through end-September 2001 ; the rationale for structural conditionality is provided in Box 5 . A continuous performance criterion on the avoidance of external payments arrears has also been set. Program implementation will be evaluated during a second review, to be completed by December 11, 2001.

\section{STAFF APPRAISAL}

39. The Gambia's economic performance during 2000 and the first half of 2001 has been mixed. The economy has continued to grow briskly while maintaining low inflation with the 
benefit of good weather. However, there were slippages in fiscal policy through March 2001, partly related to efforts to address the Alimenta property dispute and its impact on groundnut financing. Moreover, the authorities are continuing to implement broad-based structural reforms despite a number of delays. In response to the slippages, the authorities have implemented corrective financial measures and, with the benefit of tcchnical assistance, including from the Fund, are in a position to regain momentum in implementing the structural reform agenda. The Gambia is starting from a relatively low level and thus faces a considerable challenge in its attempts to meet the IIIPC Initiative and PRSP public expenditure tracking standards, but the authorities have established an adequately ambitious comprehensive public finance reform program. Moreover, the authorities rightly plan to coordinate donor techmical assistance support in these areas as part of a comprehensive program that would be presented at a roundtable meeting to support implementation of the PRSP reforms and elements of the complementary UN Integrated Preventive Strategy.

40. The revised program for the balance of 2001 appropriately aims at strengthening areas where slippages have occurred, including use of prior actions. It also focuses on strengthening structural reforms to improve the environment for robust private sector activity and enhance the delivery and monitoring of public services. The reinforcement of the program is essential to restore macroeconomic stability and contribute to a durable reduction in poverty in The Gambia.

41. To these ends, the authorities need to strengthen governance, including completion of the settlement with Alimenta and a timely implementation of the comprehensive governance program adopted by the government and incorporated in the PRSP. A number of elements of the governance program are critical to broadening the participatory process in the PRSP and the authorities have made commendable headway in implementing them. However, challenges remain on several fronts - also of concern to donors - notably, the pending local and national elections, for which the program has provided the necessary funding in the budget for 2001 . The staff welcomes the progress made in some of these areas and urges the authorities to continue to actively seek broad consultations in implementing the rest. It urges the authorities to adhere to the target date for completing the full PRSP.

42. Fiscal performanee should be strengthened in line with the revised program and the goal of maintaining a sustainable level of government domestic debt. On the revenue side, the improvement in customs administration remains critical for, inter alia, the sustainability of the recent external tariff reforms. Budgetary reforms to enhance the transparency and accountability of public expenditure are also crucial to the PRSP and HIPC Initiative process. The staff encourages the authorities to persevere with these reforms and a return to the timely audit of public accounts. The authorities should also collaborate effectively with donors in extending the nascent PER exercise to include the establishment of a medium-term expenditure framework encompassing all major expenditure programs. 
Box 5. Structural Conditionality in the Third Annual PRGF Arrangement for The Gambia

\author{
Coverage of structural conditionality in the current program
}

As detailed in Table 2 of Appendix I, structural conditionality in the third annual PRGF arrangement for The Gambia covers four areas. First, the inclusion of the tracking of poverty reduction expenditure in conditionality reflects the critical role of public resource management in the context of the strategy to reduce povexty; hence the use of a structural petformance criterion and the subsequent two prior actions. Second, issues in data compilation (balance of payments, external and domestic debt, and national accounts) were included in order to encourage the authorities to improve their capacity to use the GDDS, formulate timely policies, monitor the program, and expedite the provision of data to the Fund for program monitoring and publication. Third, customs and tax administration is covered in conditionality in order to enhance revenue mobilization while promoting measures that will ensure the sustainability of the recent sizable reduction and rationalization of extenal tariffs. Fourth, the financial sector reforms covered in conditionality include the introduction of a book-entry system for treasury bills and foreign currency deposits. These are expected to promote the development of the money and foreign exchange markets, and enhance efficiency and interest rate tlexibility.

\title{
Status of structural conditionality from earlier programs
}

The third annual PRGF arrangement does not include structural conditionality on (a) the restructuring and privatization of public enterprises; (b) the procurement code; (c) the investment code; and (d) the public investment program (PIP), all of which were covered by structural benchmarks in the earlier PRGF annual arrangements. The World Bank has the lead role in all these areas, and, except for item (a), all these have been addressed with legislation, interim codes, and an initial review of the PIP. The conditionality on privatization was not fully met, but the emphasis shifted to providing legal frameworks for privatization and regulation, both of which were approved by parliament in the 2000/01 session. Meanwhile, to deal with financial problems of public enterprises, the current PRGF program incorporated quarterly budget targets to eliminate governmentpublic enterprise cross arrears. Moreover, the third annual PRGF arrangement was refocused to include structural conditionality that was more in the areas of Fund expertise and had a more direct bearing on macroeconomic issues.

\section{Structural areas covered by World Bank lending and conditionality}

Existing and prospective (in fiscal year (FY) 2002) World Bank lending is all in projects, of which those in education and health have conditionality that is reflected also in the HIPC floating completion triggers. The World Bank has not scheduled any credit or structural adjustment lending in FY 2002 bit is considering such new lending in FY 2003; a budget support operation under consideration could assist a further reduction in external tariffs and arrangements to restructure/buy back domestic debt.

\section{Other relevant structural conditions not included in the current program}

These conditions comprise four main areas. First, reforms ane linked to the settlement of the Alimenta property dispute, notably timely payments to Alimenta and the privatization of its assets and the complementary groundnut marketing and production reforms. These areas are covered by agreements and arrangements with the European Union--the lead donor in the sector. Moreover, the privatization of the two Alimenta groundnut processing plants is included in the HIPC Initiative floating completion triggers. Second, governance issues have been explicitly raised by donors, notably the timing of local elections. These are issues that go beyond the mandate of the Fund and are monitored by the relevant donors. Third, the PRSP process, including participatory programs, sector policies, public expenditure reviews, the medium-tcrm expenditure framework, and social impact analysis, is supported by various donors and $\mathrm{NGO}$; however; it has not been covered by specific conditionality in the PRGF-supported program. Finally, liquidity forecasting by the central bank has been developed as far as it can be by the monetary authority acting on its own. Additional conditionality in this area is now dependent on ongoing reforms in the accounts of the central government, which would provide timely inputs into the formulation of monetary policy and catalyze additional reforms. 
43. The authorities need to continue to pursue prudent monetary policy to maintain low inflation while providing adequate private sector credit growth. Supporting reforms should emphasize the expanded use of indirect instruments, taking advantage of Fund technical assistance. The central bank plans more timely and regular sales of foreign exchange in the market, for smoothing purposes. In addition, it is taking measures to improve the operation of the interbank foreign exchange market that have reduced the spread between the parallel and interbank foreign exchange rates. Moreover, these measures will need to be underpinned by prudent financial policies and supported by the planned introduction of foreign currency deposits. The staff welcomes the measures to improve the soundness of the financial system and urges the authorities to press on with the recovery of the outstanding loans from the 1999/2000 groundnut season.

44. The consolidation and broadening of other structural reforms remain key to improving private sector activity and accelerating a reduction in poverty. Key reforms include measures to improve business legislation, such as the regulation and privatization of public enterprises. Also, reforms that will provide for a sustainable marketing arrangement for groundnuts without direct government involvement should be put in place. The staff urges that timely and coordinated reforms be implemented in these areas, as well as those that will contribute to the attainment of the I-PRSP objectives.

45. The staff welcomes the further reduction in the external tariff, which has put The Gambia abead of other countries in the region. The staff considers the current level of the exchange rate to be appropriate, in the context of the proposed pursuit of prudent financial policies, for maintaining the country's external competitiveness.

46. Notwithstanding the progress that has been made in improving economic and financial data and The Gambia's commitment to participate in the GDDS, the staff urges the authorities to continue their efforts to improve the timeliness and quality of data, especially in the national accounts and prices, fiscal, and balance of payments. Moreover, the social and poverty database remains in great need of improvement in light of the objectives outlined in the PRSP. While the provision of data to the Fund does not prevent effective surveillance or program monitoring, the delays in reporting and the quality of data should be significantly improved to facilitate the analysis of economic developments.

47. Possible risks to the implementation of the program include delays in dealing with governance issues and implementing structural reforms, especially in the fiscal area, which are critical not only to the program but to the PRSP and HIPC Initiative process as well. Moreover, the heavy burden of implementing a broad range of measures will be a major tcst of the limited economic management capacity in the country. Thus, the staff welcomes the authorities' intention to intensify collaboration with donors and the Fund to ensure timely access to technical assistance.

48. The quantitative performance criteria were missed on account of nonrecurring payments to Alimenta and the commercial banks but also because of weaknesses in customs revenue collections for which corrective measures have been implemented. Moreover, the 
program for the balance of 2001 envisages additional measures and reforms, notably those to address underlying weaknesses in the fiscal and groundnut marketing, as described in the attached letter of intent. On this basis, the staff recommends to the Executive Board (a) approval of the authorities' request for waivers on the nonobservance of four performance criteria and the structural performance criterion; and (b) completion of the first review under the thitd annual PRGF arrangement.

49. It is recommended that the next Article IV consultation with The Gambia be held on the standard 12-month cycle. 
Table 1. The Gambia: Second and Third Annual Arrangements Under the Existing PRGF Arrangement, 1999-2001

\begin{tabular}{|c|c|c|c|}
\hline \multirow[t]{2}{*}{ Date } & \multirow{2}{*}{ Event } & \multicolumn{2}{|c|}{ Disbursement } \\
\hline & & $\begin{array}{c}\text { (In millions } \\
\text { of SDRs) }\end{array}$ & $\begin{array}{c}\text { (In percent } \\
\text { of quota) }\end{array}$ \\
\hline October 1, 1999 & Program period begins & & \\
\hline November 19,1999 & Second annual arrangement approved & 3.435 & [1.] \\
\hline March 31, 2000 & Test date & & \\
\hline July 19,2000 & First review completed & 3.435 & I1.1 \\
\hline September 30,2000 & Test date & & \\
\hline December 11,2000 & Second review (yeat-end) not completed & 0.000 & 0.0 \\
\hline December I l, 2000 & Third annual arrangement approved l/ & 3.435 & 11.1 \\
\hline March 31,2001 & Test date & & \\
\hline July 1,2001 & First midyear teview completed & & \\
\hline July 15,2001 & Purchase & 3.435 & 11.1 \\
\hline September 30,2001 & Test date & & \\
\hline December 11,2001 & Second review completed & & \\
\hline December 15, 2001 & Purchase & 3.435 & 11.1 \\
\hline December 31,2001 & Arrangement expires & & \\
\hline
\end{tabular}

1/ In conjunction with the request for the thirc annual anargement, the authorities have also requested an extension of the three-year commitment period through end-December 2001 to allow for the last disbursement. 
Table 2. The Gambia: Fund Position During the Period of the PRGF Arrangement, 2000-01

\begin{tabular}{|c|c|c|c|c|c|}
\hline & \multirow{2}{*}{$\begin{array}{c}\text { Outstanding } \\
\text { December } 31 \text {, } \\
2000\end{array}$} & \multicolumn{4}{|c|}{2001} \\
\hline & & $\begin{array}{l}\text { Jan.- } \\
\text { Mar. }\end{array}$ & $\begin{array}{l}\text { Apr.- } \\
\text { Jun. }\end{array}$ & $\begin{array}{l}\text { Jul.- } \\
\text { Sep. }\end{array}$ & $\begin{array}{l}\text { Oet.- } \\
\text { Dec. }\end{array}$ \\
\hline & \multicolumn{5}{|c|}{ (In millions of SDRs) } \\
\hline Net use of Fund credit & & -0.1 & 3.4 & 3.3 & 0.0 \\
\hline Transactions under tranche policies & & 0.0 & 0.0 & 0.0 & 0.0 \\
\hline Purchases & & 0.0 & 0.0 & 0.0 & 0.0 \\
\hline Ordinary resources & & 0.0 & 0.0 & 0.0 & 0.0 \\
\hline Borrowed resources & & 0.0 & 0.0 & 0.0 & 0.0 \\
\hline Repurchases & & 0.0 & 0.0 & 0.0 & 0.0 \\
\hline Ordinary resources & & 0.0 & 0.0 & 0.0 & 0.0 \\
\hline Borrowed resources & & 0.0 & 0.0 & 00 & 0.0 \\
\hline Transactions under special facilities & & 0.0 & 0.0 & 0.0 & 0.0 \\
\hline Loans under: & & -0.1 & 3.4 & 3.3 & 0,0 \\
\hline Structural Adjustment Facility & & 0.0 & 0.0 & 0.0 & 0.0 \\
\hline Drawings & & 0.0 & 0.0 & 0.0 & 0.0 \\
\hline Repayments & & 0.0 & 0.0 & 0.0 & 0.0 \\
\hline Enhanced Structural Adjustment Facility & & -0.1 & 3.4 & 3.3 & 0.0 \\
\hline Drawings & & 0.0 & 3.4 & 3.4 & 0.0 \\
\hline Repayments & & -0.1 & 0.0 & 0.0 & 0.0 \\
\hline HIPC Initiative debt relief & & 00 & $\ldots$ & $\ldots$ & $\ldots$ \\
\hline Total Fund credit outstandirg & 13.9 & 13.8 & 17.3 & 20.6 & 20.6 \\
\hline Under tranche policies & 0.0 & 0.0 & 0.0 & 0.0 & 0.0 \\
\hline Under special facilities & 0.0 & 0.0 & 0.0 & 0.0 & 0.0 \\
\hline Under Structural Adjustment Facility & 0.0 & 0.0 & 0.0 & 0.0 & 0.0 \\
\hline \multirow[t]{2}{*}{ Under Enhanced Structural Adjustment Facility } & 13.9 & 13.8 & 17.3 & 20.6 & 20.6 \\
\hline & \multicolumn{5}{|c|}{ (In percent of quota) } \\
\hline Total Fund credit outstanding & 44,8 & 44.5 & 55.5 & 66.3 & 66.3 \\
\hline Under tranche policies & 0.0 & 0.0 & 0.0 & 0.0 & 0.0 \\
\hline Under special facilities & 0.0 & 0.0 & 0.0 & 0.0 & 0.0 \\
\hline Under Structural Adjustment Facility & 0.0 & 0.0 & 0.0 & 0.0 & 0.0 \\
\hline Under Enhanced Structural Adjustment Facility & 44.8 & 44.5 & 55.5 & 66.3 & 66.3 \\
\hline
\end{tabular}

Source: IMF, Treasurer's Department. 


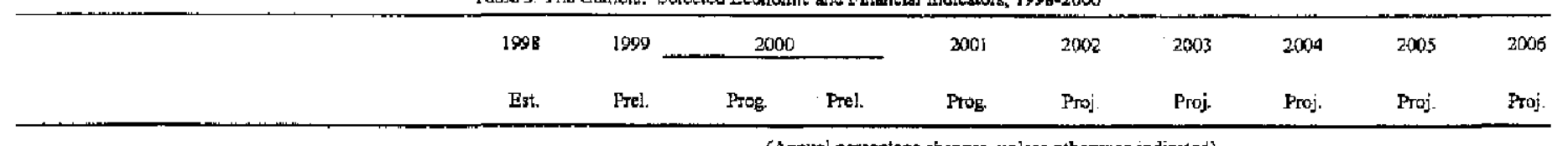

National income and prices

GLP at constatt prices

\section{GDP deflator}

Consumex price index (period average)

Consumer price irdex (end of period)

(Antual percentage changes, unjess otherwise indicaled)

\section{Extermal sector}

Exports, to.b. (in SDRs)

Imports, fob. (in SDRs)

Export volune (excluting reexports)

Import volume (excluding imports for reexport)

Tems of trade $\mathrm{l} /$

Wominal effective exchange rate (period average

Retal effective exchange rete (period average)

$\begin{array}{lll}3.5 & 6.4 & 5 . \\ 2.5 & 4.4 & 3 . \\ 1.1 & 3.8 & 3.4 \\ 4.8 & 1.7 & 2.7\end{array}$

$\begin{array}{ll}5.3 & 5.6 \\ 3.4 & 3.8 \\ 3.4 & 0.9 \\ 2.7 & 0.2\end{array}$

5.6
3.8
0.9
0.2

$5.7 \quad 5.8$

$4.0 \quad 3.0$

5.8
3.0
2.5

$4.0 \quad 2.5$

3.5

2.5

2.5

6.2

3.0

2.5

2.5

6.2

3.0

$\begin{array}{rr}9.0 & 13.8 \\ 3.1 & 7.7 \\ 29.5 & 1.5 \\ -4.1 & 0.2 \\ -2.0 & 6.2 \\ -2.6 & \ldots \\ -4.3 & \ldots\end{array}$

$\begin{array}{rr}8.5 & 3.5 \\ 6.0 & 3.1 \\ 4.1 & 4.9 \\ 4.3 & 4.5 \\ 10.9 & 6.7 \\ \ldots & \ldots \\ \ldots & \ldots\end{array}$

10.2

$55.5 \quad-10.7$

$18.7-11.9$

$-0.1 \quad-19.8$

$-1.2 \quad-5.0$

$-16 \quad-23$

Government budget

Domestic revente

Tolal expenditure and net lending

Curent expenditure

Development. expenditure and net lenwing

\section{2}

12.8

13.3

14.1

11.2

110

8.7

6.6
11.1

$$
20.2
$$

7.4

8.3

$11.1 \quad 20.7$

2.7

5.4

Money and credit

Net domentic assets a/

Credit to the government $2 /$

Credit to the private sector $2 / 3$ /

Broad mantey

Velocity (GDP relative to broad money)

Treakury bill rate (in percent; end of period)

$\begin{array}{rrr}-1.9 & 8.7 & 11.2 \\ -1.7 & 5.4 & -2.7 \\ 5.6 & 8.2 & 4.7 \\ 10.2 & 12.1 & 17.3 \\ 3.4 & 3.3 & 3.1 \\ 14.0 & 12.5 & \ldots\end{array}$

$\begin{array}{rrrr}27.9 & -0.9 & 7.5 & 6.9 \\ 3.1 & 4.0 & -1.4 & -3.4 \\ 4.4 & 8.0 & 8.9 & 10.3 \\ 34.1 & 7.9 & 8.7 & 9.0 \\ 2.7 & 2.8 & 2.8 & 2.8 \\ 12.0 & \ldots & \ldots & \ldots\end{array}$

Gross domestic inwestment and suvings

\section{Gross invetiment}

Government

Private 2:

Gross domestic savings

Gross national sevings

Central govermment buaget.

Batance excluding garps 4 '

Batance inciuding ganis $4 /$

Basic primary balance

Current balance

Revenuse

Net foreign financing

Net domestic financing

Stack of domestic debt

19

17.3
4.6
12.7
4.9
12.7

(in percen of GDP)

$\begin{array}{llll}17.9 & 19.3 & 199 & 20.3\end{array}$

21.5

$4.9 \quad 5.6$

$13.6 \quad 13.7$

$5.6 \quad 7.5$

$15.3 \quad 15.1$

6.0

$\begin{array}{rr}-4.4 & 4.8 \\ -2.4 & -3.5 \\ 5.6 & 4.6 \\ 0.7 & -0.2 \\ 18.8 & 17.8 \\ 3.2 & 0.6 \\ 9.8 & 3.6 \\ 25.9 & 27.0\end{array}$

$\begin{array}{rr}-3.5 & .3 .6 \\ -1.5 & -1.4 \\ 6.6 & 4.6 \\ 2.0 & 1.2 \\ 20.0 & 18.5 \\ 0.8 & -0.8 \\ 0.3 & 2.6 \\ 26.6 & 31.4\end{array}$

$\begin{array}{rr}-3.9 & -3.1 \\ -1.0 & -0.9 \\ 3.7 & 4.6 \\ -0.9 & 0.6 \\ 19.2 & 19.5 \\ -1.5 & 0.8 \\ 2.5 & 0.1 \\ 27.7 & 22.7\end{array}$

\section{$-2.7$}

0.5

5.1

16

19.9

1.5

$-1.0$

20.3
6.2

14.1

$\$ .8$

17.1

$$
6.5
$$

15.0

10.0

18.6

$-2.3 \quad-2.2$

$\begin{array}{rr}-2.3 & -2.2 \\ 0.0 & 0.2\end{array}$

5.5

2.3

20.4

0.9

$-0.8$

20.0

External secter

Curtent aecorint balance

Excluding official transfers

Including official transfers

Exterral debt oustanding. including Fund

$\begin{array}{rrrrrrrrrr}11.6 & -11.5 & -12.3 & -12.0 & -11.8 & -11.2 & -10.4 & -10.3 & -10.1 & -9.9 \\ -3.0 & -4.3 & -4.0 & -4.6 & -2.6 & -4.2 & -3.6 & -3.2 & -2.9 & -2.7 \\ 103.3 & 98.4 & 102.3 & 100.1 & 108.9 & 106.9 & 96.3 & 96.1 & 92.8 & 89.7\end{array}$

Extemal debt service $5 f$

Jisludirg Fund

Excluding Find

$11.4 \quad 11.4$

9.4

(In percent of exports and trave] inoome)

$\begin{array}{ccccccc}\text { B.5 } & 15.6 & 11.2 & 10.1 & 9.6 & 9.2 & 9.2\end{array}$

Cursest account balance

Excluding official transfers

Including official transfers

DVarall balance of payments

Gross official reserves (end of period)

In monthe of imports, c.if.

Duter the taxt 12 months

Plus all other services payments

Solrew: The Gambiar euthorities, and Fund ataff estimates and projections.

I/ Excluding reexports and impors for reexport.

$2 f$ In pereent of broad noney at the beginuing of the perion

3/ Includes public enteprises.

4/On a commitment besis, exeluding HIPC Initiative supported expenditure.

$5 /$ in 2001, the increase in dabt service mainly reflects payments to Aticnerta (the last payment will be in July 2001) 
Tabje 4. The Garnbia: Selected National Accounts Indicators, 1998-2003

\begin{tabular}{|c|c|c|c|c|c|c|c|}
\hline & \multirow[t]{2}{*}{1998} & \multirow{2}{*}{$\begin{array}{r}1999 \\
\text { Est. }\end{array}$} & \multicolumn{2}{|c|}{2000} & \multirow{2}{*}{$\begin{array}{l}2001 \\
\text { Prog. }\end{array}$} & \multirow{2}{*}{$\begin{array}{l}2002 \\
\text { Proj }\end{array}$} & \multirow{2}{*}{$\begin{array}{c}2003 \\
\text { Proj. }\end{array}$} \\
\hline & & & Prog. & Prel. & & & \\
\hline & \multicolumn{7}{|c|}{ (Percentage changes) } \\
\hline \multicolumn{8}{|c|}{ Gross domestic product at current market prices } \\
\hline Agriculture & 0.0 & 29.4 & 6.2 & 11.4 & 6.2 & 5.0 & 5.0 \\
\hline Groundnuts & -5.9 & 67.3 & 5.0 & 12.3 & 7.0 & 5.0 & 5.0 \\
\hline Other crops & 2.9 & 31.1 & 8.0 & 16.4 & 7.0 & 5.0 & 5.0 \\
\hline Livestock & 4.0 & 4.0 & 4.0 & 3.0 & 4.0 & 5.0 & 5.0 \\
\hline Forestry & 3.9 & 4.1 & 4.0 & 3.9 & 4.0 & 5.0 & 5.0 \\
\hline Fishing & -13.2 & 6.0 & 7.9 & 2.9 & 4.0 & 5.0 & 5.0 \\
\hline Industry & 5.3 & 2.4 & 2.9 & 5.1 & 7.3 & 6.4 & 6.4 \\
\hline Manufactuting & 2.5 & 1.5 & 2.0 & 2.0 & 3.0 & 5.0 & 5.0 \\
\hline Large and medilan masufacturing & 2.5 & 1.5 & 2.0 & 2.0 & 3.0 & 5.0 & 5.0 \\
\hline Small manufacturing & 2.5 & 1.5 & 2.0 & 2.0 & 3.0 & 5.0 & 5.0 \\
\hline Construction and mining & 7.8 & 3.3 & 5.0 & 10.0 & 12.0 & 8.0 & 8.0 \\
\hline Electricity and water supply & 10.0 & 2.9 & -3.0 & -3.0 & 6.0 & 5.0 & 5.0 \\
\hline Services & 4.6 & 1.9 & 3.3 & 3.1 & 4.7 & 5.8 & 5.8 \\
\hline Trade & 7.1 & -4.4 & 3.9 & 5.3 & 6.3 & 7.2 & 7.1 \\
\hline Groundnuts & -5.9 & 3.6 & 10.0 & 0.8 & 8.0 & 8.0 & 8.0 \\
\hline Others & 9.2 & -5.5 & 3.0 & 6.0 & 6.0 & 7.0 & 7.0 \\
\hline Hotels and restaurants & 7.5 & 3.4 & -4.0 & -12.8 & 5.0 & 7.0 & 7.0 \\
\hline Transport and communications & 4.4 & 4.9 & 4.7 & 5.2 & 5.2 & 6.0 & 6.0 \\
\hline Transport & 6.5 & 0.0 & 3.0 & 4.0 & 4.0 & 6.0 & 6.0 \\
\hline Communications & 2.7 & 8.8 & 6.0 & 6.1 & 6.0 & 6.0 & 6.0 \\
\hline Real estate and business services & 1.0 & 0.5 & 4.0 & 2.2 & 3.0 & 6.0 & 6.0 \\
\hline Public administration & 4.0 & 2.8 & 2.7 & 4.6 & 3.0 & 3.0 & 3.0 \\
\hline Other services & 1.5 & 1.0 & 3.0 & 1.7 & 3.0 & 7.0 & 7.0 \\
\hline GDP at factor costs & 3.7 & 7.7 & 4.0 & 5.4 & 5.4 & 5.7 & 5.7 \\
\hline Indirecl tax (tiet) & 2.5 & $-2: 7$ & 14.7 & 6.7 & 8.1 & 6.7 & 6.6 \\
\hline GDP at market prices & 3.5 & 6.4 & 5.3 & 5.6 & 5.7 & 5.8 & 5.8 \\
\hline GDP deflator & 2.5 & 4.4 & 3.4 & 3.8 & 4.0 & 3.0 & 3.0 \\
\hline
\end{tabular}

Soruces: The Gambian authorities; and staff projections. 
Table 5. The Gambia: Central Government Financial Operations, 1998 + 2003

\begin{tabular}{|c|c|c|c|c|c|c|c|c|c|c|}
\hline & \multirow{3}{*}{$\begin{array}{l}1998 \\
\text { Fst. }\end{array}$} & \multirow{3}{*}{$\begin{array}{r}1999 \\
- \\
\text { Prel. }\end{array}$} & \multirow{2}{*}{\multicolumn{2}{|c|}{$\begin{array}{c}2000 \\
Q 1-Q 4 \\
\end{array}$}} & \multicolumn{4}{|c|}{2001} & \multirow{3}{*}{$\begin{array}{r}2002 \\
\\
\text { Rev. } \\
\text { Proj. }\end{array}$} & \multirow{3}{*}{$\begin{array}{l}2005 \\
\text { Rev } \\
\text { Proj }\end{array}$} \\
\hline & & & & & \multicolumn{2}{|c|}{ Q1 } & \multicolumn{2}{|c|}{$\mathrm{Ql}-\mathrm{Q4}$} & & \\
\hline & & & Prog & Prel. & Prog & Prel. & Prog & $\begin{array}{l}\text { Rev. } \\
\text { Prog. }\end{array}$ & & \\
\hline & \multicolumn{10}{|c|}{ (hn millions of dalasis) } \\
\hline Revenue and gronls & 919.9 & 944.5 & 1,2050 & $1,117.2$ & 365.0 & 273.4 & $1,347,7$ & $1,374,3$ & $5,480.6$ & $1,631.8$ \\
\hline Domestic revemue & 831.5 & 878.7 & $1,073.7$ & 995.4 & 3360 & 243.2 & $1,211.4$ & $1,135.8$ & $1,262.8$ & 1.402 .0 \\
\hline Tax revenuc & 751.1 & 773.7 & 915.5 & 869.9 & 29000 & 201.4 & $1,030.9$ & 977.0 & $1,088.2$ & $1,220.3$ \\
\hline Direct tax & 185.1 & 201.8 & 221.0 & 223.6 & 63.8 & 69.1 & 240.4 & 250.7 & 275.8 & 303.3 \\
\hline Personal & 76.4 & 81.3 & 88.6 & 90.4 & 25.1 & 28.2 & 94.4 & 101.6 & 111.8 & 122.9 \\
\hline Corporate & 93.7 & 102.2 & 111.4 & 1150 & 26.4 & 32.4 & 121.4 & 128.4 & 141.2 & 155.4 \\
\hline Capital gains & 8.7 & 5.3 & 6.0 & 5.8 & 1.3 & 1.5 & 7.6 & 7.7 & 8.5 & 9.3. \\
\hline Paytoll & 6.3 & 13.1 & 15.0 & 12.4 & 11.0 & 7.0 & 17.0 & 13.0 & 14.3 & 15.7 \\
\hline Indirect tax & 565.0 & 571.8 & 694.5 & 646.3 & 226.2 & 132.3 & 790.5 & 726.3 & 812,4 & 9170 \\
\hline Domestic tax on goods and services & 65.3 & 73.3 & 73.0 & 72.8 & 26.4 & 18.6 & 99.0 & 89.8 & 99.5 & 109.8 \\
\hline Tex cu intemaliond trade & 500.7 & 494.5 & 621.5 & 573.5 & 189.8 & 113.7 & 691.5 & 636.5 & 712.9 & 807.2 \\
\hline Nontax revenue & 80.4 & 105.0 & 158.2 & 125.4 & 46.0 & 41.8 & 180.5 & 158.8 & 174.7 & 181.7 \\
\hline Guants & 88.5 & 55.8 & 131.3 & 121.8 & 30.0 & 30.2 & I36.3 3 & 238.5 & 217.8 & 229.8 \\
\hline Psogram & 25.6 & 11.3 & 60.0 & 60.3 & 160 & 0.0 & 65.0 & 94.2 & 60.0 & 60.0 \\
\hline Projects & 62.9 & 54.5 & 71.3 & 61.5 & 14.0 & 30.2 & 71.3 & 76.3 & 83.0 & 95.0 \\
\hline HIPC tritiative assistarks & D. 0 & 0.0 & 00 & 0.0 & 0.0 & 00 & 0.0 & 68.0 & 74.8 & 74.8 \\
\hline Expenditure and net lending & $1,028.4$ & $1,118.2$ & $3,262.4$ & $1,192: 1$ & 330.5 & 464.6 & $1,367.9$ & 1,433.0 & $1,539.0$ & $1,666.4$ \\
\hline Curent expenditure & 799.8 & 887.0 & 965.2 & 985.8 & 244.2 & 359.9 & 996.9 & 1,190.1 & $1,221.8$ & $1,287.2$ \\
\hline Whages and selaries & 282.9 & 301.7 & 330.0 & 341.2 & 110.6 & 102.8 & 346.5 & 358.3 & 394.1 & 421.7 \\
\hline Other charges & 279.9 & $\mathbf{3 3 6 . 9}$ & 383.9 & 397.4 & 77.3 & $149.5 \mathrm{~V}$ & 410.7 & $\begin{array}{r}473.81 / \\
8.42 /\end{array}$ & 473.9 & 516.7 \\
\hline Interest & 236.9 & 248.3 & 251.4 & 247.3 & 56.3 & 107.6 & 239.7 & 290,0 & 2790 & 274.0 \\
\hline External & 56.4 & 60.9 & 60.1 & 60.2 & 22.5 & 21.0 & 67.7 & 58.0 & 54.0 & 54.0 \\
\hline Domestic & 180.4 & 187.5 & 191.3 & 187.1 & 33.9 & 86.6 & 172.0 & 2320 & 2200 & . $\quad 2200$ \\
\hline \multicolumn{11}{|l|}{ HIPC Injtiative supported } \\
\hline expenditure & 0.0 & 0.0 & 0.0 & 0.0 & 0.0 & 0.0 & 0.0 & 68.0 & 74.8 & 74.8 \\
\hline Capital expenditure and net lending & 228.7 & 231.2 & 297.2 & 206.3 & 86.2 & 104.7 & 371.1 & 242.9 & 317.2 & 379.2 \\
\hline Capilal expertutur: & 259.9 & 261.0 & 342.2 & 245.6 & 86.2 & 104.7 & $\$ 11.1$ & 287.9 & 362.2 & 424.2 \\
\hline Extemnal & 211.2 & 221.0 & 293.4 & 196.7 & 78.1 & 88.8 & 350.1 & 226.9 & 294.3 & 349.2 \\
\hline Larss & $14 B .3$ & 155.2 & 222.1 & 135.2 & 48.1 & 58.6 & 233.8 & 150.6 & 211.3 & 254.2 \\
\hline Grants & 62.9 & 65.8 & 71.3 & 61.5 & 30.0 & 30.2 & 1163 & 76.3 & $\$ 3.0$ & 950 \\
\hline The Gartbas Local Fund & 48.7 & 40.1 & 48.8 & 48.9 & 8.2 & 159 & 61.0 & 61.0 & 67.9 & 75.0 \\
\hline Net iending & -31.2 & .29 .8 & -45.0 & -39.3 & 0.0 & 0.0 & .40 .0 & $-45,0$ & .45 .0 & -45.0 \\
\hline \multicolumn{11}{|l|}{ ONetâl[ balance (cotunitmant basis) } \\
\hline Excluding grants & .197 .0 & $-239,5$ & .188 .7 & -196.8 & 5.5 & -221.4 & .156 .6 & .297 .2 & -276.1 & -264.4 \\
\hline Including errants & -108.5 & -173.7 & -57.4 & -75.0 & 35.5 & -191.2 & -20.3 & -58.8 & .58 .3 & -34.6 \\
\hline \multicolumn{11}{|l|}{ Measures } \\
\hline Adjustment to cash basis (Rlost) & 6.1 & -34.5 & 0.0 & -20.9 & 0.0 & -9.8 & 0.0 & 0.0 & 0.0 & 0.0 \\
\hline Errorts and onissions & $-30,6$ & 0.0 & 0.0 & 0.0 & 0.0 & 0.0 & 0.0 & 0.0 & 0.0 & 0.0 \\
\hline $\begin{array}{l}\text { Orerall balance (cash basis') } \\
\text { Including grants }\end{array}$ & -133.0 & $-208,2$ & -57.4 & .95 .9 & 35.5 & -201.1 & -20.3 & -58.8 & .58 .3 & -34.5 \\
\hline
\end{tabular}

CInternational Monetary Fund. Not for Redistribution 
Table 5. The Garnbia: Central Government Finaneisl Operations, 1998 - 2000 (concluded)

\begin{tabular}{|c|c|c|c|c|c|c|c|c|c|c|}
\hline & \multirow{3}{*}{$\begin{array}{l}1998 \\
\text { Est. }\end{array}$} & \multirow{3}{*}{$\begin{array}{l}1999 \\
\text { Pret. }\end{array}$} & \multirow{2}{*}{\multicolumn{2}{|c|}{$\begin{array}{c}2000 \\
\mathrm{Ql}-\mathrm{Q}^{4}\end{array}$}} & \multicolumn{4}{|c|}{$2 \mathrm{DO}$} & \multirow{3}{*}{$\begin{array}{l}2002 \\
\text { Rev. } \\
\text { Proj }\end{array}$} & \multirow{3}{*}{$\begin{array}{l}2003 \\
\text { Fer. } \\
\text { Proj. }\end{array}$} \\
\hline & & & & & \multicolumn{2}{|l|}{ Q1 } & \multicolumn{2}{|c|}{ Q1.Q4 } & & \\
\hline & & & Prog & Pret, & Prop & Prel. & Prog & $\begin{array}{l}\text { Rev. } \\
\text { Prog. }\end{array}$ & & \\
\hline Financing & 133.0 & 208.2 & 57.4 & 959 & -35.5 & 201.1 & 20.3 & 58.8 & 58.3 & 34.6 \\
\hline Externiai (net) & 54.5 & 30.0 & 40.2 & -45.6 & -3.0 & -22.7 & -26.3 & .88 .1 & 52.5 & 104.8 \\
\hline Borrowing & 148.3 & 155.2 & 222.1 & 135.2 & 48.1 & 58.6 & 233.8 & 150.6 & 211.3 & 254.2 \\
\hline Project & 148.3 & 155.2 & 222.1 & 135.2 & 48.1 & 58.6 & 233.8 & 150.6 & $2 ! 1.3$ & 254.2 \\
\hline Program & 0.0 & 0.0 & 0.0 & 0.0 & 0.0 & 0.0 & $\ldots$ & & .... & $\ldots$ \\
\hline Amortization & -93.8 & -125.2 & -137.0 & -180.8 & -51.1 & .81 .3 & -260.3 & -238.7 & -158.8 & $-149,4$ \\
\hline Debt sctief & $\ldots$ & $\ldots$ & 0.0 & 0.0 & 0.0 & 0.0 & $\ldots$ & 0.0 & $\ldots$ & $\ldots$ \\
\hline Of which: payntent to Alimenta & $\ldots$ & $\ldots$ & -44.8 & -69.0 & 0.0 & -30.0 & $-103,1$ & .108 .5 & $\ldots$ & $\ldots$ \\
\hline Domestic & 78.5 & 178.2 & 17.2 & $i 41.5$ & -32.5 & 223.8 & -29.3 & ] 46.9 & 5.9 & -70.2 \\
\hline Bark & .20 .0 & 71.2 & 272 & 45.0 & $-1 \mathrm{t} .2$ & 206.1 & -40.1 & 140.0 & -30.0 & $\$ 00$ \\
\hline Nonbank & 86.5 & 93.2 & -3.1 & 139.5 & .21 .3 & 32.7 & 9.7 & .23 .1 & 35.9 & 9.8 \\
\hline Mecurnulation of arretrsts & 120 & 13.2 & -25.9 & -190 & 0.0 & -15.0 & 0.0 & 0.0 & 0.0 & 0.0 \\
\hline Repuynetrt of domestic debt & 0.0 & 0.0 & 0.0 & 0.0 & 0.0 & 0.0 & 0.0 & 9.9 & 0.0 & 0.0 \\
\hline Pivatization proceeds & $\ldots$ & $\ldots$ & 24.0 & 24.0 & $\ldots$ & $\ldots$ & 200 & 20.0 & $\ldots$ & $\ldots$ \\
\hline Firancing gap & 0.0 & 00 & 0.0 & 0.0 & 0.0 & 0.0 & 75.9 & 0.0 & 0.0 & 0.0 \\
\hline Memtrandum items: & \multicolumn{10}{|c|}{ (In pereent of GDP, unitss otherwist indirated) } \\
\hline Domestic revenue & 18.8 & 17.8 & 10.9 & 18.5 & 5.7 & 4.1 & 20.4 & 19.2 & 19.5 & 19.9 \\
\hline Total expenditure and net lending & 23.2 & 22.6 & 23.4 & 22.1 & 5.6 & 7.8 & 23.1 & 24.2 & 23.8 & 23.7 \\
\hline Current expenditure & 18.0 & 17.9 & 17.9 & 18.3 & 4.1 & 6.1 & 36.8 & 20.1 & 18.9 & 18.3 \\
\hline Primary chrrent expendifure & 12.7 & 12.9 & 13.2 & 13.7 & 3.2 & 4.3 & 128 & 14.0 & 13.4 & 13.3 \\
\hline Capital expenditure & 5.9 & 5.3 & 6.3 & 4.6 & 1.5 & 1.8 & 6.9 & 4.9 & 5.6 & 6.0 \\
\hline \multicolumn{11}{|l|}{ Overell fiscal deficit } \\
\hline Excluding grants 3 / & -4.4 & -4.8 & -3.5 & -3.6 & 0.1 & -3.7 & -2.6 & -5.0 & -4.3 & .3 .8 \\
\hline Excluding grants & -44 & -4.8 & -3.5 & -3.6 & 0.1 & -3.7 & -2.6 & -39 & .3 .1 & -2.7 \\
\hline Inciuding grants & -2.4 & -3.5 & -1.1 & .1 .4 & 0.6 & -3.2 & -0.3 & $-1,0$ & 0.9 & -0.5 \\
\hline \multicolumn{11}{|l|}{ Primary balance, excluding grants } \\
\hline Hasic primary balance $4 t$ & $5 . ?$ & 4.6 & 6.6 & 4.6 & 2.4 & -0.4 & 7.3 & 3.7 & 4.6 & 5.1 \\
\hline Easic primary balance (in dalasis) 4 f & $25 t .1$ & 229.8 & 356.1 & 247.2 & 139.9 & -25.1 & 433.2 & 219.7 & 257.1 & 358.8 \\
\hline Curent balance & 0.7 & -0.2 & 20 & 1.2 & 1.5 & -2.0 & 3.6 & -4.9 & 06 & 1.6 \\
\hline Stock of domestic detht & 25.9 & 27.0 & 25.6 & 31.4 & 26.0 & 27.8 & 24.6 & 27.7 & 22.7 & 21.0 \\
\hline \multicolumn{11}{|l|}{ Tax on irtenntional trade } \\
\hline In percent of imports, ci.i. & 21.4 & 22.4 & 24.4 & 22.5 & 6.9 & 3.9 & 23.9 & 22.0 & 19.8 & 20,3 \\
\hline Of whisch: duty & 13.8 & 14.3 & 14.8 & 14.1 & 41 & 2.4 & 16.4 & 13.0 & 11.7 & 11.9 \\
\hline \multirow[t]{2}{*}{ Sales tax en imports } & 7.6 & 8.1 & 9.6 & 8.4 & 28 & 1.5 & 9.5 & 9.0 & 8.1 & 8.4 \\
\hline & \multicolumn{10}{|c|}{ (In percent of elurent spendine) } \\
\hline Eduxation $5 t$ & 23.2 & $\ldots$ & 22.4 & 20.3 & $\ldots$ & $\ldots$ & 24.4 & 22.6 & 23.4 & 25,0 \\
\hline Health $5 /$ & 14.5 & $\ldots$ & 4.4 & 12.8 & $\ldots$ & $\ldots$ & 16.2 & 14.6 & 16.3 & 16.7 \\
\hline \multirow[t]{2}{*}{ Defense $5 t$} & 7.7 & $\ldots$ & 5.9 & 5.8 & $\ldots$ & $\ldots$ & 5.8 & 5.3 & 5.2 & 5.0 \\
\hline & \multicolumn{10}{|c|}{ (In trillions of daizsis) } \\
\hline Treasury bills outstanding & $1,020.8$ & $1,201.6$ & $1,300.0$ & $1,564.0$ & $1,300,0$ & 1.519 .5 & $1,300.0$ & 1.512 .0 & $1,500.0$ & 1,5000 \\
\hline
\end{tabular}

Sources: The Gambian anthorities, and Fund staff estimates and projections.

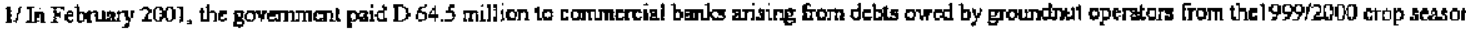

However, this amount will be partly offset by D 12.42 million from the European Union (ELS) stabilization fund and D 9.1 million ficm the recoyery of collateral and pending export proceeds.

$2 /$ Jneludes D 4.2 million from the U.K. Department for International Development and D 1.5 million from the EU for elections scheduled fox late 2001 and early 2002.

$3 /$ Includes HIPC Initiative supported expenditure.

4/ Donestic reverue minns total expenditure and net Jending, excluding interest paynknts and exconally Enanced capital expenditure.

S/Current spending only (wages and other charges).

(CInternational Monetary Fund. Not for Redistribution 
The Gambia. Table 5a: Supplementary Budget for Allocation of HIPC Initiative Interim Debt Relief, 2001

\begin{tabular}{|c|c|c|}
\hline & In millions of dalasis & (As percent of totat) \\
\hline Expenditures by sectors & 68.0 & 100.0 \\
\hline Health (vaccines, mosquito impregnated nets, permethrin and ambulances) & 10.8 & 15.9 \\
\hline Education (teacher training, girls' scholarships and construction of schools) & 14.6. & 21.4 \\
\hline Rural development & 11.7 & 17.2 \\
\hline Agriculture (fertilizer and pesticides) & 4.2 & 6.2 \\
\hline $\begin{array}{l}\text { Artisanal fishing (fish processing centers, promotion of youth } \\
\text { participation in fishing and construction of fish ponds) }\end{array}$ & 0.8 & $1 . \mathrm{I}$ \\
\hline Rural waler supply (construction of 15 hand-dug wells and 30 hand pumps) & 2.2 & 3.2 \\
\hline Rural feeder roads (accessibility to markets, schools and health centers) & 3.7 & 5.4 \\
\hline $\begin{array}{l}\text { Forestry (survey and map production of community forests, including } \\
\text { (promotion of community based eco-tourism) }\end{array}$ & 0.9 & $\begin{array}{l}1.3 \\
0,0\end{array}$ \\
\hline National Envirotiment Agency (training and pomotion) & 0.8 & 1.2 \\
\hline Decentralization (capacity needs assessment) & 0.4 & 0.6 \\
\hline Social Welfare (financial and malerial assistance, including credit grants) & 0.4 & 0.5 \\
\hline Judiciary (establishnent of regional high courts) & 2.6 & 3.8 \\
\hline Public works (relocation of telecommunications services on Seerkunda-Mandinaba road) & 25.1 & 36.9 \\
\hline Central Statistics Department (poverty-related data) & 1.7 & 2.5 \\
\hline Memorandum item: & & As percent of GDP \\
\hline $\begin{array}{l}\text { Fiscal deficit (excluding grants) before enhanced HIPC debt relief } \\
\text { Fiscal deficit (excluding orants) after enhanced HIPC debt relief }\end{array}$ & -229.2 & -3.9 \\
\hline
\end{tabular}

Source: The Gambian authorities 
Tabte 6. The Ganbiz: Monetary Survey, Decenber 1997-December 2003

\begin{tabular}{|c|c|c|c|c|c|c|c|c|c|c|c|}
\hline & \multirow{3}{*}{$\begin{array}{l}1998 \\
\text { Dec. }\end{array}$} & \multirow{3}{*}{$\begin{array}{l}1999 \\
\text { Dee. }\end{array}$} & \multirow{2}{*}{\multicolumn{2}{|c|}{$\begin{array}{l}2000 \\
\text { Dec. }\end{array}$}} & \multicolumn{5}{|c|}{2001} & \multirow{3}{*}{$\begin{array}{l}2002 \\
\text { Dea } \\
\text { Proj }\end{array}$} & \multirow{3}{*}{$\begin{array}{l}2003 \\
\text { Dec } \\
\text { Proj }\end{array}$} \\
\hline & & & & & M & & Tun. & Sep. & Dec. & & \\
\hline & & & Prog & $\begin{array}{c}\text { Prel. } \\
\end{array}$ & Prog. & Prest. & Prog & Prog & Proj. & & \\
\hline \multicolumn{12}{|l|}{ Monetary tutvey } \\
\hline Net for sign assets & 951.6 & 996.0 & $1,047.6$ & $1,098.1$ & $1,075.7$ & $1,051.0$ & $1,24 q .4$ & $1,198.6$ & $1,273.0$ & $1,299.8$ & $1,349.4$ \\
\hline Net domestic assels & 360.0 & 474.3 & 677.0 & 884.3 & 205.2 & 965.9 & 840.0 & 826,5 & 866.9 & $1,026.4$ & $1,186.1$ \\
\hline Domestio orvdit & 481.7 & 6609 & 751.6 & 770.1 & 779.8 & 945.2 & $3,043.1$ & $1,029.6$ & 3,0700 & $1,229.4$ & $1,389.1$ \\
\hline Clains on gorensatent (net) & $-32,8$ & 38.4 & 60.6 & 83,4 & 26.6 & 289.5 & 269.5 & 289.5 & 223.4 & 193.4 & 113,4 \\
\hline Claims on private sector $1 /$ & 514.5 & 622.5 & 690.9 & 686.8 & 753.1 & 655.7 & 773.6 & $740: !$ & 846.6 & $1,036.1$ & $1,275.8$ \\
\hline Other items (net) $3 /$ & -121.7 & -186.6 & -74.5 & 114.2 & -74.5 & 20.7 & $-203.22 f$ & -203.1 & -203.1 & .203 .1 & -203.1 \\
\hline Broad money & 1.311 .6 & 1.470 .3 & $1,724.7$ & $1,982.4$ & 1.780 .9 & 2.016 .9 & $2,084.4$ & $2,025.1$ & $2,139.9$ & $2,326.1$ & $2,535.5$ \\
\hline Cumrency & 347.6 & 379.7 & 413.9 & 540.3 & 452.4 & 584.4 & 604.0 & 473.3 & 535.0 & 581.5 & 633.9 \\
\hline Deposits & 964.0 & 1.090 .6 & $1,310.7$ & 1.442 .1 & $1,328.5$ & $1,432.5$ & $1,480.4$ & $1,551.8$ & $3,605.0$ & $1,744.6$ & $1,901.6$ \\
\hline \multicolumn{12}{|l|}{ Memorandum itents: } \\
\hline \multicolumn{12}{|l|}{ Nontinal GDP } \\
\hline (in millions of dajassis) & $4,433.4$ & $4,922.2$ & $5,357,8$ & $5,391.4$ & $5,805.9$ & $5,928.7$ & $5,928.7$ & $5,928.7$ & $5,928.7$ & $6,462.7$ & $7,041.1$ \\
\hline (percentage charges) & 6.1 & 11.0 & 8.9 & 9.5 & 8.4 & $\ldots$ & $\ldots$ & $\ldots$ & 100 & 9.0 & 9.0 \\
\hline Velocity (GDP/broad moncy) & 3.4 & 3.3 & 3.1 & 2.7 & 3.3 & $\ldots$ & $\ldots$ & $\ldots$ & 2.8 & 2.8 & 28 \\
\hline Reserre money imultiplier & 2.5 & 2.4 & 2.8 & 2.8 & 2.7 & 2.4 & 2.4 & 2.8 & 27 & 2.7 & 2.7 \\
\hline \multicolumn{12}{|l|}{ Arumual percentage shanges } \\
\hline Broad moncy & 10.2 & 12.1 & 17.3 & 34.8 & 0.7 & 14.0 & 14.0 & 16.0 & 7.9 & 8.7 & 9.0 \\
\hline Reserve money & 7.2 & 14.5 & 2.6 & 16.8 & -11.7 & 15.5 & 200 & 7.2 & 14.5 & 8.7 & 90 \\
\hline Credit to priveto sector $3 /$ & 15.0 & 21.0 & 11.0 & 10.3 & 13.7 & -8.0 & 5.3 & 6.9 & 23.3 & 22.4 & 23.1 \\
\hline Total deposits & 16.2 & 13.1 & 20.2 & 32.2 & 0.7 & 11.7 & 14,0 & 16.0 & 11,3 & 8.7 & 9.0 \\
\hline \multicolumn{12}{|l|}{ Percent ratios } \\
\hline Grnencyftroad noney & 26.5 & 25.8 & 24.0 & 27.3 & 25.4 & 29.0 & 29.0 & 23.4 & 25.0 & 25.0 & 25.0 \\
\hline Cuntencyldeposits & 36.1 & 34.8 & 31.6 & 37.5 & 34.1 & 40.8 & 40.8 & 30.5 & 33.3 & 33.3 & 33.3 \\
\hline Depositestroad money & 33.5 & 74.2 & 76.0 & 72.7 & 74.6 & 71.0 & 31.0 & 76.6 & 75.0 & 75.0 & 75.0 \\
\hline Excess reserves/total liabitities & 4.5 & 6.4 & 1.5 & $\cdot 2.3$ & 1.8 & 4.9 & 2.8 & 2.8 & 2.8 & $2 . \mathrm{B}$ & 2.8 \\
\hline Fequivired reserves & 135.0 & 152.7 & 183.5 & 201.9 & 178.1 & 200.5 & 207.3 & 2173 & 224.7 & 244.2 & 266.2 \\
\hline 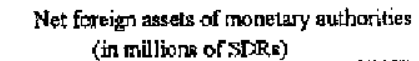 & 66.0 & 66.5 & 62.2 & 66.3 & 63.9 & 60.0 & 62.0 & 59.6 & 63.5 & 64.5 & 67.5 \\
\hline
\end{tabular}

Sources: The Cartabias authorities; and staff estimates and projedticns.

1/ Includes elaims on puiblic enterenies

I/ Exchurge rate in accordanoe with program.

y/ The abrupt movement in phther items nel reflects mainly some technical problent relating to the treatment

of the revaluation account of the central bark and lack of disageregation of the commercial banks'

balance data. Even thougls, to contribution to broad soney growth has bsen ninimal, this probles is expected

to be addressed by the fortheaming STA girsion on monelary stekisties in Augret 2001. 
Table 7. The Gambis: Sumnery Accounts of the Central Bank and Conmarcitil Banks, Decerriban 1998-Decermber 2003

\begin{tabular}{|c|c|c|c|c|c|c|c|c|c|c|c|}
\hline & \multirow{3}{*}{$\begin{array}{c}1998 \\
\text { Dec. }\end{array}$} & \multirow{3}{*}{$\begin{array}{r}1999 \\
\text { Dec. }\end{array}$} & \multirow{2}{*}{\multicolumn{2}{|c|}{$\begin{array}{l}2000 \\
\text { Dec. }\end{array}$}} & \multicolumn{5}{|c|}{2001} & \multirow{3}{*}{$\begin{array}{c}2002 \\
\text { Der. } \\
\text { Proj. }\end{array}$} & \multirow{3}{*}{$\begin{array}{l}200 \\
\text { Drex } \\
\text { Proj }\end{array}$} \\
\hline & & & & & \multicolumn{2}{|c|}{ Mar. } & \multirow{2}{*}{$\begin{array}{l}\text { Jun } \\
\text { Proc }\end{array}$} & \multirow{2}{*}{$\begin{array}{l}\text { Sep. } \\
\text { Frog. }\end{array}$} & \multirow{2}{*}{$\begin{array}{l}\text { Dec, } \\
\text { Froj. }\end{array}$} & & \\
\hline & & & Proge & Pred. & Prog & $\begin{array}{c}\text { Prel. } \\
\text {. }\end{array}$ & & & & & \\
\hline \multicolumn{12}{|l|}{ Central Bank of The Ganbia } \\
\hline Net Ícreign asseta & $1,020.8$ & $1,066.4$ & $1,026.4$ & $3,093.51 /$ & $1,054.5$ & 989.7 & $1,183.1$ & $1,137,3$ & $1,211.7$ & $1,238.4$ & $1,288.1$ \\
\hline (in mistions of SDRs) & 56.0 & 66.5 & 62.2 & 66.3 & 63.9 & 60.0 & 62.0 & 59.6 & 69.5 & 64.9 & 67.5 \\
\hline Foreign assets & $1,166.8$ & $1,253.4$ & $1,344.7$ & $1,359,1$ & $1,372.7$ & $1,254.7$ & $1,489.6$ & $1,508.7$ & ], $6+6.1$ & $1,672.8$ & $1,722.5$ \\
\hline (in millions of SDR) & 75.4 & 78. 1 & 81.5 & 82.4 & 83.2 & 76,0 & 780 & 79.0 & 86.2 & 87.6 & 90.2 \\
\hline Forem liabilifies & -146.0 & $-187,0$ & -318.2 & -265.5 & -318.2 & -265.0 & -306.5 & -371.4 & -434.4 & $-434,4$ & -434. \\
\hline (im millions of SDR) & -9.4 & -11.7 & -19.3 & -16.1 & .193 & -16.1 & -16.1 & .9 .5 & -22.8 & -22.8 & -22.8 \\
\hline Net dotnestic assets & -495.2 & -464.8 & -409.3 & -390.8 & -400.3 & -133.9 & -330.3 & -403.3 & -407.1 & -363.8 & -334.7 \\
\hline Donestis aredit & .557 .2 & -572.5 & -6493 & -778.1 & -640.3 & -488.4 & -461.1 & $-\$ 34.1$ & -597.9 & -494.6 & -465.5 \\
\hline Claims cat the governunent (net) & -545.5 & -545.6 & -592.1 & -732.4 & -583.1 & -454.7 & -405.2 & -478.1 & -481.9 & -438.7 & -405.6 \\
\hline Clain & 262.3 & 262.9 & ... & 252.0 & $\ldots$ & 257.6 & $\ldots$ & $\ldots$ & $\ldots$ & & $\ldots$ \\
\hline Deposits & .807 .7 & -808.5 & $\ldots$ & .984 .4 & $\ldots$ & -712.2 & $\ldots$ & $\ldots$ & $\ldots$ & $\ldots$ & $\ldots$ \\
\hline Chains on privales sector & 20.9 & 21.9 & 22.8 & 22.7 & 22.8 & 24.1 & 24.1 & 24.6 & 24.1 & 24.1 & 24.1 \\
\hline Claims on bunks (net) $y^{t}$ & -32.6 & -490 & -80.0 & -68.4 & -80.0 & -57.8 & -80.0 & -8000 & -80.0 & -800 & -80.0 \\
\hline Of which: entral bank bids & -39.1 & -49.0 & -80.0 & -68.4 & .80 .0 & -57.8 & -80.0 & .80 .0 & -80.0 & .80 .0 & .800 \\
\hline Other items (net) & 61.9 & 107.9 & 2400 & 387.2 & 240.0 & 354.5 & 130.8 & 130.8 & 130.8 & 130.8 & 130.8 \\
\hline Of which: central bartk bills & -25.2 & -32.8 & -5.2 & -1.2 & -5.2 & -4.0 & -4.0 & -4.0 & -4.0 & -4.0 & -4.0 \\
\hline Reserve money & 325.6 & 601.7 & 617.1 & 702.7 & 654,1 & 855,8 & 852.7 & 734,0 & 804.6 & 874.6 & 953.3 \\
\hline Currency oullidg bavks & 347.6 & 329.7 & 413.9 & 540.3 & 452.4 & 584.4 & 604.0 & 473.3 & 535.0 & 581.5 & 633.9 \\
\hline Bank reserres & 178.1 & 221.9 & 203.2 & 1624 & 201.7 & 271.4 & 248.7 & 260.7 & 269.6 & 293.1 & 319.5 \\
\hline Cagh & 14.6 & 32.3 & 29.2 & 35.2 & 29.2 & 35.7 & 35.7 & 35.7 & 35.7 & 35.7 & 35.7 \\
\hline Deposits al the central batk & 153.5 & 189.5 & 194.0 & 127.3 & 172.5 & 235.7 & $2+30$ & 225.0 & 233.9 & 257.4 & 283.7 \\
\hline Required reserves & 135.0 & 152.7 & 183.5 & 201.9 & 178.1 & 200.5 & 207.3 & 217.3 & 224.7 & 244.2 & 265.2 \\
\hline Excoss reserves & 43.1 & 69.3 & 39.7 & -39.5 & 23.6 & 70.9 & 41.5 & 43.5 & 44.9 & 48.8 & 53.2 \\
\hline \multicolumn{12}{|l|}{ Commerciel banks } \\
\hline Net foreign assots & -69.3 & -70.4 & 21.2 & 4.5 & 21.2 & 613 & 61.3 & 61.3 & 61.3 & 61.3 & 6.3 \\
\hline Fotegigl atsats & 32.9 & 126.1 & $\ldots$ & 117.0 & ... & 148.9 & $\ldots$ & $\ldots$ & ... & $\ldots$ & $\ldots$ \\
\hline Fortign liphifitites & -142.2 & -196.5 & $\ldots$ & -112.5 & $\ldots$ & $\$ 7.6$ & $\ldots$ & $\ldots$ & ... & $\ldots$ & ... \\
\hline Net dognesstic assots & 1,0333 & $1,161,0$ & $1,289.5$ & $1,437.6$ & $1,307,2$ & 1.371 .2 & $1,419.1$ & $1,490,5$ & $1,543,6$ & $1,683.3$ & $1,840,3$ \\
\hline Domestis eredit & $1,006.3$ & $1,184.5$ & $\mathrm{I}, 320.9$ & $1,479.8$ & $1,340.1$ & $1,375.7$ & $1,424.2$ & $1,483.6$ & $1,527.8$ & $1,644.0$ & 1.774 .6 \\
\hline Clains on goverament (thet) & 5127 & 583.9 & 652.7 & 815.8 & 609.7 & 744.1 & 674.6 & 767.6 & 705.3 & 5320 & $\$ 22.9$ \\
\hline Claims & 576.6 & 587.9 & 656.7 & 899.7 & 613,7 & 748.7 & 678.6 & 771.6 & 709.3 & 536.0 & 526.9 \\
\hline Depesits & $-4,0$ & -4.0 & -4.0 & $-4,0$ & $-4,0$ & -4.0 & -4.0 & $-4,0$ & -4.0 & -4.0 & -4.0 \\
\hline Claims on privute sector & 489.8 & 591.4 & 664.3 & 652.2 & 726.5 & 558.4 & 676.3 & 642.8 & 749.3 & 938.7 & $1,178.5$ \\
\hline Of which: in foreger currency & 88.7 & 129.0 & & 72.7 & & 72.7 & $\ldots$ & 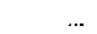 & & & $\ldots$ \\
\hline Clains on public enterprises & 3.9 & 9.2 & 3.9 & 11.9 & 3.9 & 73.2 & 73.2 & 73.2 & 73.2 & 73.2 & 73.2 \\
\hline Reserves & 178.1 & 221.9 & 203.2 & 162.4 & 201.7 & 271.4 & 248.7 & 260.7 & 269.6 & 293.1 & 319.5 \\
\hline Net elains on wentral berik & 32.6 & 49.0 & 80.0 & 68.4 & 80.0 & 57.8 & 80.0 & 80.0 & 80.0 & 80.0 & 80.0 \\
\hline Other items (net) & -183.7 & -294.5 & -314.5 & -273.1 & -314.5 & -333.8 & -333.8 & -333.8 & -333.8 & -3.33 .8 & -333.8 \\
\hline Total deposit liabilities & 954.0 & 1.090 .6 & 1.310 .7 & 1.442 .1 & $1,328.5$ & 1.432 .5 & 1.480 .4 & $1,551.8$ & $1,605.0$ & $1,744.6$ & $1,903.6$ \\
\hline Dornand doposits & 279.0 & 336.3 & 425.0 & $\mathbf{4 4 3 . 3}$ & 368.3 & 462.6 & 478.0 & 501.1 & 518.3 & 563.4 & 514.1 \\
\hline Saving depossits & 462.3 & 556.1 & 602.7 & 705.5 & 610.2 & $689: 2$ & 712.2 & 746.6 & 772.1 & 839.3 & 914.8 \\
\hline Time deposits & 222.7 & 198.1 & 283.0 & 293.3 & 293.9 & 280.8 & 200.2 & 304,3 & 314.6 & 341.9 & 372.7 \\
\hline
\end{tabular}

Sources: The Gambiar autherrities, and waff estimates and projectiona.

$1 /$ Conrerted at fixod rate of D 16.4993 per SDR, as per tecturical remerandun of understanding

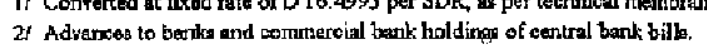

CInternational Monetary Fund. Not for Redistribution 
Tuxie 8. The Gambia: Balance of Payments, $1998-2006$ (In millions of SDRs, unless otharwisc indicated)

\begin{tabular}{|c|c|c|c|c|c|c|c|c|c|c|}
\hline & \multirow{2}{*}{$\begin{array}{c}1998 \\
\text { Est. }\end{array}$} & \multirow{2}{*}{$\begin{array}{c}1999 \\
\text { Est. }\end{array}$} & \multicolumn{2}{|c|}{2000} & \multirow{2}{*}{$\begin{array}{l}2001 \\
\text { Prog. }\end{array}$} & \multirow{2}{*}{$\begin{array}{r}2002 \\
\text { Proj. }\end{array}$} & \multirow{2}{*}{$\begin{array}{r}2003 \\
\text { Proj. }\end{array}$} & \multirow{2}{*}{$\begin{array}{l}2004 \\
\text { Proj. }\end{array}$} & \multirow{2}{*}{$\begin{array}{c}2005 \\
\text { Proj. }\end{array}$} & \multirow{2}{*}{$\begin{array}{l}\text { 2006. } \\
\text { Proj. }\end{array}$} \\
\hline & & & Prog. & Rev, Est. & & & & & & \\
\hline Trade balarice & -56.9 & -53.6 & -54.4 & -50.0 & $-47,9$ & -48.1 & -49.2 & -48.6 & -48.9 & -45.1 \\
\hline Exports, f.c.6. & 95.8 & 87.9 & 95.2 & 959 & 109.1 & 118.4 & 122.5 & 134.9 & 143.9 & 154.8 \\
\hline Groundnuts/groundinut products & 9.6 & 7.3 & 9.5 & 9.8 & 103 & 11.5 & 12.3 & 13.7 & 14.2 & 14.0 \\
\hline Other domestic exports & 5.6 & 4.3 & 4.9 & 6.1 & 7.5 & 9.1 & 10.0 & 11.2 & 12.2 & 13.4 \\
\hline Reexpouts & 80.6 & 76.3 & 80.8 & 799 & 91.3 & 97.8 & 100.1 & 110.1 & 117.5 & 127.4 \\
\hline Imports, f.o.b. & -152.7 & -141.5 & -149.6 & -145.8 & -157.0 & -166.5 & -171.6 & -183.5 & -192.8 & -203.9 \\
\hline For domestic ase & -97.7 & -91.9 & -97.1 & $-9 \$ .2$ & -99.3 & -104.6 & -108.3 & -113.9 & -118.4 & -123.3 \\
\hline Of which: oil produets & -9.2 & -11.6 & -13.7 & -17.7 & -18.3 & -17.6 & -16.1 & -16.3 & -16.4 & -16.9 \\
\hline For reexport & -55.0 & -49.6 & -52.5 & -50.6 & -57.8 & -61.7 & .63 .4 & -69.7 & $.74,4$ & -80.6 \\
\hline Factor ecrvice (net) & -5.2 & -5.0 & -4.6 & -4.8 & -5.0 & -5.2 & $-5,4$ & -5.5 & -5.5 & -5.6 \\
\hline Nonfactor serixe batance & 9.0 & 7.3 & 7.0 & -0.7 & 1.2 & 1.9 & 1.3 & 0.0 & -0.7 & -1.6 \\
\hline Of whioh: travel income & 51.0 & 46.6 & 45.0 & 36.2 & 39.3 & 43.3 & 43.4 & 46.5 & 49.1 & 52.2 \\
\hline Private unrequited transfers (net) & 17.5 & 14.8 & 13.5 & 17.0 & 17.3 & 18.4 & 20.1 & 21.2 & 22.3 & 23.4 \\
\hline Official unrequited transfers (net) & 26.3 & 229 & 259 & 23.7 & 27.0 & 20.6 & 21.8 & 22.5 & 23.3 & 24.0 \\
\hline \multicolumn{11}{|l|}{ Current account balange } \\
\hline Exelucüing official trartsfers & -35.6 & -36.4 & -38.5 & -38.5 & -34.4 & -33.0 & -33.2 & .32 .8 & -32.8 & -32.9 \\
\hline Including official transfers & -9.3 & -13.5 & -12.6 & -14.7 & $-7,4$ & -12.4 & -11.4 & -10.3 & -9.6 & -8.9 \\
\hline Capital account & 16.4 & 13.9 & 10.9 & 15.9 & -3.7 & 3.5 & 4.9 & 5.9 & 7.3 & 8.2 \\
\hline Official loatus (thet) & 3.8 & 3.1 & 3.8 & 4.5 & -9.9 & -3.2 & -1.6 & -1.1 & -0.1 & 0.5 \\
\hline Projest reisted & 10.4 & 100 & 12.5 & 13.2 & 7.4 & 8.8 & 9.4 & 10.1 & 10.6 & 11.1 \\
\hline Anortization & -6.6 & -6.9 & -8.7 & -8.7 & -14.3 & -12.0 & -11.0 & -11.2 & -10.7 & -10.6 \\
\hline Private capital inflow & 12.6 & 12.8 & 7.1 & 11.4 & 6.2 & 6.7 & 6.5 & 7.1 & 7.4 & 7.6 \\
\hline Foreign direst investrnent (nat) & 8.8 & 5.4 & 2.5 & 1.2 & 3.4 & 4.6 & 5.5 & 7.9 & 8.2 & 8.3 \\
\hline Commercial loans (net) & -0.3 & -0.8 & -0.9 & 0.0 & -0.8 & -1.4 & -1.4 & -1.4 & -1.4 & -1.3 \\
\hline Short-term capital (net) $1 /$ & -2.4 & 0.1 & 1.3 & 8.7 & 3.0 & 3.0 & 1.8 & 0.0 & 0.0 & 0.0 \\
\hline Suppliers' credits & 6.5 & 8.1 & 4.2 & 1.5 & 0.5 & 0.5 & 0.5 & 0.6 & 0.6 & 0.6 \\
\hline Overall balanes & 7.1 & 2.3 & -1.8 & 1.2 & -11.2 & -8.9 & 6.5 & -4.3 & -2.3 & -0.8 \\
\hline Finarcing & -7.1 & -2.3 & 1.8 & -1.2 & 11.2 & 3.9 & 3.0 & 0.8 & -0.7 & -2.2 \\
\hline Change in grosg official reserves (increase $=-$ ) & -6.4 & -2.7 & -3.5 & -6.4 & 1.6 & -6.3 & -5.4 & -6.5 & $-6,3$ & -6.6 \\
\hline Repurchsses/repaymejts (INIF) & $-4,0$ & -3.1 & -1.7 & -1.7 & -0.5 & -0.4 & 0.1 & -0.8 & -1.8 & -3.2 \\
\hline Punthasesloats (TMF) & $\mathbf{3 . 3}$ & 3.4 & 6.9 & 6.9 & 6.7 & 0.0 & 0.0 & 0.0 & 0.0 & 0.0 \\
\hline London Club & 0.0 & 0.0 & 0.0 & 0.0 & 0.0 & 0.0 & 0.0 & 0.0 & 0.0 & 0.0 \\
\hline Debt tejief 2 & 0.0 & 0.0 & 0.0 & 0.0 & 3.4 & 5.6 & 5.0 & 4.7 & 4.4 & 4.5 \\
\hline Fingreing gap & 0.0 & 0.0 & 0.0 & 0.0 & 0.0 & 5.0 & 3.5 & 3.5 & 3.0 & 3.0 \\
\hline \multicolumn{11}{|l|}{ Mennorandum ilems: } \\
\hline \multicolumn{11}{|l|}{ Curent account balance (in percent of GDP) } \\
\hline Excluding official transfers & -11.6 & -11.5 & -12.3 & -12.0 & -11.8 & -11.2 & -10.4 & -10.3 & -10.3 & -9.9 \\
\hline Including officjal transfers & $-3,0$ & -4.3 & -4.0 & -4.6 & -2.6 & -4.2 & -3.6 & -3.2 & -2.9 & -2.7 \\
\hline \multicolumn{11}{|l|}{ Gross afficial reserve (end of period) } \\
\hline In millfons of SDRs & 75.4 & 78.1 & 81.6 & 82.5 & 80.9 & 87.2 & 92.6 & 99.1 & 105.4 & 112.0 \\
\hline In months of imports, a.i.f. & 5.1 & 5.8 & 5,6 & 5.9 & 5.3 & 5.4 & 5.5 & 5.6 & 5.6 & 5.6 \\
\hline \multicolumn{11}{|l|}{ In months of imports, c.i.f. } \\
\hline Over the next 12 months & 4.8 & 5.4 & 4.9 & 5.4 & 5.0 & 4.9 & 5.2 & 5.3 & 5.3 & 5.3 \\
\hline Flus all other services payments & 3.9 & 4.5 & 4.2 & 4.6 & 4.2 & 4.1 & 4.4 & 4.5 & 4.5 & 4.4 \\
\hline \multicolumn{11}{|l|}{ Debt-service ratio $3 / 4 /$} \\
\hline Intiuding the Fund & 11.4 & $1 \mathrm{~L} .4$ & 9.4 & 8.5 & 15.6 & 11.7 & 10.1 & 9.6 & 9.2 & 9.2 \\
\hline Excluding the Fund & 8.5 & 8.8 & 8.0 & 7.0 & 15.1 & 10.8 & 9.9 & 9.1 & B.2 & 7.5 \\
\hline
\end{tabular}

Sources: The Gambian authorites; and staff estimates and projections.

$1 f$ Including amors and omissions.

2/ Forgiversess of a D 7.2 million interest payment by Tawwan Frowince of China,

3/ In percent of exports and travel incame.

4/ In 2001, the increase in debt service mainly reflects payments to Alimenta (the lasti pryment will be in July 2001). 
Toble 9. The Gambia: Itcone and Social Indicators, 1970 - 2003

\begin{tabular}{|c|c|c|c|c|c|c|c|c|c|c|}
\hline & \multirow{3}{*}{$\begin{array}{l}\text { Unit of } \\
\text { Measurement }\end{array}$} & \multicolumn{3}{|c|}{ Latest Single Year } & \multirow{3}{*}{1998} & \multirow{3}{*}{1999} & \multirow{3}{*}{2000} & \multirow{3}{*}{2001} & \multirow[b]{2}{*}{2002} & \multirow{3}{*}{2003} \\
\hline & & \multirow[t]{2}{*}{$1970-75$} & \multirow[t]{2}{*}{1980.85} & \multirow[t]{2}{*}{$1992-97$} & & & & & & \\
\hline & & & & & & & & & Proj. & \\
\hline \multicolumn{11}{|l|}{ Population } \\
\hline Totsil poppulationt & Millions & 0.5 & 0.7 & 1.2 & 1.2 & 1.3 & 1.3 & 1.4 & 1.4 & 1.4 \\
\hline Population (rnidyear) & Millions & 0.5 & 0.7 & 1.2 & 1.2 & 1.3 & 1.3 & 1.3 & 1.4 & 1.4 \\
\hline Population Erowth rate & Percent & 3.3 & 3.0 & 2.8 & 30 & 4.2 & 30 & 3.0 & 3.0 & 3.0 \\
\hline Total fertility rate & Births per woman & 6.5 & 6.5 & 5.7 & $\ldots$ & $\ldots$ & $\ldots$ & $\ldots$ & $\ldots$ & $\ldots$ \\
\hline \multicolumn{11}{|l|}{ Powerty } \\
\hline Total & Percent of population & $\ldots$ & $\ldots$ & 40,0 & 70.0 & $\ldots$ & $\ldots$ & $\ldots$ & $\ldots$ & $\ldots$ \\
\hline Utan poverty & Percent of population &.. & $\ldots$ & 37.0 & 56.3 & $\ldots$ & $\ldots$ & $\ldots$ & $\ldots$ & $\ldots$ \\
\hline Rural poverty & Percent of population & $\ldots$ & $\ldots$ & 41.0 & 79.0 & $\ldots$ & $\ldots$ & $\ldots$ & $\ldots$ & $\ldots$ \\
\hline National head count index & Percent of population & $\ldots$ & $\ldots$ & 64.0 & $\ldots$ & $\ldots$ & $\ldots$ & $\ldots$ & $\ldots$ & $\ldots$ \\
\hline \multicolumn{11}{|l|}{ Ineame } \\
\hline GNP per capita & U.S. dollars & 230.0 & 2400 & 340.0 & $3 \$ 6,8$ & 340.0 & 3590 & 380.2 & 402.5 & 423.0 \\
\hline Index of real wages & $1974=100$ & $\ldots$ & $\ldots$ & $\cdots$ & $\cdots$ & $\ldots$ & $\ldots$ & $\ldots$ & ... & $\ldots$ \\
\hline Agricultura! & $1974=100$ & $\ldots$ & $\ldots$ & $\ldots$ & $\ldots$ & $\ldots$ & $\ldots$ & $\ldots$ & $\ldots$ & $\ldots$ \\
\hline Nonagricultural & $3974=100$ & $\ldots$ & $\ldots$ & $\ldots$ & $\ldots$ & $\ldots$ & $\ldots$ & $\ldots$ & $\ldots$ & $\ldots$ \\
\hline Consurner pice index & $1974=100$ & 1260 & 3840 & $1,441,3$ & $1,457.3$ & $1,523.8$ & $1,525.7$ & $1_{2} 579.1$ & $1,618.5$ & $1_{r} 659.0$ \\
\hline Food price index & $1974=100$ & $\cdots$ & & 3,5127 & $1,565.8$ & $1,630.8$ & $1,632.6$ & $1,689.7$ & $1,732.0$ & 1.775 .3 \\
\hline \multicolumn{11}{|l|}{ Soctal indicators } \\
\hline \multicolumn{11}{|l|}{ Goverrment cusent expenditure } \\
\hline Edutwation & Percent of GDP & 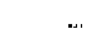 & $\ldots$ & $\ldots$ & $\ldots$ & 3.0 & 3.0 & 3.2 & 3.2 & 3.4 \\
\hline Health & Percent of GDP & $\ldots$ & $\ldots$ & $\ldots$ & --- & 1.8 & 1.9 & 21 & 2.1 & 21 \\
\hline \multicolumn{11}{|l|}{ Net primary school enrolhment } \\
\hline Total & Percent of age group & 21.0 & 62.0 & 65.0 & $\ldots$ & $\ldots$ & $\ldots$ & $\ldots$ & $\ldots$ & $\ldots$ \\
\hline Mole & Peroant of age group & $\ldots$ & 77.0 & 72.0 & $\ldots$ & $\ldots$ & $\ldots$ & $\ldots$ & $\cdots$ & $\ldots$ \\
\hline Female & Percent of age group & $\ldots$ & 48.0 & 57.0 & $\cdots$ & $\cdots$ & $\cdots$ & $\ldots$ & $\ldots$ & $\ldots$ \\
\hline \multicolumn{11}{|l|}{ Access to safe wrater } \\
\hline Total & Percant of population & 12.0 & 45.0 & 500 & $\ldots$ & $\cdots$ & $\ldots$ & $\ldots$ & $\ldots$ & $\ldots$ \\
\hline Lirban & Percent of population & 97.0 & 100.0 & 640 & $\ldots$ & $\ldots$ & $\ldots$ & $\ldots$ & $\cdots$ & $\ldots$ \\
\hline Fural & Pereent of population & 3.0 & 33.0 & 39.0 & $\ldots$ & $\ldots$ & $\cdots$ & $\cdots$ & $r$ & $\cdots$ \\
\hline \multicolumn{11}{|l|}{ Erumunization rate } \\
\hline Measles & Percent under 12 months & $\ldots$ & 75.0 & 91.0 & $\cdots$ & $\ldots$ & $\cdots$ & $\cdots$ & $\cdots$ & $\ldots$ \\
\hline DPT & Percerst under 12 inonths & $\ldots$ & 77.0 & 96.0 & $\ldots$ & $\ldots$ &.- & $\cdots$ & $\cdots$ & $\ldots$ \\
\hline Children's (under age of 5 ) & & & & & & & & & & \\
\hline malrullrition rate & Percent & $\cdots$ & 20.0 & 26.0 & $\cdots$ & $\cdots$ & $\cdots$ & $\cdots$ & $\therefore$ & $\cdots$ \\
\hline Life expectancy at birth & & & & & & & & & & \\
\hline Total & Years & 37.0 & 41.0 & 53.0 & 53.2 & $\ldots$ & $\ldots$ & $\ldots$ & $\ldots$ & $\cdots$ \\
\hline Male & Years & 36.0 & 39.0 & $\$ 1.0$ & 51.4 & $\ldots$ & $\ldots$ & $\ldots$ & $\ldots$ & $\ldots$ \\
\hline Female & Years & 390 & 43.0 & 55.0 & $\$ \$ .0$ & $\ldots$ & $\ldots$ & $\ldots$ & $\because$ & $\therefore$ \\
\hline Mortaling & & & & & & & & & & \\
\hline Infane mortality rate & Per thousand live births & 179.0 & 1540 & 78.0 & 76.4 & $\ldots$ & $\ldots$ & $n$ & $\ldots$ & .. \\
\hline Under ase of 5 mortality rate & Per thousand live births & $3] 9.0$ & 2160 & 110.0 & $\ldots$ & $\ldots$ & $\ldots$ & $\ldots$ & $\cdots$ & $\cdots$ \\
\hline Male & pa thousand live births & $\ldots$ & $\ldots$ & 138,0 & $\ldots$ & $\cdots$ & $\ldots$ & $\cdots$ & $\ldots$ & $\ldots$ \\
\hline Female & Per thoutsand live births & $\cdots$ & $\cdots$ & 120.0 & $\cdots$ & $\cdots$ & $\cdots$ & $\cdots$ & $\ldots$ & $\cdots$ \\
\hline Adzult (ages 15-59) martality rate & Per thourand population & $\cdots$ & $\ldots$ & $\cdots$ & $\ldots$ & $\cdots$ & $\cdots$ & $\ldots$ & $\ldots$ & $\ldots$ \\
\hline Male & Per thoustand population & 655.0 & 584.0 & 404.0 & 408.0 & $\leadsto$ & $\ldots$ & $\ldots$ & $\ldots$ & $\ldots$ \\
\hline Fente & Pe thousand population & 519.0 & 466.0 & 339.0 & 3440 & $\cdots$ & $\ldots$ & $\cdots$ & $\cdots$ & $\cdots$ \\
\hline Matemal mortality racio & Per thousand live births & $\ldots$ & ] 5.0 & 11.0 & $\ldots$ & $\ldots$ & $\cdots$ & $\ldots$ & $\ldots$ & $\ldots$ \\
\hline
\end{tabular}

Sounces: World Eank; United Nations; the Gambian authorities; and staff estimates and projections. 


\section{The Gambia: Technical Memorandum of Understanding}

May 16, 2001

\section{INTRODUCTION}

1. This memorandum sets out the understandings between the Gambian authorities and staff of the International Monetary Fund (IMF) regarding the definitions of quantitative and structural performance criteria and benchmarks for the third annual arrangement under the Poverty Reduction and Growth Facility (PRGF), as well as the related reporting requirements. A table with the latest actual data for the monetary aggregates, as well as the preliminary estimates for March 2001 used for the derivation of the flows for the program period, is attached (Tables 6 and 7 ).

\section{Quantitative Performance Criteria; Definitions and Reporting Standards}

\section{A. Net International Reserves of the Central Bank of The Gambia}

2. Definition. Net international reserves (NIR) are defined as reserve assets less liabilities to foreign residents of maturity of one year or less and less borrowing from the IMF. Gold holdings will be valued at U.S. dollar market prices, together with foreign currency holdings, at the bilateral exchange rates prevailing on March 31, 2001. The NIR shall be converted into dalasis at the exchange rate prevailing on March 31, 2001 (estimated at D 19.087 per SDR). Reserve assets are defined for this purpose as external assets readily available to, or controlled by, the Central Bank of The Gambia (CBG). Pledged or otherwise encumbered reserves assets, including, but not limited to, reserves assets used as collateral or guarantee for third-party external liability, are to be excluded.

3. Adjustment clauses. The floor on the net international reserves of the central bank will be adjusted upward (downward) by the amount of disbursed extemal budgetary support (comprising non-project-related loans and grants) at the end of each quarter in excess (in shortfall) of the programmed amounts in the budget (Appendix $I_{2}$ Table 2).

4. Supporting material. Net international reserves of the central bank will be transmitted on a weekly basis within ten days of the end of each week; the net foreign assets of the commercial banks and external budgetary support will be transmitted on a monthly basis within six weeks of the end of each month.

\section{B. Net Domestic Assets of the Central Bank}

5. Definition. The net domestic assets of the central bank are defined as the difference between reserve money (the sum of currency outside banks and all deposits of the commercial banks, excluding deposits of the central government) and the net foreign assets 
of the central bank, converted at the foreign exchange rate specified in paragraph 2. Net foreign assets are defined as NIR plus other claims on, and liabilities to, foreign residents.

6. Adjustment clauses. The ceiling on net domestic assets of the central bank will be adjusted downward (upward) by the amount of disbursed external budgetary support (comprising non-project-related loans and grants) at the end of each quarter in excess (in shortfall) of the programmed amounts in the budget (Appendix I, Table 2).

7. Supporting material. Net domestic assets of the central bank will be transmitted on a monthly basis within four weeks of the end of each month.

\section{Net Claims on the Central Government by the Central Bank of The Gambia}

8. Definitions. The net claims on central government by the central bank are defined as claims on the central government by the central bank less deposits of the central government with the central bank.

9. Adjustment clauses. The ceiling on net claims on the central government by the central bank will be adjusted downward (upward) by the amount of disbursed external budgetary support (comprising non-project-related loans and grants) at the end of each quarter in excess (in shortfall) of the programmed amounts in the central government budget (Appendix I, Table 2).

10. Supporting material. Data on cumulative government revenue and expenditure, on the net central government position with the central bank, and on treasury bills outstanding, as well as data on external loans and grants to the government, will be transmitted on a monthly basis within six weeks of the end of each month.

\section{Basic Primary Balance of the Central Government}

11. The basic primary balance is defined as government domestic revenue (tax and nontax) minus total expenditure and net lending, excluding interest payments and externally finaneed capital expenditure.

\section{E. External Payments Arrears}

12. Definition. External payments arrears are defined as the stock of external arrears on loans contracted or guaranteed by the public sector (as defined below in paragraph 14), except on debts subject to rescheduling or a stock-of-debt operation.

13. Supporting material. An accounting of nonreschedulable external arrears by creditor countries (if any), with detailed explanations, will be transmitted on a monthly basis within four weeks of the end of each month. This accounting would include, separately, arrears 
owed by the central government and other public sector entities to Paris Club creditors, nonParis Club creditors, and other creditors.

\section{F. New Nonconcessional External Debt Contracted or Guaranteed by the Public Sector}

14. Definitions. In this memorandum, the public sector consists of the central and regional governments and other public agencies, including the Central Bank of The Gambia. This performance criterion is on the contracting or guaranteeing of external debt with original maturity of 1-12 years by the public sector. ${ }^{1}$ Excluded from this performance criterion is debt with a grant element of at least 35 percent. The grant element is to be calculated by using currency-specific discount rates reported by the OECD (commercial interest reference rates): for maturities of less than 15 years, the grant element will be calculated based on six-month averages of commercial interest rates, and, for maturities longer than 15 years, the grant element will be calculated based on ten-year averages,

15. Supporting material. A comprehensive record, including a loan-by-loan accounting of all new concessional and nonconcessional debt contracted or guaranteed by the public sector, with detailed explanations, will be transmitted on a quarterly basis within four weeks of the end of each quarter. Nonconcessional external debt over one year includes financial leases and other instruments giving rise to external liabilities contingent or otherwise on concessional terms.

\section{G. Outstanding Stock of External Public Debt}

16. This performance criterion is the outstanding stock of external debt with original maturity of less than one year owed or contracted by the public sector. ${ }^{2}$ Excluded from this performance criterion are normal import-related credits.

17. Supporting material. A comprehensive record of all external debt with original maturity of less than on year owed or contracted by the public sector, with detailed explanations, will be transmitted on a quarterly basis within four weeks of the end of each quarter.

${ }^{1}$ This performance criterion applies not only to debt as defined in point no. 9 of the "IMF Guidelines on Performance Criteria with Respect to Foreign Debt" (adopted by the Executive Board of the Fund on August 24, 2000), but also to commitments contracted or guaranteed for which value has not been teceived.

${ }^{2}$ The term "debt" has the meaning set forth in point no. 9 of the "TMF Guidelines on Performance Criteria with Respect to Foreign Debt," adopted on August 24, 2000. 


\section{Prior actions and Quantitative Performance Criterla and benchmarks}

18. To monitor policy implementation, a prior action and a number of quantitative benchmarks have been proposed over the course of the program, as well as quantitative performance criteria and benchmarks for enc-September 2001 (see Appendix I, Table 1). The prior actions entail (a) the submission to parliament of the supplementary budget measures, including the contingency budget to be funded from interim debt relief under the enhanced HIPC Initiative; and (b) the establishment and implementation of a comprehensive accounting framework to monitor expenditure on poverty reduction, including expenditure funded from enhanced HIPC Initiative debt relief. The proposed benchmarks for end-June 2001 will comprise the following: (a) a ceiling on net bank credit to the central government; (b) a ceiling on net domestic assets of the Central Bank of The Gambia; (c) a floor on the basic primary balance of the central government, defined to exclude interest payments and foreign-financed investment spending; (d) the nonaccumulation of external payments arrears; (e) a floor on net official international reserves; ( $f$ ) a ceiling on new nonconcessional external loans contracted or guaranteed by the public sector for maturities of 1-12 years; and (g) a zero ceiling on the outstanding stock of short-term external public debt owed or contracted by the public sector (excluding normal import-related credits). The criterion on the nonaccumulation of external payments arrears will be applied on a continuous basis. Limits on items (a)-(g) above for end-September 2001 will serve as quantitative performance criteria. In addition, the reform measures indicated in Appendix I, Table 2 have been adopted as structural performance criteria and benchmarks for the program.

\section{Structural Performance Criteria and Benchmarks}

19. Lastly, the authorities will notify the African Department of the Fund of developments with respect to structural performance criteria and benchmarks as soon as they occur. The authorities will provide the following documentation, according to dates in Appendix I, Table 2, elaborating the steps taken to (a) establish and begin to implement a comprehensive accounting framework to monitor expenditure on poverty reduction, including expenditure funded from enhanced HIPC Initiative debt relief; (b) extend the mandate of the external debt unit of the Department of State for Finance and Economic Affairs and have it start to also compile publicly guaranteed external debt, other external contingent liabilities of the government, and domestic debt; (c) complete the full installation of the automated system for customs data (ASYCUDA II) and use it also to generate trade data reclassified by economic categories; (d) complete the rebasing of the national accounts to 1998; (e) establish the regulatory framework, issue guidelines, and authorize commercial banks to establish foreign currency deposits; and (f) introduce the book-entry system for treasury bill auctions and finalize plans for introducing longer-term treasury bills and goverument bonds. 


\section{Other Elements of The Program}

\section{A. Program-Monitoring Committee}

20. Definition. The Gambian authorities shall establish a program-monitoring committee composed of senior officials from the Department of State for Finance and Economic Affairs (DOSFEA), the CBG, and other relevant agencies. The committee shall be responsible for monitoring the performance of the program, recommending policy responses, informing the Fund regularly about the progress of the program, and transmitting the supporting materials necessary for the evaluation of performance criteria and benchmarks. The committee shall provide the Fund with a progress report on the program on a monthly basis within four weeks of the end of each month, using the latest available data.

\section{DATA Requirements}

\section{A. Production and Prices}

21. Reporting standard. The monthly disaggregated consumer price index will be transmitted within four weeks of the end of each month.

\section{B. Government Accounts Data}

22. Reporting standard. A consolidated budget report of the central government comprising (a) the revenue data by each major item, including that collected by the Commissioner of Taxes and the customs department, as well as privatization's transfers to the budget; (b) details of the recurrent and capital expenditure of the central government; (c) details of budget financing (domestic and external), which will be transmitted on a monthly basis within six weeks of the end of each month; and (d) details on the government's outstanding arrears outstanding, as of end-March 2001, including payments and other arrangements to discharge them (these data will be transmitted on a monthly basis within six weeks of the end of each quarter). The government's arrears amounted to D 23 million as of end-March 2001, while public enterprises owed the government about D39 million.

\section{Monetary Sector Data}

23. Reporting standard. The balance sheet of the central bank and the consolidated balance sheets of the commercial banks will be transmitted on a monthly basis within six weeks of the end of each month. The results of the treasury bill anctions will be transmitted on a biweekly basis within five business days. The stocks of government securities, balances in the divestiture account, detailed information on interbank loans (terms, duration, and participating institutions), and interest rate developments will be transmitted on a monthly basis within two weeks of the end of each month. 


\section{External Sector Data}

24. Reporting standard. The following standard will be adhered to: (a) the interbank market exchange rate, as the simple average of the daily-weighted average buying and selling rates, will be transmitted on a weekly basis within five business days of the end of the week; (b) the results of foreign exchange auctions (on a weekly or more frequent basis) will be transmitted on a weekly basis within five business days of the end of each week; and (c) balance of payments data will be transmitted on a quarterly basis within six weeks of the end of each quarter. 


\section{The Gambia: Relations with the Fund}

(As of June 30, 2001)

Membership Status: Joined 09/21/1967; Article VIII

\section{General Resources Account}

Quota

Fund holdings of currency

Reserve position in Fund

\section{SDR Department}

Net cumulative allocation

Holdings

\section{Outstanding Purchases and Loans}

Enhanced Structural Adjustment Facility (ESAF)/

Poverty Reduction Growth Facility (PRGF)

arrangements

$\begin{array}{rr}\text { SDR Million } & \% \text { Quota } \\ 31.10 & 100.0 \\ 29.62 & 95.2 \\ 1.48 & 4.8\end{array}$

SDR Million $\%$ Allocation

$5.12 \quad 100.0$

$0.14 \quad 2.7$

SDR Million \% Quota

13.83

44.5

Financial Arrangements

Type

Approval

Expiration

Date Date

Approved

Amount

Drawn

\section{ESAF/PRGF}

$06 / 29 / 1998 \quad 06 / 31 / 2001$

(SDR Million)

(SDR Million)

ESAF

Structural Adjustment Facility (SAF)

10.86

Projected Obligations to the Fund (SDR million; based on existing use of resources and present holdings of SDRs):

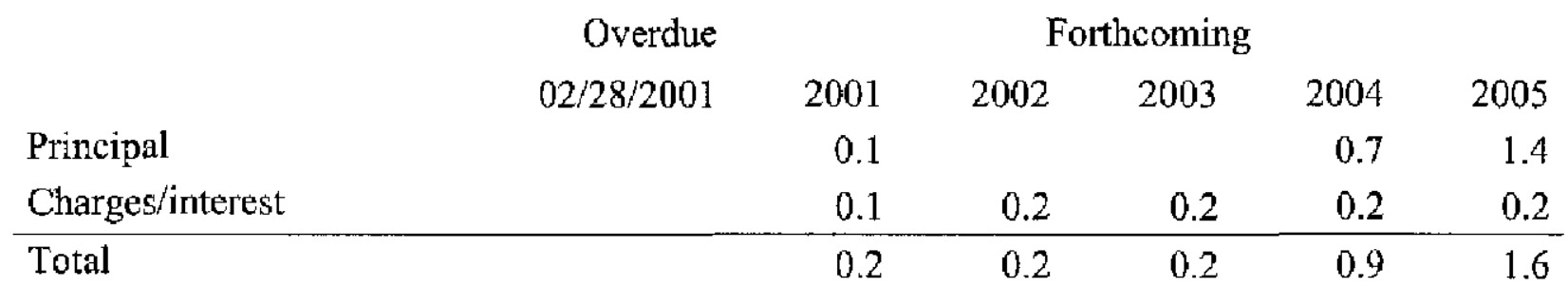

\footnotetext{
${ }^{1}$ Excluding debt-service payments to the Saudi Fund for Development. The projection of charges and interest assumes that overdue principal at the report date (if any) will remain outstanding, but that forthcoming obligations will be settled on time.
} 


\section{Exchange rate arrangement}

Prior to January 20, 1986, the Gambian currency, the dalasi, was pegged to the pound sterling at a rate of D $5=£ 1$. On January 20,1986 , an interbank market for foreign exchange was introduced, and since then the exchange rate has been determined by market forces. At endMarch 2001, the midpoint exchange rate in the interbank market was D 15.0505 per U.S. dollar.

The Gambia accepted the obligations of Article VIII, Sections 2, 3, and 4 on January 21, 1993.

\section{Last Article IV Consultation}

The 2000 Article IV consultation (EBS/00/129; 7/7/00) was concluded by the Executive Board on July 19, 2000. The Gambia is on the standard 12-month cycle for Article IV consultations.

\section{Technical assistance}

A technical assistance mission from STA on Monetary and Financial Statistics visited The Gambia in August 2001.

An MAE short-term expert visited Banjul in May 2001 to assist the authorities in designing appropriate operational, prudential, and policy safeguards (including assessing the adequacy of existing legislation) for the introduction of foreign currency-denominated accounts.

An MAE short-term expert visited Banjul in April 2001 to assist the authorities in setting up a book-entry system.

A technical assistance mission from STA on balance of payments statistics visited The Gambia in September 2000.

An MAE short-term expert visited Banjul in May 2000 to assist the authorities in setting up a short-term liquidity forecasting system.

A long-term Fund resident budget expert is assisting the authorities in strengthening budgetary expenditure reporting and control from August 2000 through August 2001.

An STA mission visited The Gambia in November 1999 to review the statistical collection in order to develop a GDDS (General Data Dissemination System) metadata for The Gambia.

An FAD technical assistance mission-aimed at assisting the authorities in expenditure management, budget execution issues, cash and debt management, short-term financial planning, fiscal reporting, and information systems-visited The Gambia in early September 1999. 
An MAE short-term expert visited Banjul in November 1999 to assist the authorities in designing appropriate operational, prudential, and policy safeguards (including assessing the adequacy of existing legislation) for the introduction of foreign currency-denominated accounts in the banking system.

A technical assistance mission from STA on the balance of payments statistics visited The Gambia in June-July 1999.

A technical assistance mission from STA on the national accounts visited The Gambia in November-December 1998.

An MAE technical assistance mission took place in August 1998 to assist the Central Bank of The Gambia in developing market-based monetary policy instruments and to review its program for strengthening banking supervision.

An MAE technical expert provided assistance to the central bank in foreign exchange operations in December 1996.

A joint FAD/United Nations Development Program (UNDP) technical assistance mission took place in January-February 1996 to help establish a system for monitoring the financial operations of public enterprises.

An MAE technical assistance mission on monetary management and bank supervision visited The Gambia in January-February 1994.

A joint FAD/UNDP technical assistance mission on government accounting procedures and the computerization of these accounts took place in February-March 1993.

A technical assistance mission from STA on government finance statistics visited The Gambia in November 1992.

\section{Resident Representative}

There is currently no provision for a resident representative in The Gambia. 


\section{The Gambia: Relations with the African Development Bank ${ }^{1}$}

(As of March, 2001)

1. The African Development Bank (AfDB) started lending to The Gambia in 1974. As of June 2000, the AfDB Group ${ }^{2}$ had provided financial assistance arnounting to SDR 168.92 million in support of 38 operations. This assistance consists of five loans from AfDB resources amounting to SDR 21.34 million, twenty-two loans totaling SDR 128.58 million from African Development Fund (AfDF) resources, two loans from Nigeria Trust Fund (NTF) resources totaling SDR 6.5 million, and nine grants totaling SDR 12.50 million from the Technical Assistance Fund (TAF) of AfDF resources.

2. The assistance, which has been provided since 1990, includes nine AfDF loans and eight TAF grants. The loans have been provided to finance (a) improvement of the Banjul port infrastructure to meet the handling of increased cargo tonnage; (b) an education project aimed at improving primary teacher training and capacity building in the Ministry of Education; (c) rehabilitation of health-training facilities aimed at strengthening their capacity by expanding and improving the technical skills of students graduating from the School of Public Health and the School of Nursing and Midwifery, as well as at improving primary health care delivery through support to maternal and child health care programs, and training of traditional birth attendants and community health workers; (d) a structural adjustment program in support of policy reforms; (e) a Lowlands Agriculture Development Program aimed at improving food security for the poor smallholder rice growers; (f) a poverty reduction project addressing several aspects of capacity building for the poor and women by strengthening local public services for the poor to grant financing for smail-scale projects, and providing loan funds for income-generating activities, particularly women-managed microenterprises; $(\mathrm{g})$ a health sector rehabilitation project aimed at strengthening institutional capacity of the Department of State for Health, Social Welfare and Women's Affairs at divisional and central levels, thus enhancing the capability to plan, implement, and manage the delivery of improved health care services; (h) a periurban horticultural project aimed at improving horticultural and other income-generating activities of women in the greater Banjul area; and (i) a skills development project geared toward increasing economic productivity of rural women in the villages (WID $I$ ). The grants were provided for the (a) institutional strengthening of the Ministry of Works and Communications and the carrying out of a feasibility study for an eastem road link (Essau-Farafenni road); (b) a skills development project (WID I) geared at improving the economic productivity of rural women; (c) a technical assistance component of the skills development project mentioned above (WID III); (d) feasibility studies for rural electrification and livestock development; (e) a health services requirements study undertaking a comprehensive analysis of requirements for more efficient and cost-effective health care delivery services; (f) a coastal protection study to examine the extent of sea encroachment and degradation of the coastline in Banjul and

\footnotetext{
${ }^{1}$ Prepared by AfDB staff.

${ }^{2}$ The AfDB Group consists of the African Development Bank, the African Development Fund, and the Nigeria Trust Fund.
} 
recommend mitigating measures; and (g) a capacity-building operation to strengthen the project and debt-management capability of the Department of State for Finance and increase the supply of qualified female teachers in the basic education cycle.

3. The AfDB Group lending strategy for The Gambia recognizes the poverty pervading the Gambian population, the shortage of administrative and managerial skills, and the need to develop private sector activity. Thus for the ADF VII Programming Cycle (1999-2001), the AfDB Group will pursue a lending strategy that supports the government's implementation of a comprehensive social program within its overall development agenda. The strategy includes the provision of assistance directed at poverty reduction and pursuance of economic and administrative reforms to promote private sector participation. Assistance for poverty reduction efforts will be carried out through direct pro-poor interventions via new operations in the agriculture and social sectors and rural infrastructure, as well as through analytical and financial support for diversifying the economy and increasing private sector involvement in new economic activities, in order to speed up job creation. 


\section{The Gambia: Relations with the World Bank Group}

(As of March 31, 2001)

1. The World Bank, through IDA, has assisted the government in pursuing three main objectives: (a) establishment of a macroeconomic and sectoral environment conducive to economic growth; (b) rehabilitation and development of infrastructure; and (c) development of human resources by providing more efficient social services. Instruments used in supporting these objectives have been adjustment lending (first and second structural adjustment credits (SAL I and SAL II)), buttressed by sector-based rehabilitation and investment projects.

2. In addition to SAL II, which provided a global framework for its support, IDA financed other projects in support of policy and institutional reforms. The Enterprise Development Project assisted in promoting private sector investment in small and medium-scale activities by privatizing and restructuring public enterprises, upgrading the management contract system, and improving the financial performance of several public enterprises. It also improved the performance of the financial sector, partly through the privatization of the Gambia Commercial and Development Bank. Past projects in the transport, utility, and urban sectors promoted private sector activities by improving maintenance and rehabilitation of infrastructure, and by rendering better services with a more efficient use of public resources. Projects in the human resources sector were designed to help the government (a) improve the quality of primary education and raise school enrollment under the Education Sector Project; (b) improve family planning programs (by increasing access to health care and raising the efficiency of health services under the National Health Development Project); and (c) promote women's role in socioeconomic development under the Women in Development Project. In January 2001, a project in the human resources sector was approved to help the government organize a preemptive response to the growing epidemic of immunodeficiency virus (HIV) infection that causes the acquired immunodeficiency syndrome (AIDS).

3. The Country Assistance Strategy (CAS) for The Gambia for fiscal years (FY) 1999-2001, endorsed by the Board on September 10, 1998, is under implementation. By the end of FY 2001, the base-case scenario of the CAS will be attained; with two operations (Economic Reforms Support Operation and Trade Gateway) scheduled for Board approval in FY 2002, the CAS's high-case scenario would be attained.

4. In May 2000, the government and IDA conducted a follow-up of the 1999 Country Portfolio Performance Review (CPPR). The meeting reviewed the action plan of the 1999 CPPR and established progress made since the CPPR.

5. As of March 31, 2001, IDA had approved 26 projects for The Gambia for a total amount of about US\$239.8 million, with an undisbursed amount of about US\$51 million. The current portfolio consists of four projects (Participatory Health/Population/Nutrition, Third Education, Poverty Alleviation \& Municipal Development, and HIV/ADS Rapid Response), totaling US\$68 million. IDA's lending will continue to build around poverty reduction and capacity-building efforts through various operations. In addition to the HTV/AIDS Rapid Response Project that was approved this fiscal year (January 16, 2001), the Capacity Building and Economic Management Project is also scheduled for Board approval this FY 2001, and the Economic Reforms Support Operation and the Trade Gateway Project for FY 2002. 
6. As of March 31,2001, the IFC's portfolio had two investments with a balance of about US\$0.6 million. The current portfolio includes investments under the African Enterprise Facility (AEF) for a medical clinic (Ndebaan) and commercial fishing (Lyefish). The establishment of the AEF has enhanced the IFC's ability to reach smaller businesses, such as those currently in operation in The Gambia.

7. IDA and the IFC will continue to coordinate their respective roles to support development activities in The Gambia. These activities are being enhanced by the IFC's office in Dakar, which also oversees the IFC's activities in The Gambia. 
Summary of Statement of IDA Credits in The Gambia

(As of March 31, 2001; in millions of U.S. dollars)

Projects

22 projects closed

Ongoing Projects:

HIV/AIDS Rapid Response

Participatory Hcalth/Pop./Nutrition

Third Education

Poverty Alleviation and Municipa! Dev.

Total

Repayments

Total due to JDA
Commitment Disbursed Undisbursed

$\begin{array}{lll}171.8 & 172.8 & 0.0\end{array}$

15.0

0.0

15.0

18.0

20.0

15.0

239.8

187.3

51.0

Source: The World Bank Integrated Controller's System - 4/10/01)

The Gambia - Statement of IFC's Held and Disbursed Portfolio (As of March 31, 2001; in millions of U.S. dollars)

\begin{tabular}{|c|c|c|c|c|c|c|c|c|c|}
\hline \multirow[b]{2}{*}{$\begin{array}{c}\text { FY } \\
\text { Approval }\end{array}$} & \multirow[b]{2}{*}{ Company } & \multicolumn{3}{|c|}{ Committed/Held } & \multicolumn{5}{|c|}{ Disbursed } \\
\hline & & Loan & Equity & Quasi & Partic & Loan & Equity & Quasl & Partic \\
\hline 1993 & $\begin{array}{l}\text { AEF Ndebaan } \\
\text { (Medical Clinic) }\end{array}$ & 0.2 & 0.0 & 0.0 & 0.0 & 0.2 & 0.0 & 0.0 & 0.0 \\
\hline \multirow[t]{2}{*}{1994} & $\begin{array}{l}\text { AEF Lyefish } \\
\text { (Commercial Fishing) }\end{array}$ & 0.4 & 0.0 & 0.0 & 0.0 & 0.4 & 0.0 & 0.0 & 0.0 \\
\hline & Total Portfolio & 0.6 & 0.0 & 0.0 & 0.0 & 0.6 & 0.0 & 0.0 & 0.0 \\
\hline Ponding con & itments & 0.0 & 0.0 & 0.0 & 0.0 & & & & \\
\hline
\end{tabular}




\section{The Gambia: Statistical Issues}

1. There are substantial weaknesses in The Gambia's economic and financial statistics, especially in the national accounts, balance of payments, and external debt statistics. Although these weaknesses do not preclude a meaningful assessment of economic policies, the reporting delays and poor quality of some of the data hamper the analysis of recent economic developments. The authorities have recently provided most core data to the Fund in a timely manner. Available data are published in the central bank's quarterly bulletins and the Central Statistics Department's (CSD) publications. The Gambia has volunteered to serve as a General Data Dissemination System (GDDS) pilot country. In November 1999, a STA technical mission helped the authorities to develop the metadata for the GDDS. The metadata are now available in the Fund's Dissemination Standards Bulletin Board (DSBB).

\section{Real sector}

2. Annual national accounts data are available only from the production side and have been produced with a long lag. The breakdown by expenditure category is largely estimated by Fund staff. Reliable data on employment and labor costs are not available. A STA technical expert provided assistance on national accounts in November-December 1998. During 2000, the authorities published documentation on sources and methods used in the current series of GDP by kind of economic activity. Also, the publication of national accounts for fiscal years (FY) 1995/96 and 1996/97 and calendar years 1997 and 1998 will be completed by year's end. For the medium term, the plans for improvements are (a) to move the base year from 1976/77 to a more recent year; (b) to provide estimates of private final consumption; and (c) to change the framework of national accounts from the 1968 System of National Accounts (SNA) to 1993 SNA.

3. A new consumer price index (with a base of July 1994-June 1995) for the low- and middle-income population in the greater Banjul area has been produced, using new weights from the 1992/93 household expenditure survey. To ensure a smooth transition, the CSD will compile both the old and new indices for two years; the old consumer price index (CPD) is based on the 1968/69 household survey. At present, however, the CSD only publishes data using the old weights. During 2001, it will conduct a new household budget survey to update the structure of the CPI index.

\section{Government finance}

4. The authorities provide staff with current information on central government revenue and expenditures. Data on domestic government financing are also available on a monthly basis with a short lag. The three-year rolling public investment program has not been updated for some time, and the execution of public investment needs closer monitoring. The staff was provided with detailed information on foreign-financed extrabudgetary expenditures carried out after the July 1994 military coup. The latest annual data reported for publication in the Government Finance Statistics Yearbook and International Financial Statistics (IFS) correspond to 1993 . 


\section{Monetary data}

5. Monthly balance sheet data of the Central Bank of The Gambia (CBG) are available within two weeks after the end of the reference month, and the monetary survey with a lag of one month. The coverage of banks in the monetary survey is comprehensive, and the banks follow a uniform chart of accounts to report financial data to the CBG. Flash reports of key monetary data are also sent from the banks to the CBG on a weekly basis. Over the past two years, the CBG has introduced several reclassifications to the monetary accounts in an attempt to improve sectorization and coverage, as well as to hamonize the data reported to STA and AFR. A money and banking statistics mission is tentatively scheduled to take place in FY 2001.

\section{Balance of payments}

6. The Gambia's external transactions are characterized by a large volume of activity in the informal sector. For example, the bulk of the reexport trade is unrecorded. Therefore, balance of payment statistics have to be supplemented by estimates of activity in the informal sector. The central bank estimates reexports as a fixed share of total imports. Tourism revenue is estimated based on tourist arrival data from the relevant ministry. Data on private capital flows are poor, mainly because survey data are nonexistent. Data on official grants and loan disbursements and repayments are relatively good. Data on the gross and net international reserves of the central bank are available with a short lag. Coordination and cooperation among the main statistical agencies need to be strengthened to improve the quality of balance of payments statistics; The authorities have begun addressing some of these issues following two STA technical assistance missions in June-July 1999, and in September 2000 .

Based largely on the mission's recommendations, the The CBG established a balance of payments unit equipped with computer resources, and successfully initiated surveys of the banking sector, insurance companies, travel and shipping agents, hotels and foreign embassies. The government has fully computerized its database on the stock of external public debt and the related debt-service obligations, using the Commonwealth Secretariat's debt-reporting and management system with technical assistance from The World Bank. 
The Gambia: Statistical Indicators

(As of July 2001)

\begin{tabular}{|c|c|c|c|c|c|c|c|c|c|c|c|c|}
\hline & $\begin{array}{c}\text { Exchange } \\
\text { Rates }\end{array}$ & $\begin{array}{l}\text { International } \\
\text { Reserves }\end{array}$ & $\begin{array}{c}\text { Reserve } \\
\text { Base } \\
\text { Moncy }\end{array}$ & $\begin{array}{c}\text { Central } \\
\text { Bank } \\
\text { Balance } \\
\text { Sheet } \\
\end{array}$ & $\begin{array}{l}\text { Broad } \\
\text { Money }\end{array}$ & $\begin{array}{c}\text { Interest } \\
\text { Rates }\end{array}$ & $\begin{array}{l}\text { Consumer } \\
\text { Price } \\
\text { Index }\end{array}$ & $\begin{array}{l}\text { Exports } \\
\text { Imports }\end{array}$ & $\begin{array}{l}\text { Current } \\
\text { Account } \\
\text { Balance }\end{array}$ & $\begin{array}{l}\text { Overall } \\
\text { Government } \\
\text { Balance }\end{array}$ & GDP & $\begin{array}{c}\text { External } \\
\text { Debt }\end{array}$ \\
\hline $\begin{array}{l}\text { Date of latest } \\
\text { observation }\end{array}$ & $5 / 2001$ & $3 / 2001$ & $3 / 2001$ & $3 / 2001$ & $3 / 2001$ & $3 / 2001$ & $4 / 2001$ & $12 / 2000$ & $07 / 2000$ & $12 / 2000$ & 2000 & $07 / 2000$ \\
\hline Date received & $4 / 2001$ & $4 / 2001$ & $4 / 2001$ & $4 / 2001$ & $4 / 2001$ & $4 / 2001$ & $2 / 2001$ & $2 / 2001$ & $09 / 2000$ & $2 / 2001$ & $06 / 2000$ & $09 / 2000$ \\
\hline $\begin{array}{l}\text { Frequency of } \\
\text { data } I /\end{array}$ & $M$ & $\mathrm{M}$ & $\mathrm{M}$ & M & M & $\mathrm{M}$ & $\mathrm{Mf}$ & M & $\mathrm{A}$ & $M$ & $\mathrm{~A}$ & $\mathrm{M}$ \\
\hline $\begin{array}{l}\text { Frequency of } \\
\text { reporting } 1 /\end{array}$ & $\mathrm{M}$ & $\mathrm{M}$ & $\mathrm{M}$ & $\mathrm{M}$ & $\mathrm{M}$ & $\mathrm{M}$ & M & M & $\mathrm{A}$ & $\mathrm{M}$ & $\mathrm{A}$ & $\mathrm{M}$ \\
\hline Source of data $2 /$ & A & $\mathrm{A}$ & $\mathrm{A}$ & $\mathrm{A}$ & $\mathrm{A}$ & A & $\mathrm{A}$ & A & $\mathrm{A}$ & $A$ & $A$ & $\mathrm{~A}$ \\
\hline $\begin{array}{l}\text { Mode of } \\
\text { reporting } 37\end{array}$ & C & $\mathrm{C}$ & C & $\mathrm{C}$ & $\mathrm{C}$ & $\mathrm{C}$ & C & $\mathrm{V}$ & $\mathrm{V}$ & $\mathrm{C}, \mathrm{V}$ & $\mathrm{v}$ & $\mathrm{C}, \mathrm{V}$ \\
\hline Confidentiality $4 /$ & $\mathrm{C}$ & $\mathrm{C}$ & $\mathrm{C}$ & $\mathrm{C}$ & $\mathrm{C}$ & $\mathrm{C}$ & $\mathrm{C}$ & $\mathrm{C}$ & C & $\mathrm{D}$ & C & $\mathrm{D}$ \\
\hline $\begin{array}{l}\text { Frequency of } \\
\text { pubilication if }\end{array}$ & D & $M$ & $\mathrm{M}$ & $\mathrm{M}$ & $\mathrm{M}$ & $\mathrm{M}$ & $\mathrm{M}$ & A & A & $\mathrm{M}$ & $\mathrm{A}$ & $M$ \\
\hline
\end{tabular}

L/ $\mathrm{A}=$ annually; $\mathrm{D}$-daily; $\mathrm{M}-$-monthly; $\mathrm{Q}=$ quarterly; and W=-weekly.

2) A=direct reporting by Central Bank of The Gambia, Ministry of Finance, or other official agency.

3/ $\mathrm{C}=$ cable or facsimile; and $\mathrm{V}=$ staff visits.

4/ $\mathrm{C}=$ =unrestricted use; and $\mathrm{D}=$-rescricted until officially published. 


\section{MTERNATIONAL MONETARY FUND \\ Public Information Notice}

EXTERNAL

EDITORIAL DIVISION

ROON IS 7-1200

0433

Public Information Notice (PIN) No. 01/75

EMBARGOED

NOT FOR NEWSWIRE TRANSMISSION

Internationa! Monetary Fund

$70019^{\text {th }}$ Street, NW

Washington, D. C. 20431 USA

UNTIL 6:00 PM WASHINGTON TIME (2200 GMT)

July 26, 2001

\section{IMF Concludes 2001 Article IV Consultation with The Gambia}

On July 13,2001, the Executive Board concluded the Article IV consultation with The Gambia. ${ }^{1}$

\section{Background}

Overall economic performance in The Gambia during 2000 and the early part of 2001 was mixed. The country made important gains in implementing economic and structural reforms, which were supported by the second and thirc annual arrangements under the Poverty Reduction and Growth Facility (PRGF). The economy benefited from robust real GDP growth with low inflation, while important reforms were implemented. They include a further reduction in the external tariff, the rescinding of the problematic preshipment inspection scheme, increases in petroleum product prices, and improvements in budgetary expenditure reporting and control. In October 2000, the government reached an out-of-court settlement with Alimenta (a private Swiss company), under which The Gambia will pay US\$11.4 million by end-July 2001 to the company for the seizure of its property in early 1999 . Accelerated payments to Alimenta, in addition to a payment to commercial banks for overdue crop financing loans and a weak customs revenue performance, contributed to fiscal slippages through March 2001. However, through mid-2001, the government implemented corrective budgetary measures that are expected to bring fiscal performance back on track to a sustainable level of the deficit and contain net government borrowing from the banking system. This outcome should also make it feasible to maintain a prudent monetary policy for the year and permit further improvement in the extemal sector.

\footnotetext{
' Under Article IV of the IMFs Articles of Agreement, the IMF holds bilateral discussions with members, usually every year. A staff team visits the country, collects economic and financial inlomation, and discusses with officials the courtry's economic developments and policies. On return to headquarters, the staff prepares a report, which forms the basis for discussion by the Executive Board. At the conclusion of the discussion, the Managing Director, as Chairman of the Board, summarizes the views of Executive Directors, and this summary is transmitted to the country's authorities. This PIN summarizes the views of the Executive Board as expressed during the July 13, 2001 Executive Board discussion based on the staff report.
} 
In 2000, real GDP growth was 5.6 percent as a result of good rains, which boosted the production of groundnuts and other crops, and a robust performance in the construction sector. The good harvest in 2000 also helped to contain the end-of-period inflation (based on the low-income consumer price index) below the program target of 2 percent.

The external current account deficit (excluding official transfers) is estimated to have widened to 12 percent of GDP in 2000 from 11.5 percent in 1999, as imports recovered from the adverse impact of the preshipment inspection scheme (rescinded in July 2000) while reexports were slowed by cross-border difficulties. The real effective exchange rate of the dalasi depreciated by 4.8 percent during 2000 , contributing to an improvement in the external competitiveness of The Gambia. The overall balance of payments surplus moderated somewhat as private capital inflows declined; gross official reserves increased only slightly to SDR 82.5 million at the end of 2000 , providing the equivalent of about six months of import cover. Effective July 1, 2000, the maximum import tariff rate was reduced from 20 percent to18 percent, and the number of tariff bands was reduced from ten to three.

The overall fiscal deficit (excluding grants) was reduced to 3.6 percent of GDP in 2000 (virtually in line with the program target) from 4.75 percent in 1999 as a revenue shortiall, mainly in customs receipts, and a slight overrun in recurrent expenditure were largely offset by lower development expenditure because of lower external financing. The deficit including grants, at 1.4 percent of GDP, slightly exceeded the program target but was not as high as the level of 3.5 percent reached in 1999 . Total government revenue increased as a ratio to GDP to 18.5 percent from 17.75 percent in 1999; recurrent expenditure as a share of GDP increased to 18.3 percent in 2000 from about 18 percent in 1999.

Monetary policy was largely accommodating as domestic credit expansion, both to the government and the private sector, exceeded the targets through end-March 2001. During 2000 , broad money grew by 35 percent, considerably above the program target; it moderated to 14 percent at end-March 2001. Reserve money, mainly currency outside banks, also exceeded the program target. The treasury bill rate declined from 12.5 percent in December 1999 to 12 percent by December 2000; however, the trend was reversed, and the rate increased to 12.5 percent in February 2001.

A number of reforms were implemented to strengthen budgetary performance, including the identification of, and measures to pay off, government arrears and the introduction of reporting and control safeguards on all government expenditure. The preshipment inspection schemewhose flawed introduction and implementation resulted in significant loss of revenue- was abolished effective July 2000 . In March 2001 , Alimenta withdrew its property dispute with the government from the International Center for the Settlement of Investment Disputes after the government had paid about US $\$ 6.5$ million and provided a bank guarantee for the outstanding balance of US\$5 million.

The government made significant progress in implementing the PRSP process, including the completion of a detailed work agenda to complete the full PRSP by end-2001. In May 2001. the government introduced a comprehensive framework to monitor poverty-reducing expenditure, including expenditure funded from debt relief under the enhanced HIPC Initiative. 
It has also continued to make significant progress in preparing several pieces of legislation, which are awaiting parliamentary approval, aimed at strengthening the supervisory and regulatory role of the central bank in the financial sector, establishing an updated legal basis for business incentives and privatization, and enhancing competition in the private sector.

\section{Executive Board Assessment}

The Directors noted that The Gambia's economic performance during 2000 and the first half of 2001 has been mixed. On the positive side, real GDP growth was robust, inflation remained low, and progress was made in the PRSP process. At the same time, Directors expressed concern about slippages in fiscal policy, which stemmed partly from efforts to resolve the Alimenta property dispute but also from shortfalls in customs revenue, and delays in implementing some structural reforms. They commended the authorities for implementing corrective measures and noted that, with the benefit of technical assistance, the authorities should be in a position to regain the momentum of structural reform.

Directors considered that the revised economic program for the balance of 2001 appropriately aims at strengthening policies in areas where slippages have occurred, and at deepening structural reforms to improve the environment for private sector activity and to enhance the delivery and monitoring of public services. Such an approach is essential to restore macroeconomic stability and contribute to a durable reduction in poverty.

On governance issues, Directors commended the authorities for the ongoing action to settle the property dispute with Alimenta. They encouraged the authorities to implement governance-strengthening measures under the PRSP by enhancing transparency and accountability in public resource management, including timely auditing of public accounts and adoption of the medium-term expenditure framework. They welcomed the central bank's initiatives to enact an anti-money laundering law and improve corporate governance of banks.

Directors stressed that fiscal performance needs to be consistent with the goal of maintaining a sustainable level of government domestic debt. On the revenue side, the improvement in customs administration, the increase in petroleum prices, and the curtailment of customs duty exemptions remain critical, especially in light of the recent external tariff reductions. Directors also stressed the need to rein in government expenditure in an election year, with particular emphasis on the wage bill. They also urged the authorities to continue building capacity in public expenditure management. They welcomed efforts to improve expenditure reporting and control as well as debt management, along with closure of the public accounts and the undertaking of public expenditure reviews in key sectors. They also commended the thrust to intensify collaboration with donors, which would ensure timely access to technical assistance support in these and other areas.

Directors underscored the importance of prudent monetary policy to maintain the low level of inflation. They noted that consolidation and deepening of reforms in the financial sector, including automation of trading in treasury bills and increased interest rate flexibility, would facilitate monetary control. They stressed also the need to maintain strong supervision of financial institutions, particularly the microfinance institutions. 
The current level of the exchange rate was considered to be appropriate in the context of the prudent financial policies currently proposed, and the commitment to keep the rate sufficiently flexible so as to maintain the country's external competitiveness was welcomed. Directors commended the progress in reducing and rationalizing import tariffs.

Directors urged the authorities to expedite the implementation of structural reforms, with emphasis on improving business legislation and privatization of public enterprises and port services. They underscored the need for timely reforms in the marketing arrangement for groundnuts, including the privatization of the Alimenta assets in an open and transparent manner. These reforms would be crucial for eliminating direct government involvement in financing groundnut marketing.

Directors considered data quality and provision to be adequate for surveillance and program monitoring. They noted progress made in improving economic and financial data and encouraged the authorities to continue their efforts in this regard with timely technical assistance.

Public Information Notices (PINs) are issued, (a) at the request of a member country, following the conclusion of the Article IV consultation for countries seeking to make known the views of the IMF to the pubiic. This action is intended to strengthen IMF surveillance over the economic policies of member countries by increasing the transparency of the IMF's assessment of these policies; and (b) following policy discussions in the Executive Board at the decision of the Board. 
The Gambia: Selected Econoraic and Financial Indjcators, 1995/96-2001 $1 /$ $1995 / 96 \quad 1996 / 97 \quad 1997 \quad 1998 \quad 1999 \quad 2000 \quad 2001$

Est. Prel. Proj.

(Annual percentage changes)

Domestic economy

Real GDP

Nominal GDP

GDP deflator

Consumer price index (period average)

Groundnut production (in thousand of metric tons)

$\begin{array}{llllll}0.8 & 4.9 & 3.5 & 6.4 & 5.6 & 5.7\end{array}$

$\begin{array}{rrrrrrr}5.3 & 0.8 & 4.9 & 3.5 & 6.4 & 5.6 & 5.7 \\ 8.8 & 5.3 & 7.7 & 6.1 & 11.0 & 9.5 & 10.0 \\ 3.3 & 4.5 & 2.6 & 2.1 & 4.4 & 3.8 & 4.0 \\ 4.8 & 2.1 & 2.8 & 1.1 & 3.8 & 0.9 & 4.0 \\ 75.2 & 45.8 & 78.1 & 73.5 & 123.0 & 138.0 & 149.0\end{array}$

Gross fixed investment

\section{Government}

Private

Gross domestic savings

Goss national savings

Govemment

Private

Financial variables

Government revenues

Current expenditures

Overall fiscal baiance, excluding grants 2 t

Overall fiscal balance, including grants $2 t$

Basic primary balance

Current balance

Change in broad money (in percent)

Exports, f.o.b.

Imports, f.o.b.

Current account balance

Excluding official transfers

Including official transfers

Current account balance

Excluding official transfers $3 /$

Including official transfers $3 f$

Overall balance of payments

Gross official reserves (end of period)

In months of imports, c.i.f.

External debt service 4/

External debi outstanding

Exchange rate (dalasis per SDR)
(In percent of GDP)

\begin{tabular}{rrrrrrr}
\multicolumn{8}{c}{ (In percent of GDP) } \\
23.4 & 19.3 & 17.2 & 18.4 & 17.8 & 17.3 & 17.9 \\
12.9 & 12.7 & 8.4 & 5.9 & 5.3 & 4.6 & 4.9 \\
10.5 & 6.6 & 8.8 & 12.5 & 12.5 & 12.7 & 13.0 \\
2.9 & 6.0 & 7.1 & 7.5 & 7.9 & 4.9 & 5.6 \\
10.0 & 12.6 & 13.5 & 15.3 & 13.5 & 12.7 & 15.3 \\
8.0 & 8.2 & 8.4 & 9.3 & 7.1 & 7.6 & 9.5 \\
2.0 & 4.4 & 5.1 & 6.1 & 6.4 & 5.1 & 5.8
\end{tabular}

(In percent of GDP, unless otherwise specified)

$\begin{array}{rrrrrrr}17.7 & 19.4 & 19.1 & 18.8 & 17.8 & 18.5 & 19.2 \\ 17.6 & 18.5 & 19.1 & 17.9 & 17.9 & 18.3 & 20.1 \\ -12.1 & -11.4 & -7.8 & -4.4 & -4.8 & -3.6 & -3.9 \\ -9.9 & -9.7 & -6.5 & -2.4 & -3.5 & -1.4 & -1.0 \\ 3.6 & 5.1 & 4.9 & 5.7 & 4.6 & 4.6 & 3.7 \\ 0.1 & 0.9 & 0.1 & 0.7 & -0.2 & 1.2 & -0.9 \\ 8.8 & 16.7 & 22.3 & 10.2 & 12.1 & 34.3 & 7.9\end{array}$

(In millions of SDRs, tnless otherwise indicated)

$\begin{array}{rrrrrrr}80.3 & 78.1 & 78.8 & 95.8 & 87.9 & 95.9 & 109.1 \\ -139.0 & -131.0 & -127.9 & -152.7 & -141.5 & -145.8 & -157.0 \\ & & & & & & \\ -53.4 & -36.3 & -31.4 & -35.6 & -36.4 & -38.5 & -34.4 \\ -35.6 & -19.0 & -11.0 & -9.3 & -13.5 & -14.7 & -7.4 \\ & & & & & & \\ -20.1 & -12.8 & -10.6 & -11.6 & -11.5 & -12.0 & -11.8 \\ -13.4 & -6.7 & -3.7 & -3.0 & -4.3 & -4.6 & -2.6 \\ 12.4 & 5.2 & 4.7 & 7.1 & 2.3 & 1.2 & -11.2 \\ 70.1 & 70.4 & 69.6 & 75.4 & 78.1 & 82.5 & 80.9 \\ 5.2 & 5.5 & 5.6 & 5.1 & 5.8 & 5.9 & 5.3 \\ 16.2 & 13.1 & 13.5 & 11.4 & 11.4 & 8.5 & 15.6 \\ 111.1 & 107.0 & 104.4 & 103.3 & 98.4 & 100.1 & 108.9 \\ 14.3 & 14.1 & 14.0 & 14.4 & 15.6 & 16.8 & \ldots\end{array}$

Sources: The Gambian authorities; and IMF staff estimates and projections.

1/ Until 1996/97, fiscal years (July-June); from 1997, calendar years.

2/ On a commitment basis.

3/ In percent of GDP.

4/ In percent of exports and travel income. 


\section{Statement by Cyrus D.R. Rustomjee, Executive Director for The Gambia July 13, 2001}

\section{Introduction}

A renewed effort since mid-1998, in the context of a three-year Poverty Reduction and Growth Facility (PRGF) arrangement, has helped The Gambia to make important advances in many areas. Real GDP grew by an average of 5.2 percent during 1998-2000, compared with an average of 1 percent during 1994-1996. Inflation remained below 3 percent during the same period, compared with 70.4 percent in 1986 and many years of double-digit rates thereafter, largely on account of tight macroeconomic management and a relative stability of the exchange rate. Fiscal policy has been considerably tightened as the overall deficit, excluding grants, has been reduced from around 8 percent of GDP in 1997 to 3.6 percent in 2000 . The magnitude of the adjustment, which meant more than halving of the deficit in the course of three years, called for an extraordinary effort on the part of the authorities

Moreover, the external current account deficit has generally followed a narrowing trend, with the level at end-2000 being two-and - $-\mathrm{a}$-half times less than what it was almost a decade ago. This has led to a buildup in official reserves. Several important steps have also been taken to improve the soundness of the banking system and enhance financial sector competition. In the area of trade, the maximum duty rate has been significantly reduced from 90 percent in 1998 to 18 percent in August 2000, while the number of tariff bands has been even more significantly reduced from over 30 to only 3 , making The Gambia's the most liberalized trade regime in the region. Moreover, business-related legislation and regulations have been modernized to promote private sector growth. Governance improvement has been on the authorities' priority agenda since the adoption of the Governance Policy in 1999.

These achievements have to be seen against a background in which staying the course has not been easy. Regional instability and cross-border difficulties have adversely affected the reexport trade and tourism, which used to be the main sources of budgetary revenue and foreign exchange. This has been compounded by the decline in foreign assistance and a sizable refugee problem. Moreover, the limited natural resources and a weak institutional capacity have been additional constraints. The Gambia is also a country where nearly 70 percent of the population live in poverty and over 50 percent in extreme poverty, and where youth unemployment is very high, necessitating higher expenditures than were actually committed. The large burden of external debt has also been thwarting the authorities' efforts at strengthening the adjustment process. My authorities are therefore hopeful that the Board will be able to duly appreciate the adjustment effort, including in the fiscal area, that has been demonstrated. In the years ahead, they are firmly committed to continue with the reforms, in view of the increasing awareness in The Gambia that bold and comprehensive policy reforms are indispensable to attaining macroeconomic stability and high sustainable growth, which are critical to meeting the pressing need of alleviating poverty. 


\section{Progress Under the Third Annual Program}

During the first half of the period under the third annual arrangement which runs from October 1, 2000 to September 30,2001, with the benefit of favourable weather conditions, real GDP continued to grow strongly, while inflation remained low. The authorities also continued to implement a number of important structural reforms, notably in the fiscal area, including those aimed at enhancing expenditure reporting and control procedures, eliminating government's cross arrears with public enterprises, improving tax administration and compilation of customs data, and the closing of the government accounts for 1992-97. Key pieces of legislation that focused on the promotion of business efficiency and the private sector were also enacted.

Notwithstanding these achievements, however, the authorities had difficulty in implementing the fiscal program. A shortfall in customs receipts largely contributed to government's recourse to domestic borrowing in order to finance important expenditures. Under the terms of the settlement of the property dispute between Alimenta - a Swiss private entity which is the parent company of the Gambia Groundnut Corporation (GGC) -and the government reached in October 2000 , the authorities paid the initial installment to Alimenta in late December in an amount that was in excess of the expected payment, and also made a further early payment in February 2001. The government also made payments to three commercial banks in February 2001 to cover the nonperforming loans that had financed the 1999/2000 groundnut crop. These led to slippages in the budget through end-March 2001 and resulted in the nonobservance of three end-March performance criteria related to net bank credit to the central government, net domestic assets of the central bank, and the basic primary balance of the central government. These three criteria are interrelated and their number has therefore to be seen in that light. The accelerated payment to Alimenta, together with a substantial sale of foreign exchange to meet the prevailing demand, was also responsible for the breach on the performance criterion as regards the floor on net international reserves. It is to be noted, therefore, that the nonobservance of all four performance criteria has been largely on account of a single episode pertaining to one form of expense, the payment to Alimenta, and it would be important to view the extent of the fiscal slippage in that context.

In the past, the $\mathrm{GGC}$ property dispute had constituted one of the most important issues of concern to donors and the investment community. It had also represented a test of government commitment to economic reform in general and to improving governance in particular. In view of that, the authorities have considered the resolution of the dispute as one of their top economic priorities to restore business confidence and garner international support for their important reform efforts. The accelerated payments to Alimenta have proven beneficial with Alimenta withdrawing its case from arbitration at the International Centre for Settlement of Investment Disputes (ISCD) in March 2001. Moreover, as a result of these payments, it has been possible to reduce the interest and other charges on outstanding balances payable to Alimenta, because, under the settlement agreement, interest is payable on any outstanding balances as from January 1, 2001. When Alimenta has been paid in full, the final payment being slated for end-July 2001, its two groundnut-processing plants and a number of barges will return to the government and thereafter be sold to 
different marketing firms in order to increase competition and benefit farmers as part of broader reforms to improve the groundnut sector.

The government's payment to the commercial banks for the outstanding crop financing loans was also of importance. It has helped to avert a major deterioration in the financial position of these banks.

In this connection, it may be important to point out that, quarterly monitoring, particularly when there are several performance criteria and benchmarks, is bound to result in instances where it would be difficult to avoid temporary aberrations or deviations from the intended path. In the case of The Gambia, limitations in institutional capacity also compound the problem. There were some temporary deviations in the past, such as in late 1999 and early 2000; but the Gambian authorities were quick to respond and succeeded in placing the program back on track. The authorities' response to address the present slippages was also prompt and is very much expected to help strengthen the policies and facilitate their implementation in the period ahead.

\section{Policy Course in the Remainder of 2001}

The prospects for the remainder of 2001 appear to be bright. Agricultural production is expected to pick up; the anticipated marketing reforms, following the settlement of the Alimenta problem, should have a positive impact on the production of groundnuts which is also an important export crop. Inflation is expected to remain low at around 3.5 percent, despite the depreciation of the dalasi and the increase in domestic petroleum prices. The reexport trade and tourism are expected to continue recovering and, together with the further expansion in groundnut production, are likely to facilitate the narrowing of the current account deficit and contribute toward a further buildup of official reserves.

In the fiscal area, despite higher interest payments and spending pressures associated with the upcoming elections, the fiscal deficit will be contained at around 3.9 percent of GDP, compared with 3.6 percent in 2000 and 4.8 percent in 1999 . The recent measures to improve customs administration and increase petroleum prices have helped to mitigate the short-term impact of the fiscal slippages discussed above. These measures, together with the ongoing strengthening of expenditure reporting and control and steps to further improve tax collection, will have an impact of also allowing a significant reduction in the fiscal deficit starting in 2002, while facilitating a substantial decline in the domestic debt and freeing of resources for poverty reduction.

Monetary policy will aim at maintaining low inflation and strengthening external reserves. Accordingly, sales of securities will enable the central bank to moderate the growth of broad money from around 35 percent in 2000 to 8 percent by end-2001. Already, for the 12-month period ended March 2001, broad money growth has been reduced to 14 percent. Exchange rate flexibility will continue to be promoted, consistent with a further buildup of foreign reserves. The authorities will continue to pursue reforms aimed at further enhancing 
competition among banks, strengthening financial sector supervision, and improving the operation of the money market.

As part of other measures in the area of structural reform, an accounting framework to track poverty-reducing expenditures, an aspect for which the authorities have also requested waiver for nonobservance, was established in May 2001. Parliament is expected to approve a Regulatory Bill, with the aim of establishing an agency to regulate utilities that are to be privatized in the future. The government will also take measures to discourage a further accumulation of payment arrears by public enterprises. Implementing reforms in groundnut marketing will remain a priority, while efforts to further improve governance will be strengthened. The authorities continue to be committed to a liberal trade regime.

The corrective measures taken in good faith to address the slippages and the authorities' determination to continue with reforms should provide the needed assurance that, with generous external support, The Gambia can successfully meet the various challenges in the period ahead and over the medium term. I would therefore urge the Board to support the authorities' request for waivers as regards the nonobservance of some of the performance criteria and to complete this first review under the third annual PRGF arrangement.

\section{The PRSP Process}

Broad-based efforts have continued to lay the groundwork for the completion of a full PRSP Despite the delays in holding the Roundtable meeting, donors have continued to support the PRSP process. As also indicated in the staff report, an outline of the PRSP was circulated in May 2001 for comments, and drafting should start by late summer. Already, the authorities have made good progress with education and health reforms which, together with establishment of a mechanism to track poverty-reducing expenditures, the privatization of Alimenta assets, and the implementation of the PRSP, are triggers for the enhanced HIPC Initiative floating completion point. 